\title{
MEDICINA: A CIÊNCIA DA VIDA VOLUME II
}

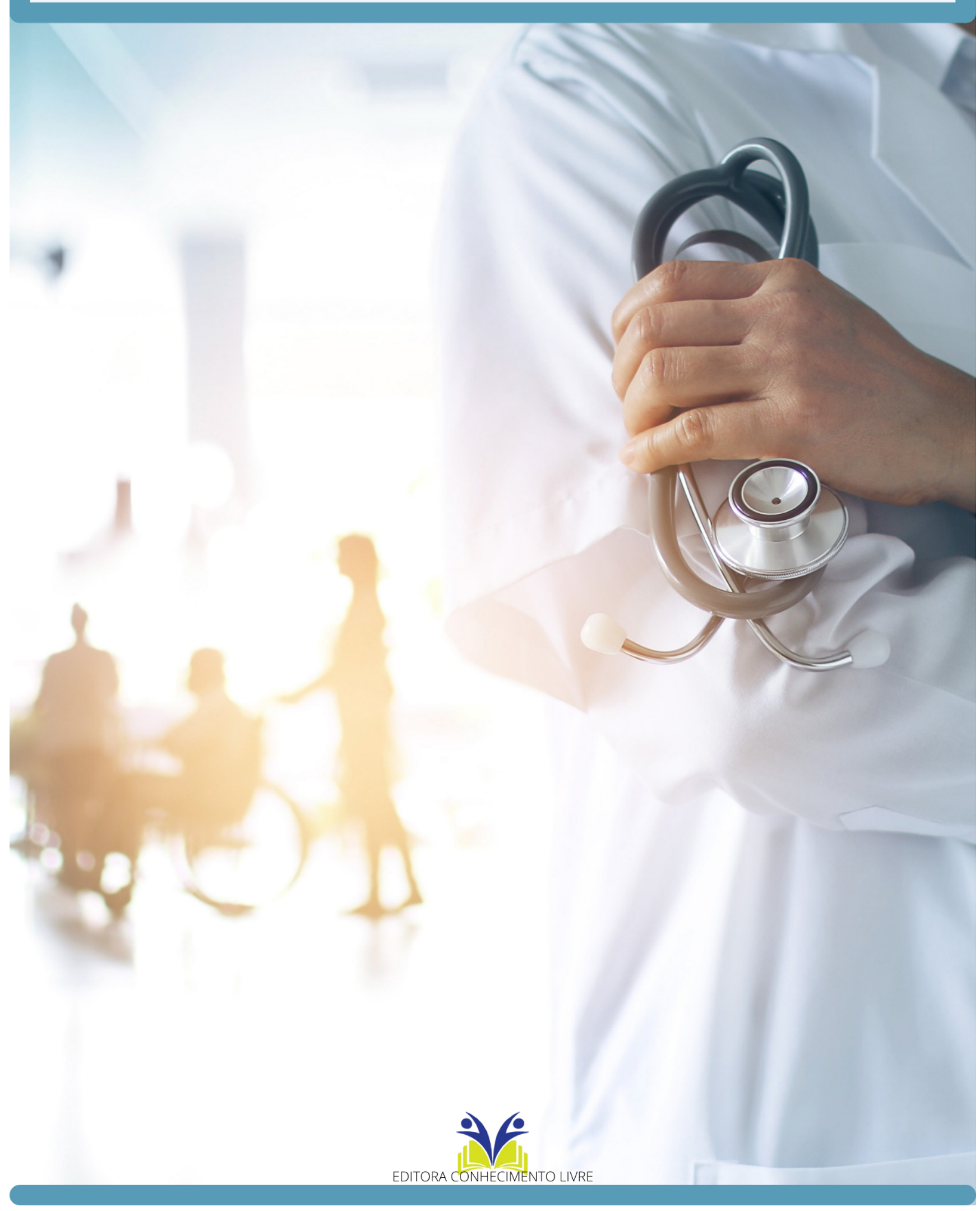


Frederico Celestino Barbosa

Medicina: a ciência da vida

$1^{\text {a }}$ ed.

Piracanjuba-GO

Editora Conhecimento Livre

Piracanjuba-GO 
$1^{\mathrm{a}} \mathrm{ed}$

\section{Dados Internacionais de Catalogação na Publicação (CIP)}

Barbosa, Frederico Celestino
B238M Medicina: a ciência da vida

/ Frederico Celestino Barbosa. - Piracanjuba-GO

Editora Conhecimento Livre, 2021

$101 \mathrm{f} .:$ il

DOI: $10.37423 / 2021$. edcl306

ISBN: 978-65-89955-57-3

Modo de acesso: World Wide Web

Incluir Bibliografia

1. saúde 2. prevenção 3. cura 4. tratamento 5. diagnóstico I. Barbosa, Frederico Celestino II. Título

CDU: 610

https://doi.org/10.37423/2021.edcl306

O conteúdo dos artigos e sua correção ortográfica são de responsabilidade exclusiva dos seus respectivos autores. 


\title{
EDITORA CONHECIMENTO LIVRE
}

\section{Corpo Editorial}

\author{
Dr. João Luís Ribeiro Ulhôa \\ Dra. Eyde Cristianne Saraiva-Bonatto \\ Dr. Anderson Reis de Sousa \\ MSc. Frederico Celestino Barbosa \\ MSc. Carlos Eduardo de Oliveira Gontijo
}

$\underline{\text { MSc. Plínio Ferreira Pires }}$

Editora Conhecimento Livre

Piracanjuba-GO 


\section{SUMÁRIO}

CAPÍTULO 1 6

SÍNDROME DE BURNOUT DURANTE E PÓS-PANDEMIA DA COVID-19 EM PROFISSIONAIS

DA UNIDADE DE SAÚDE DA FAMÍLIA E ESTRATÉGIAS DE PROMOÇÃO DE SAÚDE

Rafael Freitas Silva Peralta

Leilany Marins Andrino

Isabella Camin Pena

Izabella Araujo de Oliveira

Dyego Douglas Dias Silva

Vítor Augusto Ferreira Braga

DOI 10.37423/210804583

CAPÍTULO 2

PREVALÊNCIA DAS DOENÇAS CRÔNICAS NÃO TRANSMISSÍVEIS NA ÁREA DE

ABRANGÊNCIA DA UAPS NOVA FLORESTA: UM ENFOQUE NO DIABETES E HIPERTENSÃO

Vinicius Luiz da Silva Pena

DOI 10.37423/210804591

CAPÍTULO 3 36

ESCALA DE COMA DE GLASGOW COM RESPOSTA PUPILAR (ECG-P) E SUA RELAÇÃO COM O PROGNÓSTICO DE PACIENTES COM TCE: UMA REVISÃO DA LITERATURA

BÁRBARA ANDRESSA SILVA FERREIRA

AMANDA ROCHA DORNELES

FERNANDA BEATRIZ GALVANI

GUILHERME CINCINATO DE ALMEIDA

ISADORA ALMEIDA COUTO

LOUISE OLIVEIRA PEREIRA

LUANA ASSUNÇÃO FIALHO

RAFAEL PEREIRA DE AMORIM

TIAGO GUIMARÃES REIS

NATALIA DE FATIMA GONÇALVES AMANCIO

DOI 10.37423/210804596

CAPÍTULO 4

DISTOCIA DE OMBRO E A PRÁTICA DA ASSISTÊNCIA HUMANIZADA AO PARTO

Lia Francisco Paiva Baía

Victória Eler Fava

Ariana Pinheiro Caldas

Camila Soares de Almeida

Marcelo de Figueiredo Murta

Maria Alice Boareto Freitas

DOI 10.37423/210804602 
PERFIL E ESTADO DE SAÚDE PÓS-PARTO DOS NASCIDOS VIVOS DE ACORDO COM A

FAIXA ETÁRIA MATERNA EM UM HOSPITAL DE REFERÊNCIA EM FORTALEZA-CE

Jocileide Sales Campos

Amanda Teixeira de Aguiar

Bruna Danielle Paula da Ponte

Marina Costa Campos

Mayara Carvalho Fortes

Juliana Guerreiro Mota

Mariana Ribeiro Moura

Carolina de Paiva Farias

Ana Manuela Diógenes Teixeira

Renata Santos Almeida

DOI 10.37423/210804617

CAPÍTULO 6

AVALIAÇÃO DA PREVALÊNCIA DA DOENÇA PERIODONTAL EM PACIENTES COM DOENÇA

RENAL CRÔNICA SOB TRATAMENTO DE HEMODIÁLISE

Jairton Costa Filho

Thaiane Caroline Nascimento Costa

DOI 10.37423/210804639 


\section{Capítulo 1}

d.

SÍNDROME DE BURNOUT DURANTE E PÓS-

PANDEMIA DA COVID-19 EM PROFISSIONAIS DA

\section{UNIDADE DE SAÚDE DA FAMÍLIA E ESTRATÉGIAS DE PROMOÇÃO DE SAÚDE}

Rafael Freitas Silva Peralta

Leilany Marins Andrino

Isabella Camin Pena

Izabella Araujo de Oliveira

Dyego Douglas Dias Silva

Vítor Augusto Ferreira Braga
Centro universitário de Patos de Minas UNIPAM

Centro universitário de Patos de Minas UNIPAM

Centro universitário de Patos de Minas UNIPAM

Centro universitário de Patos de Minas UNIPAM

Centro universitário de Patos de Minas UNIPAM

Centro universitário de Patos de Minas UNIPAM 
Resumo: As transformações da sociedade contemporânea ocasionam em alterações nas relações de trabalho. Diante disso, o trabalhador necessita grande esforço físico e psíquico que muitas vezes, ultrapassam a sua capacidade, se submetendo às situações laborais prejudiciais à saúde. A Síndrome de Burnout (SB) é uma patologia decorrente de excessivos e prolongados níveis de estresse (tensão) no ambiente de trabalho, a qual leva a um importante prejuízo do estado físico e mental. Em dezembro de 2019 uma série de casos de infecção respiratória por um agente desconhecido foi retratada em Wuhan, China. Doença posteriormente denominada Covid-19 foi declarada pela Organização Mundial da Saúde (OMS) como pandemia em março de 2020. Os profissionais de saúde estão na linha de frente do cenário pandêmico e estão expostos a condições potencialmente agravantes de seu estado de saúde como preocupação, estresse e mudança do cenário de trabalho. O presente estudo tem como objetivo identificar a presença da SB nos profissionais da Unidade de Saúde da Família (USF) Itamarati em Patos de Minas, correlacionando com a pandemia. Trata-se de uma pesquisa de campo, descritiva exploratória com abordagem quantitativa utilizando o Inventário de Burnout De Maslach (MBI-HSS) com a autorização do Comitê de Ética (CEP). Seguida de uma intervenção para implementar estratégias de prevenção da SB na USF. Os participantes da pesquisa serão os profissionais de saúde da USF. A análise dos dados será feita pela estatística descritiva de acordo com o questionário e os dados serão apresentados em tabelas e gráficos. Em valores absolutos e relativos.

Palavras chave: Atenção Primária à Saúde. COVID-19. Esgotamento Profissional. 


\section{INTRODUÇÃO}

As transformações da sociedade contemporânea ocasionam alterações nas relações de trabalho. 0 consumismo, o individualismo, a competitividade e a agressividade são algumas das características do trabalho vivenciado no cenário atual. Esse ambiente exige grande esforço físico e psíquico que muitas vezes, ultrapassam a capacidade do trabalhador, o qual se submete às situações laborais prejudiciais à saúde, para permanecer no emprego (REZENDE; BORGES; FROTA, 2012).

Frente a essa atual conjuntura, novas exigências de qualificação e competências do trabalhador são necessárias. Como resultado, novas enfermidades como os transtornos mentais, merecem destaque. Dentre eles encontra-se a Síndrome de Burnout (SB) (PÊGO; PÊGO, 2016).

O termo "burnout" é definido como algo que deixou de funcionar conseguinte a absoluta falta de energia. A síndrome de burnout é uma patologia decorrente de excessivos e prolongados níveis de estresse (tensão) no ambiente de trabalho, a qual leva a um importante prejuízo do estado físico e mental (TRIGO; TENG; HALLAK, 2007).

Em dezembro de 2019 uma série de casos de infecção respiratória por um agente desconhecido foi retratada em Wuhan, China (ZHU et al., 2020). Posteriormente denominada Covid-19 a doença disseminou-se com progressão mundial, de modo que em 30 de janeiro de 2020 a OMS declarou que a doença constituía uma Emergência de Saúde Pública de Importância Internacional (ESPII) (WORLD HEALTH ORGANIZATION, 2020a) e em março de 2020, uma pandemia (WORLD HEALTH ORGANIZATION, 2020b).

Desde então, a vida cotidiana dos profissionais de saúde mudou profundamente, a economia entrou em recessão e muitas redes tradicionais de segurança social, econômica e de saúde pública foram submetidas a pressões sem precedentes. O cenário pandêmico tornou-se um ambiente propício para o desenvolvimento da síndrome de burnout associada ou não a ansiedade e depressão (HUMEREZ; OHL; SILVA, 2020).

Desse modo, os profissionais de saúde participantes do atual sistema estão expostos a condições potencialmente agravantes de seu estado de saúde, devido a várias causas - dentre elas, a preocupação em propagar a infecção entre seus amigos e familiares e o rearranjo da organização laboral, com a sobrecarga de alguns profissionais, devido ao afastamento dos colegas que contraíram a doença. A submissão ao ambiente de risco somado aos fatores estressantes contribui para o desenvolvimento da SB (VELOZ et al., 2020). 
Tendo em vista tais fatores, a pandemia e suas consequentes mudanças no ambiente laboral, contribuem para o aumento da prevalência da SB nos ambientes de assistência à saúde. Desse modo, verificarmos a importância de investigar a interferência da pandemia do COVID 19 na saúde do trabalhador, analisando a sobrecarga pessoal e profissional e o desenvolvimento da SB. Além de também, oferecer formas de manejo da SB, com rodas de conversa e auriculoterapia.

\section{JUSTIFICATIVA}

O atual cenário pandêmico vivenciado pelos profissionais de saúde trouxe diversas modificações profissionais e sociais. Nesse âmbito é importante verificar a mudança de rotina dos profissionais como um potencial estressor desencadeante da síndrome de burnout, tendo em vista que as modificações profissionais são fatores de risco para tal transtorno. Além disso, é necessário implementar medidas preventivas relacionadas a SB, visando melhor qualidade de vida dos profissionais.

\section{OBJETIVOS}

\subsection{OBJETIVO GERAL}

- Identificar a presença de Síndrome de Burnout nos profissionais da Unidade de Saúde da Família (USF).

\subsection{OBJETIVOS ESPECÍFICOS}

- Caracterizar as manifestações clínicas Síndrome de Burnout nos profissionais da USF;

- Caracterizar o perfil demográfico, social e clínico dos profissionais da USF;

- Verificar a prevalência da Síndrome de Burnout nos trabalhadores da USF;

- Relacionar a pandemia com situações de estresse dos profissionais da USF;

- Implantar estratégias de prevenção da Síndrome de Burnout na USF.

\section{REVISÃO BIBLIOGRÁFICA}

O trabalho é parte da natureza humana e é a partir dele que o homem constrói sua identidade subjetiva e, também, a sociedade ao qual pertence. Porém, essa atividade pode ocupar grande parcela 
do tempo dos indivíduos, podendo causar em suas vidas, consequências negativas, como insatisfação e exaustão (PÊGO; PÊGO, 2016).

A Síndrome de Burnout é constituída por uma reação à tensão emocional crônica, ocasionada em contexto laboral, principalmente naqueles trabalhadores que tem contato direto e frequente com outros seres humanos (TEIXERA; SILVA; MEDEIROS, 2010). A palavra Burnout vem de um jargão inglês, definido como aquilo que deixou de funcionar por absoluta falta de energia, ou seja, algo que chegou ao seu limite, trazendo consigo, enorme prejuízo, tanto físico como mental (TRIGO; TENG; HALLAK, 2007).

Os principais sintomas da síndrome são: exaustão emocional e distanciamento afetivo. No primeiro, sentimentos de desesperança, solidão, depressão, raiva, impaciência, irritabilidade, tensão, diminuição de empatia, aumento da suscetibilidade para doenças, cefaleia, náuseas, tensão muscular, dor lombar ou cervical e distúrbios do sono podem acometer o indivíduo. Já o distanciamento afetivo ocasiona sensação de alienação em relação aos outros, sendo a presença destes muitas vezes desagradável e não desejada (CÂNDIDO; SOUZA, 2017).

O Brasil e o mundo tem enfrentado uma grave pandemia ocasionada por uma doença infecciosa, que tem como agente etiológico o novo coronavírus (SARS-CoV-2). A doença chamada COVID-19 é potencialmente fatal e altamente transmissível por gotículas ou contato direto, taxa que se eleva se o ambiente for fechado. Dessa maneira, os profissionais de saúde têm enorme suscetibilidade à infecção, pois precisam ter contato direto com os pacientes (TEIXERA et al., 2020).

Nesse contexto, tornou-se evidente o desafio que esses profissionais necessitam enfrentar diariamente para manter sua própria saúde mental e física. Alguns aspectos podem ser apontados como fatores de estresse, como: falta de Equipamentos de Proteção Individual (EPI), falta de conhecimento e de treinamento para atender tal população específica; nível de complexidade e gravidade dos pacientes, inexistência de um tratamento específico e eficaz para a doença; desgaste causado pela impossibilidade de acolher a demanda de pacientes; necessidade em lidar com o volume aumentado de óbitos, inclusive de familiares e colegas de trabalho (SOUSA JÚNIOR et al., 2020). Além disso, muitos profissionais estão preocupados com sua segurança pessoal e com medo de transmitir a doença para seus familiares (COVID-19, 2020).

Nesse contexto, muitos profissionais de saúde são afastados do trabalho devido aos sintomas de COVID-19 ou por fazerem parte de algum grupo de risco (MEIRA et al., 2020). Com o aumento da 
demanda de serviço e a diminuição de funcionários disponíveis a sobrecarga de trabalho é inevitável. De acordo com esse estudo, as mulheres são as que mais ocupam os cargos de saúde, ficando exposta ao ambiente estressante de pandemia, sem contar a carga de cuidado doméstico, que a maioria das mulheres carregam sozinhas, deixando-as mais vulneráveis ao adoecimento psíquico. Além disso, foi constatado que a maioria dos trabalhadores têm mais de 30 anos de idade, sendo mais sujeitos a terem comorbidades e fatores de risco para contrair o COVID-19.

No final do mês de março, foi decretada a medida provisória no 927 que alterou o regime de trabalho dos profissionais da saúde, permitindo plantões de 24 horas com apenas 12 horas de descanso, antes era 24 horas de trabalho e 24 horas de descanso. A medida deixou os profissionais mais expostos a doença e mais sujeitos a exaustão física, psíquica e emocional. Essa medida foi revogada em 19 de julho de 2020 (BRASIL, 2020).

Nesse sentido, o PEBMED fez um estudo transversal por meio de um questionário online. Dos 3.613 participantes, 2.932 eram médicos, 457 enfermeiros e 224 técnicos de enfermagem, foi utilizada a escala Oldenburg Burnout Inventory (OLBI), tendo como resultado a prevalência da síndrome de 78\% entre os respondentes, sendo $79 \%$ entre médicos, $74 \%$ entre enfermeiros e $64 \%$ entre técnicos de enfermagem. A pesquisa, no entanto, teve alguns vieses, como método único, recebendo as respostas por uma mesma ferramenta, amostra mais próxima da realidade da região sudeste do Brasil, onde a pandemia estava mais avançada no período da pesquisa (BARRETO, 2020).

As maiores consequências para a saúde mental é a depressão e a ansiedade generalizada. Somado a isso, pode-se pontuar o estresse crônico, a exaustão e o esgotamento que defrontam pela extensa carga de trabalho. Tais profissionais estão expostos, todos os dias, a sentimento de impotência e angústia, pois não há meios suficientes para combater a situação (TEIXEIRA et al., 2020).

Diante disso, a sobrecarga, o estresse contínuo e a alta responsabilidade do cargo podem gerar doenças ocupacionais que acometerão tais trabalhadores, tendo a Síndrome de Burnout como exemplo (SANTANA; SANTOS; SANTOS, 2020). Sendo assim, deve-se buscar maneiras de prevenção quanto a síndrome e, também tratar profissionais acometidos. É preciso cuidar de quem cuida.

\section{METODOLOGIA}

\subsection{DELINEAMENTO DO ESTUDO}

Pesquisa de campo, descritiva exploratória com abordagem quantitativa seguida de uma intervenção. 


\subsection{LOCAL DA PESQUISA}

Unidade de Saúde da Família Itamarati.

\subsection{PARTICIPANTES, CRITÉRIO DE INCLUSÃO/ OU TIPO DE DADOS A SEREM COLETADOS}

Critério de inclusão: Para a coleta de dados os participantes do estudo serão todos os profissionais de saúde de ambos sexos e acima de 18 anos da USF.

Critério de exclusão: Profissionais que estiverem de férias, atestado ou licença para tratamento de estado de saúde.

Participarão do projeto aproximadamente 35 pessoas.

\subsection{INSTRUMENTOS UTILIZADOS}

Para rastrear a doença será utilizado o INVENTÁRIO DE BURNOUT DE MASLACH (Maslach Burnout Inventory - Human Services Survey [MBI-HSS]). O MBI-HSS é uma escala autoaplicada que apresenta frases afirmativas sobre os sentimentos e atitudes dos profissionais em relação ao seu trabalho. Possui 22 itens que avaliam as três dimensões da Síndrome de Burnout: exaustão emocional, relacionada à sensação de esgotamento físico e mental e ao sentimento de falta de energia e entusiasmo; despersonalização, com enfoque nas alterações na atitude do trabalhador, como distanciamento e impessoalidade em relação aos clientes ou usuários de seu serviço; e realização profissional, cujos itens são analisados de forma inversa, sendo possível verificar o sentimento de insuficiência, baixa autoestima, fracasso profissional e desmotivação com o trabalho

Além disso, será utilizado 1 termo: termo de consentimento livre esclarecido. 0 qual convida o profissional para a pesquisa.

\subsection{COLETA DE DADOS}

A coleta de dados será iniciada após a autorização do Comitê de Ética e Pesquisa (CEP) do Centro Universitário de Patos de Minas - UNIPAM (ANEXO A) e a Folha de Rosto (esta será gerada na Plataforma Brasil após o cadastro da pesquisa).

\subsection{ANÁLISE DOS DADOS}

A análise dos dados do questionário, será feita através dos seguintes pontos de corte: exaustão emocional (baixo: zero a 15; médio: 16 a 25; e alto: 26 a 54), despersonalização (baixo: zero a 2; médio: 
3 a 8; e alto: 9 a 30) e realização profissional (baixo: zero a 33; médio: 34 a 42; e alto: 43 a 48) (PEREIRA, 2010). A SB foi constada nos profissionais nos quais houve a combinação de alta exaustão emocional, alta despersonalização e baixa realização profissional. (VASCONCELOS; DE MARTINO, 2017)

\subsection{ASPÉCTOS ÉTICOS}

Este projeto será submetido ao Comitê de Ética em Pesquisa do Centro Universitário de Patos de Minas - CEP - UNIPAM (ANEXO A), via Plataforma Brasil. O mesmo obedecer às normas e legislação nacional vigente, para realização da pesquisa envolvendo seres humanos, conforme a Resolução do Conselho Nacional de Saúde 466/2012.

A pesquisadora solicitará permissão aos participantes através do Termo de Consentimento Livre e Esclarecimento (APÊNDICE A), para proceder ao preenchimento do questionário após a explicação e esclarecimento sobre os objetivos da pesquisa, certificando-o sobre o sigilo que será mantido em relação a sua pessoa.

Será respeitada a privacidade, sigilo e a liberdade de recusar-se a participar da pesquisa, conforme a Resolução do Conselho Nacional de Saúde no 466 de 12/12/2012.

Caso ocorra percepção, por parte dos pesquisadores, de algum sinal de desconforto, ansiedade ou constrangimento da criança ou dos responsáveis, a mesma terá sua abordagem imediatamente encerrada.

\subsubsection{TERMO DE CONSENTIMENTO LIVRE ESCLARECIDO}

Posteriormente ao convite para a participação na pesquisa, os profissionais de saúde da USF serão convidados a assinar o Termo de Consentimento Livre e Esclarecimento (APÊNDICE B), de acordo com as diretrizes da Resolução 466/2012 do Conselho Nacional de Saúde (CNS), do Ministério da Saúde do Brasil. Serão explicados os objetivos do estudo, procedimentos, utilizando-se de linguagem clara, visando assim salvaguardar os direitos dos sujeitos envolvidos.

Após a leitura e assinatura dos Termos citados acima, os sujeitos da pesquisa receberão orientações acerca da prevenção da Síndrome de Burnout. Os questionários serão guardados em um envelope sob responsabilidade dos pesquisadores. 


\subsubsection{CRITÉRIOS PARA SUSPENDER OU ENCERRAR A PESQUISA}

A pesquisa será dada por encerrada caso o paciente não concordar em participar ou não assinar o Termo de Consentimento Livre e Esclarecido. O paciente pode desistir de sua participação em qualquer fase da realização deste trabalho, sem qualquer tipo de prejuízo à sua assistência. 0 pesquisador tem o dever de interromper a pesquisa, caso esta acarrete qualquer tipo de dano ao paciente.

\subsubsection{ANÁLISE CRÍTICA DE RISCOS E BENEFÍCIOS}

O estudo não oferece danos físicos à saúde dos pacientes pesquisados, e nem a sua integridade moral, este se propõe a realização de questionários e práticas integrativas que não caracterizam intervenções invasivas. Porém tem-se o risco inerente a qualquer trabalho, como a identificação dos pacientes e para evitar isso, os dados coletados não serão em nenhum momento associada especificamente a instituição pesquisada. Sendo assim a identidade dos pacientes preservada, não sendo em nenhum momento o nome dos mesmos mencionados nos resultados da pesquisa, nem sendo identificados nominalmente. Serão identificados por números absolutos.

Como benefícios os profissionais de Saúde da USF poderão ter o conhecimento de como prevenir a síndrome de Burnout e como amenizar os danos causadas por ela.

\subsubsection{UTILIZAÇÃO DOS RESULTADOS}

Os resultados encontrados na forma de dados terão a sua confiabilidade garantida para uso, única e exclusivamente, para alcançar os objetivos propostos da pesquisa. Essas informações serão utilizadas para construção de artigo e resumos direcionados para publicação em revista especializada e publicações em eventos (V Mostra Cientifica do INESC do Curso de Medicina do Centro Universitário de Patos de Minas - UNIPAM) e requisito para conclusão de curso de medicina.

\subsubsection{RESPONSABILIDADES DO PESQUISADOR}

O pesquisador tem a responsabilidade de manter o sigilo quanto às informações coletadas, publicar os dados sem constranger os profissionais e promover sua colaboração para o crescimento da pesquisa científica no âmbito do Centro Universitário de Patos de Minas e na Estratégia de Saúde da Família. Segue em anexo o Termo de Compromisso da Equipe Executora (ANEXO C). 


\subsection{RECURSOS NECESSÁRIOS PARA PESQUISA}

Para a realização desta pesquisa não serão necessários recursos financeiros da instituição proponente Centro Universitário de Patos de Minas-MG - UNIPAM e nem da instituição coparticipante USF Itamarati. Os recursos materiais, como impressão dos termos e do questionário, serão de responsabilidade e financiamento da própria equipe de pesquisadores.

\section{RESULTADOS E DISCUSSÃO}

Dessa pesquisa, participaram 25 profissionais da unidade de saúde da família. Dentre eles, 22 (88\%) pertenciam ao sexo feminino e 3 (12\%) ao sexo masculino, 15 (60\%) eram casados; 4 (16\%) eram solteiros; 3 (12\%) divorciados; 2 (8\%) viúvos e 1 (4\%) em união estável. Em relação à profissão, participaram da pesquisa 11 (44\%) Agentes comunitários de Saúde (ACS); 2 (8\%) Médicos de Família e Comunidade (MFC); 1 (4\%) Auxiliar de serviços gerais (ASG); 2 (8\%) enfermeiros; 2 (8\%) Auxiliares de enfermagem; 3 (12\%) Agentes de endemias; 1 (4\%) Fisioterapeuta e 3 (12\%) estagiários.

A partir da análise da Tabela 1, observa-se que a maioria da amostra foi composta por profissionais do sexo feminino, casadas e a maioria atua como Agente Comunitário de Saúde.

Tabela 1 - Características sócio demográficas dos profissionais de saúde.

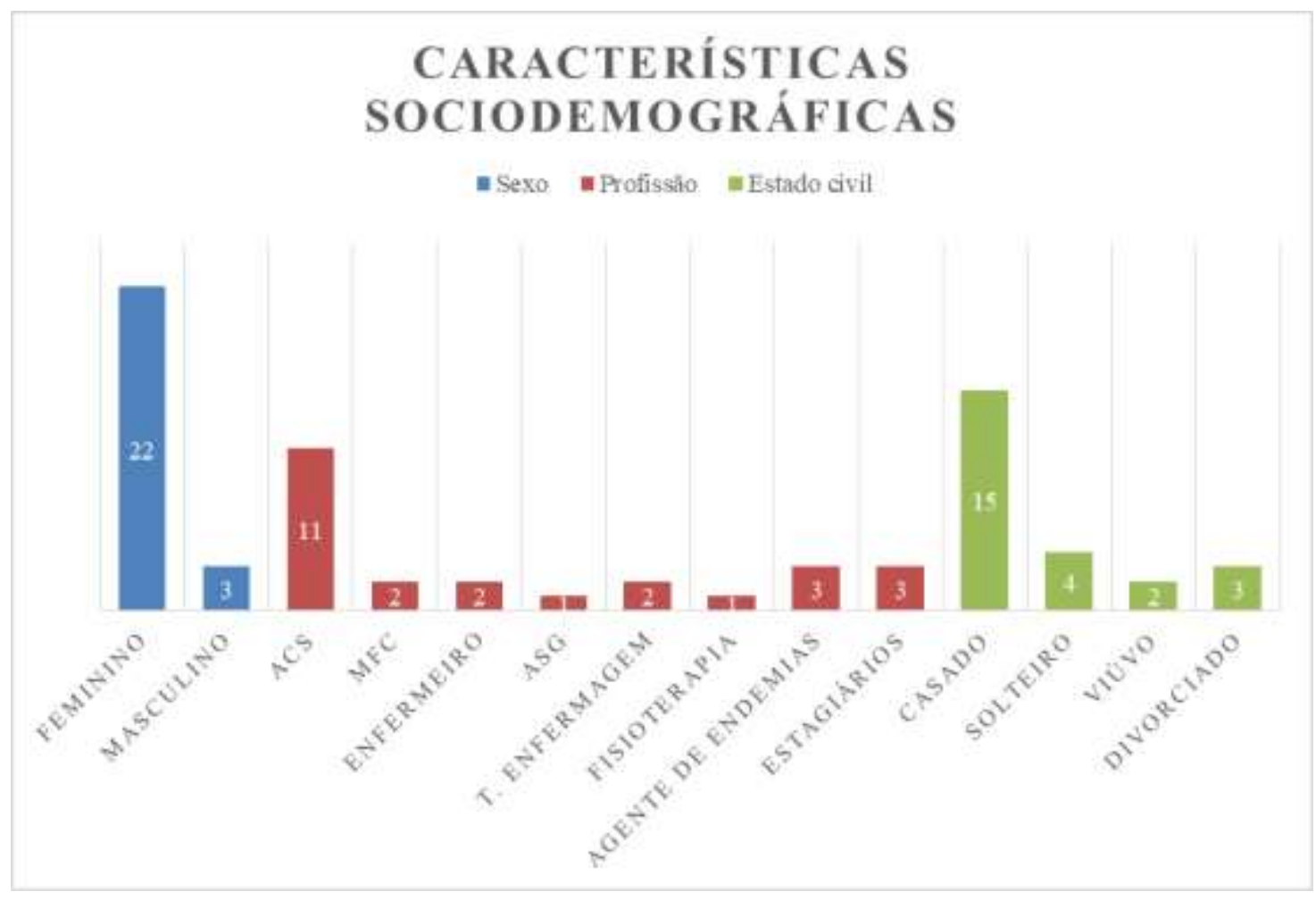

Fonte: Questionário MBI-HSS 
Após a aplicação do questionário, obtemos os dados relacionados as três dimensões da SB. $\mathrm{Na}$ dimensão "Exaustão emocional", 11 (44\%) profissionais encaixaram-se no nível alto, 6 (24\%) no moderado e 8 (32\%) no baixo. Já na dimensão "Realização profissional", cujos dados são analisados de maneira inversa, 8 (32\%\%) profissionais encaixaram-se no nível alto, 13 (52\%) no moderado e 4 (16\%) no baixo. E por fim, na dimensão "Despersonalização", 10 (40\%) profissionais encaixaram-se no nível alto, 1 (4\%) no moderado e 14 (56\%) no baixo. Com isso podemos afirmar que possuem grande chance de terem SB 2 (8\%) profissionais da unidade de saúde.

Tabela 2 - Distribuição dos profissionais de Saúde nas dimensões analisadas do MBI-HSS

\begin{tabular}{|c|c|c|}
\hline Dimensão & Nível & $\mathbf{N}(\%)$ \\
\hline \multirow[t]{3}{*}{ Exaustão Emocional } & Alto & $11(44)$ \\
\hline & Moderado & $6(24)$ \\
\hline & Baixo & $8(32)$ \\
\hline \multirow[t]{3}{*}{ Realização Profissional } & Alto & $8(32)$ \\
\hline & Moderado & $13(52)$ \\
\hline & Baixo & $4(16)$ \\
\hline \multirow[t]{3}{*}{ Despersonalização } & Alto & $10(40)$ \\
\hline & Moderado & $1(4)$ \\
\hline & Baixo & $14(56)$ \\
\hline \multirow[t]{2}{*}{ Prevalência da SB } & Presente & $2(8)$ \\
\hline & Ausente & $23(92)$ \\
\hline
\end{tabular}

Fonte: Questionário MBI-HSS

A partir da análise dos questionários respondidos, da Tabela 2 e de acordo com os pontos de corte propostos por Vasconcelos 2017, observa-se a SB em 2 (8\%) profissionais de Saúde da unidade de Saúde durante a pandemia. Quando os componentes da SB são analisados de forma isolada, destacase a dimensão "Exaustão Emocional", onde a maioria dos profissionais de saúde (44\%) identificam a sobrecarga do trabalho como fator gerador de estresse, além disso o estudo de Tamayo e Trócoli 2009 verificou que essa dimensão é o fator mais consistente para SB. Analisando as possíveis causas da sobrecarga laboral, o estudo de Guimarães 2017, demonstra que a população possui um olhar curativista, em relação as unidades de atenção primárias, as quais se baseiam na promoção e prevenção de Saúde. Essa questão é exemplificada pela demanda espontânea presente no cotidiano do local. Por fim, nas demais dimensões (Realização profissional e Despersonalização) a maioria dos profissionais analisados não apresentaram pontuação que demonstrem alto risco para o desenvolvimento da SB. 


\section{CONCLUSÃO}

Conclui-se através da pesquisa que, na unidade analisada, a SB é pouco prevalente. Apesar disso, destaca-se o alto índice de exaustão emocional nos profissionais, o que pode ter sido agravado pela pandemia. Diante desses fatores, propusemos algumas atividades na UBS como: atendimento psicológico, auriculoterapia e consulta médica, visando atuar na prevenção e promoção de saúde, bem como atenuar o fator precipitante mais prevalente. Com a melhora da pandemia, acredita-se que a exaustão emocional, realização profissional e despersonalização tenham uma melhora epidemiológica, pois haverá redução nas consultas de demanda espontânea relacionadas. 


\section{REFERÊNCIAS}

BARRETO, Clara. Prevalência de Burnout é maior em médicos que atuam na linha de frente da Covid19. PEBMED, set., 2020. Disponível em: https://pebmed.com.br/prevalencia-de-burnout-e-maior-emmedicos-que-atuam-na-linha-de-frente-da-covid-19/ .

BRASIL. Medida Provisória n. 927, de 22 de março de 2020. Dispõe sobre as medidas trabalhistas para enfrentamento do estado de calamidade pública reconhecido pelo Decreto Legislativo n. 6, de 20 de março de 2020, e da emergência de saúde pública de importância internacional decorrente do coronavírus (covid-19), e dá outras providências. Diário Oficial da União: seção 1, Brasília, DF, ano 158, n. 55-L, p. 1-3, 22 mar. 2020. Edição extra.

CÂNDIDO, Jéssica; SOUZA, Lindalva Rocha de. Síndrome de Bornout: as novas formas de trabalho que adoecem. Psicologia.pt, 28 jan. 2017. Disponível em:

https://www.psicologia.pt/artigos/textos/A1054.pdf .

COMO ANDA A SAÚDE DOS PROFISSIONAIS DA ENFERMAGEM? Caderno de Graduação - Ciências Biológicas e da Saúde - UNIT - SERGIPE, v. 6, n. 2, p. 101-112, 7 set. 2020.

COVID-19: protecting health-care workers. Lancet, [publicação online], v. 395, n. 10228, p.922, 21 mar. 2020. DOI: https://doi.org/10.1016/S0140-6736(20)30644-9

CRACCO, Claudia Lucimara Andrade Calvacante; SALVADOR, Juliana dos Anjos. IDENTIFICAÇÃO DA SÍNDROME DE BURNOUT NA EQUIPE DE ENFERMAGEM DE UMA UNIDADE DE PRONTO ATENDIMENTO. 2010. 60f. Monografia (Trabalho de conclusão de curso de enfermagem) Unisalesiano, Lins - SP, 2010

HUMEREZ, Dorisdaia Carvalho de; OHL, Rosali Isabel Barduchi; SILVA, Manoel Carlos Neri da. SAÚDE MENTAL DOS PROFISSIONAIS DE ENFERMAGEM DO BRASIL NO CONTEXTO DA PANDEMIA COVID-19: AÇÃO DO CONSELHO FEDERAL DE ENFERMAGEM. Cogitare enfermagem, [internet ou s.l.] v. 25, n. 0, 2020. DOI: http://dx.doi.org/10.5380/ce.v25i0.74115

MEIRA, Karina Cardoso et al. O perfil e a sobrecarga na jornada de trabalho de profissionais da linha de frente ao combate à pandemia da Covid-19. Programa de Pós-Graduação em Demografia - Centro de Ciências Exatas e da Terra - UFRN, Natal, RN, 13 maio 2020. Disponível em: https://demografiaufrn.net/2020/05/13/sobrecarga-linha-frente/ . Acesso em: (Texto de Divulgação Científica).

PÊGO, Francinara Pereira Lopes e; PÊGO, Delcir Rodrigues. Síndrome de Burnout. Revista Brasileira de Medicina do Trabalho, [s.I.], v. 14, n. 2, p. 171-176, 2016. DOI: http://dx.doi.org/10.5327/z1679443520162215

REZENDE, Roseli; BORGES, Najla Moreira Amaral; FROTA, Oleci Pereira. Síndrome de Burnout e absenteísmo em enfermeiros no contexto hospitalar: revisão integrativa da literatura brasileira. Comunicação em Ciências da Saúde, [s.I.], v. 23, n. 3, p. 243-252, jul./set., 2012. Disponível em: http://bvsms.saude.gov.br/bvs/periodicos/revista_ESCS_v23_n3_a6_sindrome_burnout_absenteism o.pdf . Acesso em:

SANTANA, Ana Clara Cruz Santos de; SANTOS, Layane Estefany Siqueira dos; SANTOS, Lucas Siqueira dos. COVID-19, ESTRESSE CONTÍNUO E SÍNDROME DE BURNOUT: 
SOUSA JÚNIOR, Belarmino Santos de et al. Pandemia do coronavírus: estratégias amenizadoras do estresse ocupacional em trabalhadores da saúde. Enfermagem em foco, [Brasília], v. 11, n. 1, p. 148154, ago. 2020. Disponível em:

http://biblioteca.cofen.gov.br/wp-content/uploads/2020/09/pandemia-coronavirus-estresseocupacional-trabalhadores-saude.pdf .

SOUZA, Ágnes Karolyne da Silva Souza; MARIA, Anderson Leandro. SíNDROME DE BURNOUT EM DIFERENTES ÁREAS PROFISSIONAIS E SEUS EFEITOS. Revista Acta Brasileira do Movimento Humano, Paraná, v. 6, n. 3, p. 1-12, jul./set. 2016. Disponível em:

http://www.periodicos.ulbra.br/index.php/actabrasileira/article/view/2920/2492 .

TEIXEIRA, Fernanda Gomes; SILVA, Mara Regina Santos da; MEDEIROS, Gabriela Luvielmo. Síndrome de Burnout - a interface entre o trabalho na área da educação e na enfermagem. Rev. Enf. Ref., Coimbra, v. serllI, n. 2, p. 101-109, dez. 2010. Disponível

em:http://www.scielo.mec.pt/scielo.php?script=sci_arttext\&pid=S087402832010000400011\&lng=pt \&nrm=iso .

TEIXERA, Carmen Fontes de Souza et al. A saúde dos profissionais de saúde no enfrentamento da pandemia de Covid-19. Ciência e saúde coletiva, Rio de Janeiro, v. 25, n. 9, p. 3465-3474, Set., 2020. DOI: https://doi.org/10.1590/1413-81232020259.19562020

TRIGO, Telma Ramos; TENG, Chei Tung; HALLAK, Jaime Eduardo Cecilio. Síndrome de Burnout ou estafa profissional e os transtornos psiquiátricos. Rev. Psiquiatr. Clin., São Paulo, v. 34, n. 5, p. 222233, 2007. DOI: https://doi.org/10.1590/S0101-60832007000500004

VELOZ, Andrés Fernando Vinueza et al. Síndrome de Burnout en médicos/as y enfermeros/as ecuatorianos durante la pandemia de COVID-19. Scielo [org.], jun., 2020 DOI: https://doi.org/10.1590/SciELOPreprints.708

WORLD HEALTH ORGANIZATION. Statement on the second meeting of the International Health Regulations (2005) Emergency Committee regarding the outbreak of novel coronavirus (2019-nCoV). [publicação online], jan., 2020a. Disponível em: https://www.who.int/news/item/30-01-2020statement-on-the-second-meeting-of-the-international-health-regulations-(2005)-emergencycommittee-regarding-the-outbreak-of-novel-coronavirus-(2019-ncov) .

WORLD HEALTH ORGANIZATION. WHO Director-General's opening remarks at the media briefing on COVID-19-11 March 2020. [publicação online], mar, 2020b. Disponível em: https://www.who.int/director-general/speeches/detail/who-director-general-s-opening-remarks-atthe-media-briefing-on-covid-19---11-march-2020

ZHU, Na et al. A Novel Coronavirus from Patients with Pneumonia in China, 2019. N England J of Medicine, [publicação online], v. 382, n. 8, p. 727-733, 2020. DOI: 10.1056/NEJMoa2001017

TAMAYO, Mauricio Robayo; TRÓCCOLI, Bartholomeu Tôrres. Construção e validação fatorial da Escala de Caracterização do Burnout (ECB). Estudos de Psicologia (Natal), v. 14, n. 3, p. 213-221, 2009. 
ANEXOS

ANEXO A - CARTA DE ENCAMINHAMENTO AO COMITÊ DE ÉTICA

Encaminho a V. S. a para apreciação do CEP/UNIPAM o projeto de pesquisa: "SÍNDROME DE BURNOUT DURANTE E PÓS-PANDEMIA DA COVID-19 EM PROFISSIONAIS DA UNIDADE DE SAUUDE DA FAMÍLIA E ESTRATÉGIAS DE PROMOÇÃO DE SAÚDE”

NOME DO(A) ORIENTADOR(A): Rúbia Carla Oliveira

CPF: $08245772640 \quad$ RG: MG 14967206 TELEFONE: (34) 99149-0006

Endereço: Rua Jaime Ramos, 92, Caiçaras

Currículo lattes: http://lattes.cnpq.br/9783707622953255

Assinatura do(a) Orientador(a):

Nome(s) do(a)(s) aluno(a)(s) pesquisador: Isabella Camin Pena

CPF: 13364602611 RG: MG 16.934.66 TELEFONE: (34) 9 9228-3643

Endereço: Rua Diacuí, 226, apto 501, Caiçaras.

Currículo lattes: http://lattes.cnpq.br/8879982078968148

Nome(s) do(a)(s) aluno(a)(s) pesquisador: Leilany Marins Andrino

CPF: $10933767676 \quad$ RG: MG 18879530 TELEFONE: (34) 988418046

Endereço: Rua Tonho do nico, 56 apto 203

Currículo lattes: http://lattes.cnpq.br/6590520611974243

Nome(s) do(a)(s) aluno(a)(s) pesquisador: Izabella Araujo de Oliveira

CPF:0327931558

RG: DF 3118732 TELEFONE: (61) 996758486 
Endereço: Rua Nito de Deus Viera, 175, apto 102, Caiçaras

Currículo lattes: http://lattes.cnpq.br/2755217442602618

Nome(s) do(a)(s) aluno(a)(s) pesquisador: Dyego Douglas Dias Silva

CPF: $07540572671 \quad$ RG: MG $14747582 \quad$ TELEFONE: (34) 988634627

Endereço: Rua Antônio Tomás de Magalhães, $n^{\circ} 283$, apt ${ }^{\circ} .: 101$

Currículo lattes: http://lattes.cnpq.br/5160475022409661

Nome(s) do(a)(s) aluno(a)(s) pesquisador: Vítor Augusto Ferreira Braga

CPF: $11529871603 \quad$ RG: MG 20189083 TELEFONE: (34) 9 9969-4600

Endereço: Rua Sebastião Tomaz de Magalhães, $n^{\circ} 722$, Nova Floresta

Currículo lattes: http://lattes.cnpq.br/0085218132732428

Nome(s) do(a)(s) aluno(a)(s) pesquisador: Rafael Freitas Silva Peralta

CPF:02226457682 RG: MG 16225229 TELEFONE: (34) 999940220

Endereço: Rua dos benvindos 244, apto 203 Bairro Caiçaras

Currículo lattes: http://lattes.cnpq.br/1637583493852745

Assinatura do(a)(s) aluno(a)(s) pesquisador(es)

Para projetos de dissertação de mestrado e tese de doutorado, informar data da qualifícação: 


\section{ANEXO B - DECLARAÇÃO DA INSTITUIÇÃO CO-PARTICIPANTE}

\section{DECLARAÇÃO DA INSTITUIÇÃO CO-PARTICIPANTE}

Declaro estar ciente que o Projeto de Pesquisa "SÍNDROME DE BURNOUT DURANTE E PÓS-PANDEMIA DA COVID-19 EM PROFISSIONAIS DA UNIDADE DE SAÚDE DA FAMÍLIA E ESTRATÉGIAS DE PROMOÇÃO DE SAÚDE” será avaliado por um Comitê de Ética em Pesquisa e concordar com o parecer ético emitido por este CEP, conhecer e cumprir as Resoluções Éticas Brasileiras, em especial a Resolução CNS 466/12. Esta Instituição está ciente de suas co-responsabilidades como instituição co-participante do presente projeto de pesquisa, e de seu compromisso no resguardo da segurança e bem-estar dos sujeitos de pesquisa nela recrutados, dispondo de infraestrutura necessária para a garantia de tal segurança e bemestar.

Autorizo os pesquisadores Dyego Douglas Dias Silva, Isabella Camin Pena, Izabella Araújo de Oliveira, Leilany Marins Andrino, Rafael Freitas Peralta, Vítor Augusto Ferreira Braga, Rúbia Carla Oliveira e Marilene Rivany Nunes realizarem as etapas aplicação de questionários e desenvolvimento de atividades práticas e teóricas educativas utilizando-se da infraestrutura desta Instituição.

Carlos Antônio Silva Rezende

Secretário de Saúde

Patos de Minas, de 20 
ANEXO C - TERMO DE COMPROMISSO DA EQUIPE EXECUTORA

\section{Termo de Compromisso da Equipe Executora}

Nós, abaixo assinados, nos comprometemos a desenvolver o projeto de pesquisa "SÍNDROME DE BURNOUT DURANTE E PÓS-PANDEMIA DA COVID-19 EM PROFISSIONAIS DA UNIDADE DE SAÚDE DA FAMÍLIA E ESTRATÉGIAS DE PROMOÇÃO DE SAÚDE”, de acordo com a Resolução 466/12/CNS.

\section{Rúbia Carla Oliveira}

rubiacoliveira@unipam.edu.br

Telefone: (35) 998192060

Nome do Pesquisador Principal 1 (orientador)

\section{Marilene Rivany Nunes}

maryrivany@yahoo.com.br

Telefone: (34) 9 9103-8038

Nome do Pesquisador Principal 2(orientador)

Rafael Freitas Silva Peralta peraltarfs@gmail.com

Telefone: (34) 999940220

Nome do Pesquisador 1 (Orientando)

Dyego Douglas Dias Silva

dyegodds@hotmail.com

Telefone: (34) 988634627

Nome do Pesquisador 2 (Orientando) 


\begin{tabular}{c} 
Isabella Camin Pena \\
isabella.camin@yahoo.com.br \\
Telefone: (34) 99228-3643 \\
Nome do Pesquisador 3 (orientando) \\
\\
Izabella Araújo De Oliveira \\
araujoo.izabella@gmail.com \\
Telefone: (61) 99675-8486 \\
Nome do Pesquisador 4 (Orientando) \\
\\
Leilany Marins Andrino \\
leilany.andrino@gmail.com \\
Telefone: 988418046 \\
Nome do Pesquisador 5 (Orientando) \\
\hline Nome do Pesquisador 6 (Orientando) \\
vitoraugustofb@gmail.com \\
\hline
\end{tabular}




\section{APÊNDICE A - INSTRUMENTO MASLACH BURNOUT INVENTORY (MBI)}

Profissão:

Sexo: ( ) Masculino ( ) Feminino Data de nascimento:

Estado civil:

Por favor, leia atentamente cada um dos itens a seguir e responda se já experimentou o que é relatado, em relação a seu trabalho. Caso nunca tenha tido tal sentimento, responda " 0 " (zero) na coluna ao lado. Em caso afirmativo, indique a frequência (de 1 a 6) que descreveria melhor seus sentimentos, conforme a descrição abaixo:

0 . Nunca

2. Uma vez ao mês ou menos

4. Uma vez por semana

6. Todos os dias
1. Uma vez ao ano ou menos

3. Algumas vezes ao mês

5. Algumas vezes por semana

\begin{tabular}{|c|c|}
\hline 1. & Sinto-me esgotado/a ao final de um dia de trabalho \\
\hline 2. & Sinto-me como se estivesse no meu limite \\
\hline 3. & $\begin{array}{r}\text { Sinto-me emocionalmente exausto/a com o meu } \\
\text { trabalho }\end{array}$ \\
\hline 4. & Sinto-me frustrado/a com o meu trabalho \\
\hline 5. & Sinto-me esgotado/a com o meu trabalho \\
\hline 6. & Sinto que estou trabalhando demais nesse emprego \\
\hline 7. & $\begin{array}{r}\text { Trabalhar diariamente com pessoas me deixa muito } \\
\text { estressado/a }\end{array}$ \\
\hline 8. & $\begin{array}{r}\text { Trabalhar com pessoas o dia todo me exige um } \\
\text { grande esforço }\end{array}$ \\
\hline 9. & $\begin{array}{r}\text { Sinto-me cansado/a quando levanto de manhã e } \\
\text { tenho que encarar outro dia de trabalho }\end{array}$ \\
\hline 10. & Sinto-me cheio/a de energia \\
\hline 11. & $\begin{array}{r}\text { Sinto-me estimulado/a de trabalhar em contato com } \\
\text { os pacientes }\end{array}$ \\
\hline 12. & $\begin{array}{r}\text { Sinto-me que posso criar um ambiente tranquilo } \\
\text { para os pacientes }\end{array}$ \\
\hline 13. & $\begin{array}{r}\text { Sinto que influencio positivamente a vida dos } \\
\text { outros através do meu trabalho }\end{array}$ \\
\hline 14. & $\begin{array}{r}\text { Lido de forma adequada com os problemas dos } \\
\text { pacientes }\end{array}$ \\
\hline 15. & $\begin{array}{r}\text { Posso entender com facilidade o que sentem os } \\
\text { pacientes }\end{array}$ \\
\hline 16. & $\begin{array}{l}\text { Sinto que sei tratar de forma tranquila os problemas } \\
\text { emocionais do meu trabalho }\end{array}$ \\
\hline 17. & $\begin{array}{r}\text { Tenho que conseguir muitas realizações em minha } \\
\text { profissão }\end{array}$ \\
\hline
\end{tabular}




\begin{tabular}{|c|c|}
\hline 18. & $\begin{array}{r}\text { Sinto que os pacientes culpam-me por alguns dos } \\
\text { seus problemas }\end{array}$ \\
\hline 19. & $\begin{array}{r}\text { Sinto que trato alguns pacientes como se fossem } \\
\text { objetos }\end{array}$ \\
\hline 20. & $\begin{array}{r}\text { Tenho me tomado mais insensível com as pessoas } \\
\text { desde que exerço esse trabalho }\end{array}$ \\
\hline 21. & $\begin{array}{r}\text { Não me preocupo realmente com o que ocorre com } \\
\text { alguns dos meus pacientes }\end{array}$ \\
\hline 22. & $\begin{array}{r}\text { Preocupo-me o fato de que este trabalho esteja me } \\
\text { endurecendo emocionalmente }\end{array}$ \\
\hline
\end{tabular}




\section{APÊNDICE B - TERMO DE CONSENTIMENTO LIVRE E ESCLARECIDO PARA ADULTOS}

\section{Termo de Consentimento Livre e Esclarecido - TCLE}

Titulo da pesquisa: Síndrome de burnout durante e pós-pandemia da covid-19 em profissionais da unidade de saúde da família e estratégias de promoçào de saúde

Instituiçâo do (a) ou dos (as) pesquisadores (as): Centro Universitário de Patos de Minas UNIPAM

Membros da equipe de pesquisa: Dyego Douglas Dias Silva, Isabella Camin Pena, Izabella Araújo de Oliveira, Leilany Marins Andrino, Rafael Freitas Peralta, Vitor Augusto Ferreira Braga, Rúbia Carla Oliveira, Marilene Rivany Nunes

Vocé está sendo convidado(a) a participar do projeto de pesquisa acima citado. O texto abaixo apresenta todas as informações necessárias sobre o que estamos fazendo. Sua colaboração neste estudo será de muita importância para nós, mas se desistir a qualquer momento, isso não the causará prejuizo.

O nome deste documento que você está lendo é Termo de Consentimento Livre e Esclarecido (TCLE).

Antes de decidir se deseja participar (de livre e espontânea vontade) você deverả ler e compreender todo o conteudo deste texto. Ao final. caso decida participar, você será solicitado a assiná-lo e receberá uma cópia do mesmo.

Antes de assinar, faça perguntas sobre tudo que não tiver fic ado bem compreendido. A equipe deste estudo responderá às suas perguntas a qualquer momento (antes, durante e após o estudo).

\section{Natureza e objetivos do estudo}

- O objetivo deste estudo é identificar a presença de Síndrome de Bumout (SB) nos profissionais da Unidade de Saúde da Familia, além de caracterizar o perfil demográfico, social e clinico dos trabalhadores e implantar estratégias de prevenção para tal sindrome na unidade.

- Vocé está sendo convidado a participar respondendo o Instrumento Maslach Burnout Inventory, nos ajudando a analisar a prevalència da SB na unidade e desenvolver práticas adequadas a demanda.

\section{Procedimentos do estudo}

- Sua participação consiste em responder um questionário com 22 perguntas, a respeito da exaustão emocional, realização profissional e despersonalização.

- O/os procedimento (s) é responder as questões objetivas do questionário.

- Não haverả nenhuma outra forma de envolvimento ou comprometimento neste estudo.

- A pesquisa será realizada na Unidade de Saúde da Familia Itamarati.

\section{Riscos e beneficios}

- Este estudo possui riscos mínimos, apenas a identificação dos participantes através dos questionários.

- Medidas preventivas serào tomadas pelo acesso restrito aos pesquisadores das 
informações coletadas durante o estudo para minimizar qualquer risco ou incômodo.

- Caso esse procedimento possa gerar algum tipo de constrangimento, você não precisa realizá-lo.

- Com sua participação nesta pesquisa você terá menor risco de apresentar $\mathrm{SB}$, diante das informações compartilhadas, além de contribuir para maior conhecimento sobre.

\section{Participação, recusa e direito de se retirar do estudo}

- Sua participação é voluntária. Você não terá nenhum prejuízo se não quiser participar.

- Você poderá se retirar desta pesquisa a qualquer momento, basta entrar em contato com um dos pesquisadores responsáveis.

- Conforme previsto pelas normas brasileiras de pesquisa com a participação de seres humanos, você não receberá nenhum tipo de compensação financeira pela sua participação neste estudo.

\section{Ressarcimento e Indenização:}

- O trabalho não trará custos aos participantes e será aplicado no horário de aula, não interferindo em sua rotina. Você terá a garantia ao direito à indenização diante de eventuais danos decorrentes da pesquisa.

\section{Confidencialidade}

- Seus dados serão manuseados somente pelos pesquisadores e não será permitido o acesso a esses dados por outras pessoas.

- Os dados e instrumentos utilizados questionário ficarão guardados sob a responsabilidade de Grupo G12, do $6^{\circ}$ semestre de medicina do UNIPAM, com a garantia de manutenção do sigilo e confidencialidade, e arquivados por um período de 5 anos; após esse tempo, esses arquivos serão destruídos.

- Os resultados deste trabalho poderão ser apresentados em encontros ou revistas científicas. Entretanto, eles mostrarão apenas os resultados obtidos como um todo, sem revelar seu nome, instituição a qual pertence ou qualquer informação que esteja relacionada com sua privacidade.

Se houver alguma consideração ou dúvida referente aos aspectos éticos da pesquisa, entre em contato com o Comitê de Ética em Pesquisa do Centro Universitário de Patos de Minas CEP/UNIPAM, que aprovou esta pesquisa, pelo telefone (34)3823-0348 ou pelo e-mail cep@unipam.edu.br.Também entre em contato para informar ocorrências irregulares ou danosas durante a sua participação no estudo.

$\mathrm{Eu}$, $\mathrm{RG}$ após receber explicação completa dos objetivos e dos procedimentos envolvidos nesta pesquisa, concordo voluntariamente em fazer parte deste estudo.

Este Termo de Consentimento encontra-se impresso em duas vias, sendo que uma cópia será arquivada pelo pesquisador responsável, e a outra será fornecida ao senhor (a). 
Patos de Minas, de

\section{Participante}

Rafael Freitas Silva Peralta, celular (34) 999940220/ e-mail: peraltarfs@gmail.com 


\section{Capítulo 2}

do:

PREVALÊNCIA DAS DOENÇAS CRÔNICAS NÃO TRANSMISSÍVEIS NA ÁREA DE ABRANGÊNCIA DA UAPS NOVA FLORESTA: UM ENFOQUE NO DIABETES E HIPERTENSÃO 
Resumo: O projeto de saúde no território (pst) consiste em uma estratégia de orientação e organização do trabalho de equipes de saúde por meio da discussão das necessidades de saúde no território (silva, 2016). É importante para identificação de doenças prevalentes na população brasileira como hipertensão arterial sistêmica (has) e diabetes mellitus. A hipertensão arterial sistêmica é a mais frequente das doenças crônicas não transmissíveis (dcnt) e a prevalência do diabetes vem crescendo mundialmente, configurando-se atualmente como uma epidemia. A pesquisa objetivou caracterizar o perfil da comunidade e identificar a prevalência dessas duas dent na população estudada. Foi realizado um estudo descritivo, por meio de levantamento de dados, desenvolvido na unidade de atenção primária à saúde josé claudio arpini, no município de patos de minas- mg, no ano de 2017. Coleta feita por meio de dados do controle de diabéticos e hipertensos das 7 microáreas (ma) atendidas pela equipe lua através dos cadernos de campo das agentes comunitárias de saúde (acs) de cada ma. Os dados foram analisados e distribuídos em tabelas e gráficos comparativos com a situação nacional. Evidenciou-se que o índice de pessoas, por microárea, acometidas por hipertensão arterial e diabetes é, em geral, menor do que a média nacional, com exceção da ma 3, em que os índices foram superiores aos nacionais em ambos os acometimentos. Destaca-se a importância do pst na atenção primária para o desenvolvimento de ações de promoção de saúde e controle dos fatores de risco associados às dent mais prevalentes na população.

Palavras-chave: Atenção primária. Diabetes mellitus. Hipertensão. Medicina de família e comunidade. 


\section{INTRODUÇÃO}

A hipertensão arterial (ha) é uma condição clínica multifatorial caracterizada por elevação sustentada dos níveis pressóricos $\geq 140$ e/ou 90 mmhg que frequentemente se associa a distúrbios metabólicos, alterações funcionais e/ou estruturais de órgãos-alvo, sendo agravada pela presença de outros fatores de risco (sociedade brasileira de cardiologia, 2016). O diabetes mellitus é uma doença caracterizada pela elevação da glicose no sangue (hiperglicemia). Pode ocorrer devido a defeitos na secreção ou na ação do hormônio insulina (sociedade brasileira de diabetes, 2016). Sendo ambas dent de grande importância no território nacional, uma das possibilidades para abordar os diabéticos e hipertensos é o projeto de saúde no território (pst), que consiste em uma estratégia de orientação e organização do trabalho de equipes de saúde por meio da discussão das necessidades de saúde no território. Isso reduz as vulnerabilidades em determinado território, com atuação de esf/nasf, de outros serviços e de parcerias, investindo na qualidade de vida e protagonismo de sujeitos e comunidades, além de promover a saúde e prevenir complicações (silva, 2016). A pesquisa objetivou caracterizar o perfil da comunidade e identificar a abrangência da hipertensão arterial sistêmica e da diabete mellitus na comunidade estudada.

\section{METODOLOGIA}

Foi realizado um estudo descritivo por meio de levantamento de dados dos cadernos de campo da acs's nos quais foram coletadas informações sobre o controle de diabéticos e hipertensos de cada microárea, além dos dados dos mapas, atualizados em setembro de 2017. Foram observadas as 7 microáreas da equipe lua da unidade atendimento primário à saúde dr. José cláudio arpini, em patos de minas, minas gerais e elaborados gráficos e tabelas para a comparação dos dados encontrados nas microáreas e os dados nacionais.

\section{RESULTADOS E DISCUSSÃO}

Segundo a pesquisa nacional de saúde de 2013 (pns, 2013), a hipertensão arterial foi a dcnt mais referida, com prevalência de 21,4\% na população de pessoas de 18 anos ou mais de idade. A pns (2013) revelou que a carga de morbidade das dent no país é elevada, cerca de $45 \%$ da população declara pelo menos uma doença crônica, se caracterizando como o problema de saúde pública de maior magnitude, uma vez que correspondem à maior proporção das causas de morte no país. O diabetes mellitus é um problema de saúde global, no brasil, a pns (2013) revelou dados de acometimento de cerca de $6,2 \%$ da população. 
Tabela 1 - número de diabéticos e hipertensos por microárea

\begin{tabular}{lccccccc}
\hline \multicolumn{1}{c}{ Microárea } & $\mathbf{1}$ & $\mathbf{2}$ & $\mathbf{3}$ & $\mathbf{4}$ & $\mathbf{5}$ & $\mathbf{6}$ & $\mathbf{7}$ \\
\hline $\mathbf{N}^{\circ}$ Famílias & 183 & 179 & 163 & 209 & 195 & 168 & 238 \\
$\mathbf{N}^{\circ}$ Pessoas & 605 & 527 & 576 & 666 & 538 & 531 & 693 \\
$\mathbf{N}^{\circ}$ Diabéticos & 34 & 18 & 48 & 31 & 26 & 25 & 15 \\
$\mathbf{N}^{\mathbf{0}} \mathbf{H A}^{*}$ & 77 & 86 & 138 & 101 & 105 & 94 & 76 \\
\hline
\end{tabular}

*Ha- hipertensão arterial - fonte: caderno agentes comunitárias de saúde, equipe lua - uaps nova floresta

\section{GRÁFICO 1- RELAÇÃO DO NÚMERO DE DIABÉTICOS HIPERTENSOS}

POR MA EM RELAÇÃO A MEDIA NACIONAL

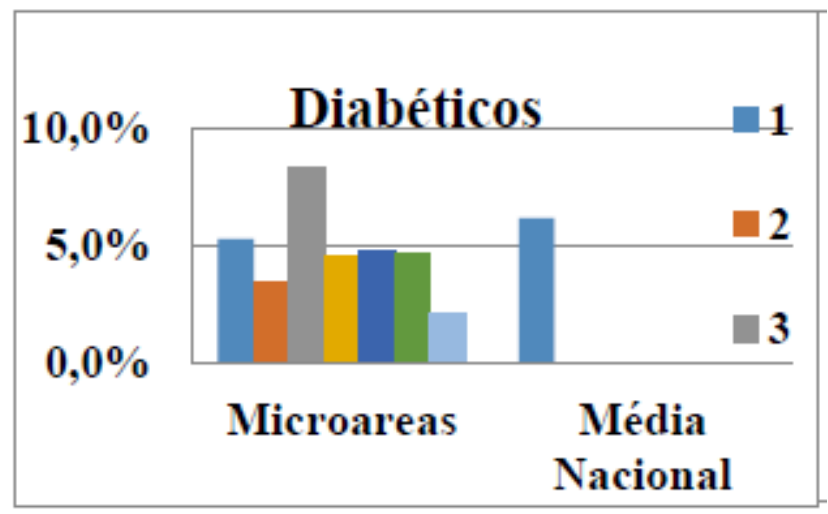

GRÁFICO 2 - RELAÇÃO DO NÚMERO DE POR MA EM RELAÇÃO A MÉDIA NACIONAL

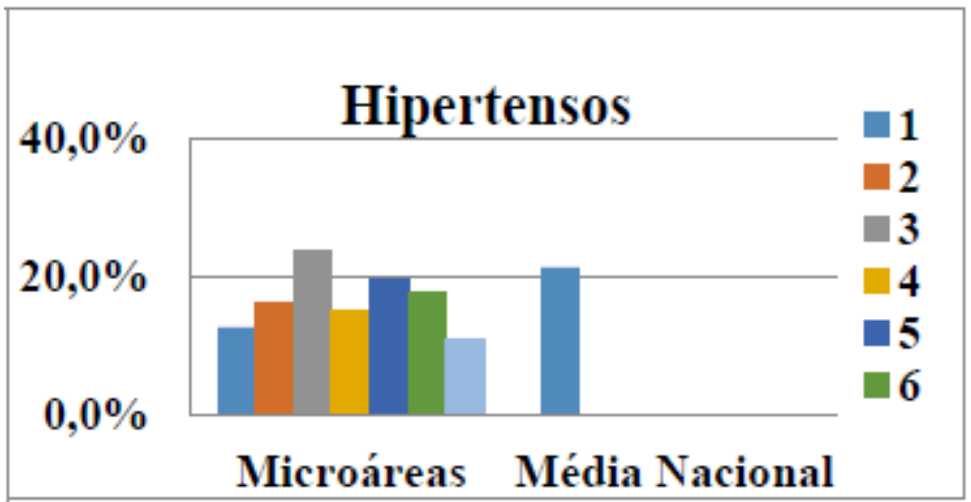

Fonte: Caderno agentes comunitárias de saúde, equipe lua - uaps nova floresta

O índice de pessoas acometidas por microárea é, em geral, menor do que a média nacional, com exceção da ma 3. O aumento do índice das doenças crônicas citadas é reflexo da transição epidemiológica que acontece no brasil. Nota-se o aumento de casos de doenças crônicas, em detrimento da frequência das doenças infecciosas e parasitarias. Nesse sentido, o sus, em especial no contexto da saúde básica, deverá sentir os impactos dessa transição, o que demandará esforços para 
a adaptação nesse novo cenário. Em razão disso, é compreensível que a população, nessa nova fase, possa ser prejudicada a permanência do processo de aumento desses números, refletindo diretamente na qualidade de vida brasileira, dependendo de como for o processo de adaptação das equipes de saúde (mendes, 2012).

\section{CONCLUSÃO}

Conclui-se que, em geral, os valores encontrados entre a população atendida foram menor que a média nacional, com exceção de uma microárea. Sendo assim, sugere-se a averiguação do motivo, apontando como primeira hipótese a faixa etária, já que a m3 é formada por uma população predominantemente idosa. Destaca-se a importância do pst na atenção primária para o desenvolvimento de ações de promoção de saúde e controle dos fatores de risco associados às dcnt mais prevalentes na população. 


\section{REFERÊNCIAS}

Sociedade brasileira de cardiologia; 7a diretriz brasileira de hipertensão arterial; arquivos brasileiros de cardiologia; volume 107, no 3, supl. 3, setembro 2016.

Sociedade brasileira de diabetes; diretrizes da sociedade brasileira de diabetes (2015-2016); adolfo milech...[et. Al.]; organização josé egidio paulo de oliveira, sérgio vencio- são paulo: a.c. farmacêutica, 2016.

Brasil- ministério da saúde; pesquisa nacional da saúde; revista brasileira de epidemiologia, 2015; brasilia- df.

Mendes, e.v; o cuidado das condições crônicas na atenção primária à saúde: o imperativo da consolidação da estratégia da saúde da família. Brasília: organização pan-americana da saúde, 2012. 


\section{Capítulo 3}

d

\section{ESCALA DE COMA DE GLASGOW COM RESPOSTA PUPILAR (ECG-P) E SUA RELAÇÃO COM O PROGNÓSTICO DE PACIENTES COM TCE: UMA REVISÃO DA LITERATURA}

BÁRBARA ANDRESSA SILVA FERREIRA

AMANDA ROCHA DORNELES

FERNANDA BEATRIZ GALVANI

GUILHERME CINCINATO DE ALMEIDA

ISADORA ALMEIDA COUTO

LOUISE OLIVEIRA PEREIRA

LUANA ASSUNÇÃO FIALHO

RAFAEL PEREIRA DE AMORIM

TIAGO GUIMARÃES REIS

NATALIA DE FATIMA GONÇALVES AMANCIO
CENTRO UNIVERSITARIO DE PATOS DE MINAS - UNIPAM

CENTRO UNIVERSITARIO DE PATOS DE MINAS - UNIPAM

CENTRO UNIVERSITARIO DE PATOS DE MINAS - UNIPAM

CENTRO UNIVERSITARIO DE PATOS DE MINAS - UNIPAM

CENTRO UNIVERSITARIO DE PATOS DE MINAS - UNIPAM

CENTRO UNIVERSITARIO DE PATOS DE MINAS - UNIPAM

CENTRO UNIVERSITARIO DE PATOS DE MINAS - UNIPAM

CENTRO UNIVERSITARIO DE PATOS DE MINAS - UNIPAM

CENTRO UNIVERSITARIO DE PATOS DE MINAS - UNIPAM

CENTRO UNIVERSITARIO DE PATOS DE MINAS - UNIPAM 
Resumo: Introdução: Traumatismo crânio-encefálico (TCE) é uma das maiores causas de morte no mundo. Mais da metade dos traumatizados morrem nos primeiros momentos após o acidente. Contudo, a triagem inicial envolvendo a avaliação neurológica, pode interferir nesse prognóstico. Por isso existem várias escalas de avaliação de consciência, sendo a mais utilizada a Escala de Coma de Glasgow, que sofreu atualização em 2018, e se tornou a Escala de Coma de Glasgow com Resposta Pupilar (ECG-P). Objetivos: A fim de contribuir com a atualização dos profissionais de saúde, objetivouse descrever a nova escala e a sua relação com o prognóstico do TCE. Metodologia de Busca: Trata-se de uma revisão da literatura. Consultando as bases Biblioteca Virtual de Saúde (BVS), Google Acadêmico, PubMed, Scielo, e o portal da Sociedade Brasileira de Neurocirurgia, com os descritores "glasgow", "pupila" e "traumatismo", nos idiomas inglês e português, foram selecionados 5 artigos científicos publicados entre os anos 2011 a 2018. Discussão: Os artigos trouxeram a nova Escala de Glasgow, que incluiu a Pontuação de Reatividade Pupilar (PRP). Ela foi modificada a partir da observação de que essa resposta à luz ajuda na estratificação de risco do paciente e consequentemente no seu prognóstico. No novo parâmetro, deve ser feita a subtração da PRP, e o escore vai de 1 a 15. Conclusão: A partir da análise, afirma-se a importância da atualização da Escala de Glasgow na relação com os desfechos de TCE. Por isso deve ser incentivado o conhecimento do assunto e a adesão de médicos e socorristas.

Palavras-chave: Glasgow, Pupila, Traumatismo. 


\section{INTRODUÇÃO}

Os traumas cranioencefálicos (TCE) são um dos principais problemas de saúde pública mundial. É considerada a terceira causa mais comum de óbito nos Estados Unidos (EUA), e no Brasil estima-se que provoca mais de 100.000 vítimas fatais por ano (OLIVEIRA, 2014).

É fato que mais da metade das vitimas do TCE morrem ainda no local do trauma, sem tempo para reanimação. Contudo, a abordagem inicial, incluindo anamnese, exame físico geral e a avaliação neurológica, se feitos de forma rápida e objetiva, tem grande influência no prognóstico daquele paciente (OLIVEIRA, 2014).

Por isso, nas últimas décadas diversas escalas foram criadas para ajudar os profissionais de saúde a realizarem essa avaliação, sendo a mais utilizada internacionalmente a Escala de Coma de Glasgow (ECG).

A ECG foi desenvolvida por Teasdale e Jennet em 1974, na Universidade de Glasgow. É considerado um instrumento clinico, preditivo e sensível para avaliar alterações do nível de consciência, ao abordar três parâmetros: abertura ocular, reação motora e resposta verbal. Cada componente recebe uma pontuação e a nota final varia de 3 a 15 pontos (MUNÃNA- RODRÍGUEZA, 2014).

A escala já sofreu algumas alterações ao longo dos anos, e em 2018, para sensibilizar ainda mais o teste, foi adicionado a Pontuação de Reatividade Pupilar (PRP) e criado a Escala de Coma de Glasgow com Resposta Pupilar (ECG-P). (SOCIEDADE BRASILEIRA DE NEUROCIRURGIA, 2018)

\section{OBJETIVOS}

Devido à importância dessa escala nas urgências para a avaliação de traumas cranioencefálicos (TCE), objetivou-se descrever a nova Escala de Coma de Glasgow com Resposta Pupilar (ECG-P) e sua relação com a avaliação de prognóstico de pacientes com TCE, a fim de contribuir com a atualização de médicos, estudantes e outros profissionais da área da saúde.

\section{METODOLOGIA DE BUSCA}

Trata-se de revisão da literatura, que buscou evidenciar e discutir as principais características nova Escala de Coma de Glasgow com Resposta Pupilar (ECG-P), bem como suas contribuições para o prognóstico de pacientes com TCE, a partir de publicações científicas indexadas na base de dados Biblioteca Virtual de Saúde (BVS), Google Acadêmico, PubMed, Scielo, e o portal da Sociedade Brasileira de Neurocirurgia, entre os anos de 2011 a 2018. Foram utilizados os descritores "glasgow", 
"pupila" e "traumatismo", nos idiomas inglês e português. Ao final, foram selecionados 05 artigos, sendo que destes, dois eram no idioma inglês, dois em português e um em espanhol.

\section{DISCUSSÃO}

Segundo a Sociedade Brasileira de Neurocirurgia (SBN) a Escala de Coma de Glasgow (ECG) é o padrãoouro de avaliação de traumatismos cranioencefálicos (TCE) devido à sua simplicidade e praticidade em comparação com outras ferramentas. É recomendado que a primeira avaliação seja feita ainda nas primeiras 6 horas após o trauma, tendo em vista que nas primeiras horas após o acidente, muitos pacientes estão sedados ou intubados, o que poderia interferir no nível de consciência (OLIVEIRA, 2014).

Além disso, a Sociedade relembra o comportamento simples, e que já é rotina de muitos médicos, de fazer o exame de resposta das pupilas à luz.

O estudo de EMAMI et al., (2017), que tem como um dos colaboradores um dos criadores da Escala de Coma de Glasgow; confirmou a maior precisão de diagnóstico e de possíveis prognósticos do TCE, a associação da ECG com a avaliação da resposta pupilar à luz.

Nessa pesquisa foram unidos dois grandes estudos o CRASH (Corticosteroid Randomisation After Significant Head Injury; $n=9,045$ ) e o IMPACT (International Mission for Prognosis and Clinical Trials in TBI; $n=6855$ ) somando ao todo informações de 15.900 pacientes que sofreram traumatismo cranioencefálico e que foram tratados nos anos de 2002 a 2013 em hospitais alemães (EMAMI et al., 2017).

Foram excluídos aqueles que morreram, quem tinha mais de 55 anos, devido a maior taxa de mortalidade de idosos com TCE; aqueles que transferiram de hospital e aqueles que tinham dados incompletos, ficando, ao final, informações de 9559 pacientes para serem analisadas. Além disso, eles ainda os classificaram em pediátricos (até 15 anos de idade) e adultos (até 55 anos de idade), sendo que a maior causa de trauma naqueles foi acidentes automobilísticos e nesses ferimentos como pedestres (EMAMI et al., 2017).

A gravidade do TCE e a alteração da consciência foram pontuados usando o ECG, mais detalhada na Tabela 1, avaliando a resposta motora de 1 a 6 , resposta verbal de 1 a 5 e abertura ocular de 1 a 4 e também pelo Eppendorf-Cologne Scale (ESC). Esse último (Tabela 2), é um novo escore de trauma que combina reatividade da pupila pontuando de 0 a 3, seu tamanho de 0 a 2 pontos e um componente motor adaptado da ECG que varia de 0 a 3. 
TABELA 1 - Escala de Coma de Glasgow (ECG)

\begin{tabular}{|c|c|c|}
\hline & Variáveis & Escore \\
\hline \multirow[t]{8}{*}{ Abertura ocular } & Espontänea & 4 \\
\hline & A voz (comando verbal) & 3 \\
\hline & A dor & 2 \\
\hline & Ausente & 1 \\
\hline & Näo testável (NT) - Em & \\
\hline & pacientes com edema ou & \\
\hline & hematoma que impossibilita & \\
\hline & a abertura dos olhos. & \\
\hline \multirow[t]{8}{*}{ Melhor resposta verbal } & Orientado & 5 \\
\hline & Confuso & 4 \\
\hline & Palavras inapropriadas & 3 \\
\hline & Palavras ou sons & 2 \\
\hline & incompreensivos & 1 \\
\hline & Sem resposta & \\
\hline & Näo testáved (NT) - Em & \\
\hline & pacientes intubados & \\
\hline \multirow[t]{6}{*}{ Resposta motora } & Obedece a comanders & 6 \\
\hline & Localiza dor & 5 \\
\hline & Movimento de retirada à dor & 4 \\
\hline & Flexĩo anormal & 3 \\
\hline & Extensio anormal & 2 \\
\hline & Nenhuma resposta & 1 \\
\hline
\end{tabular}

Fonte: OLIVEIRA, et al., 2014.

TABELA 2 - Eppendorf-Cologne Scale (ESC)

\begin{tabular}{clc}
\hline Element & \multicolumn{1}{c}{ Findings } & Score/Value \\
\hline Motor response & Normal & 0 \\
\cline { 2 - 3 } & Specific & 1 \\
\cline { 2 - 3 } & Nonspecific & 2 \\
\cline { 2 - 3 } & None & 3 \\
\hline Pupil reactivity & Brisk & 0 \\
\cline { 2 - 3 } & Sluggish & 1 \\
\cline { 2 - 3 } & Fixed & 3 \\
\hline Pupil size & Normal & 0 \\
\cline { 2 - 3 } & Anisocoric & 1 \\
\cline { 2 - 3 } & Bilaterally dilated & 2 \\
\hline
\end{tabular}

Fonte: EMAMI et al., 2017.

Os resultados trouxeram que a taxa de morte em geral foi maior em adultos do que crianças $19,9 \%$ vs $16,3 \%$ respectivamente e que esse resultado também se demonstrou nas primeiras 24 hs $11,1 \%$ vs $9 \%$. Os achados foram concordantes com alguns estudos que mostram que pacientes pediátricos com TCE têm um melhor prognóstico que pacientes adultos, demonstrado nas Figuras 3 e 4, o que justifica ações mais drásticas de reanimação nessa faixa etária (EMAMI et al., 2017). 
Figura 3 -Porcentagem de mortes de acordo com a ECG.

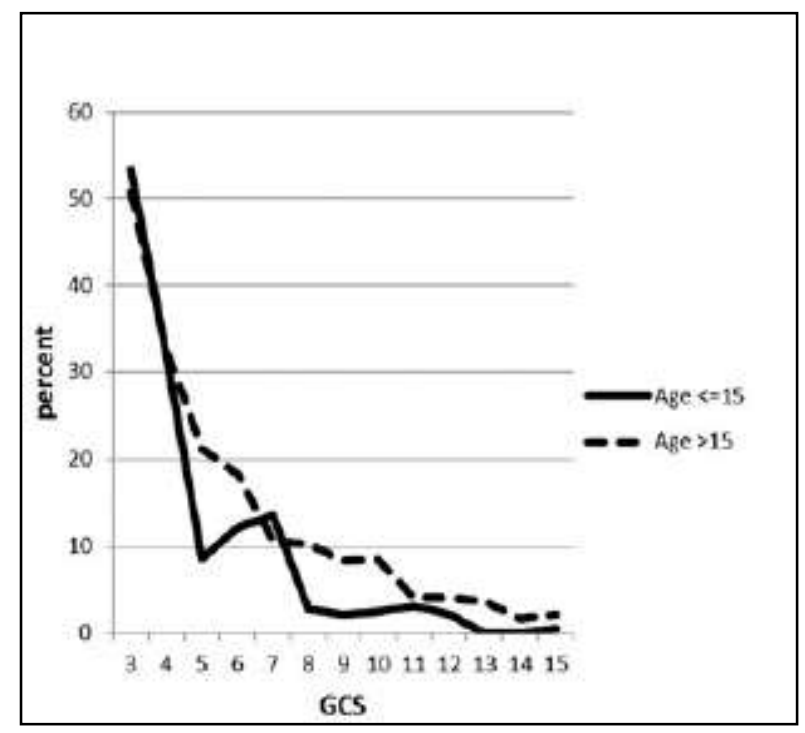

Figura 4: Distribuição do número de pacientes por pontuação na ECG.

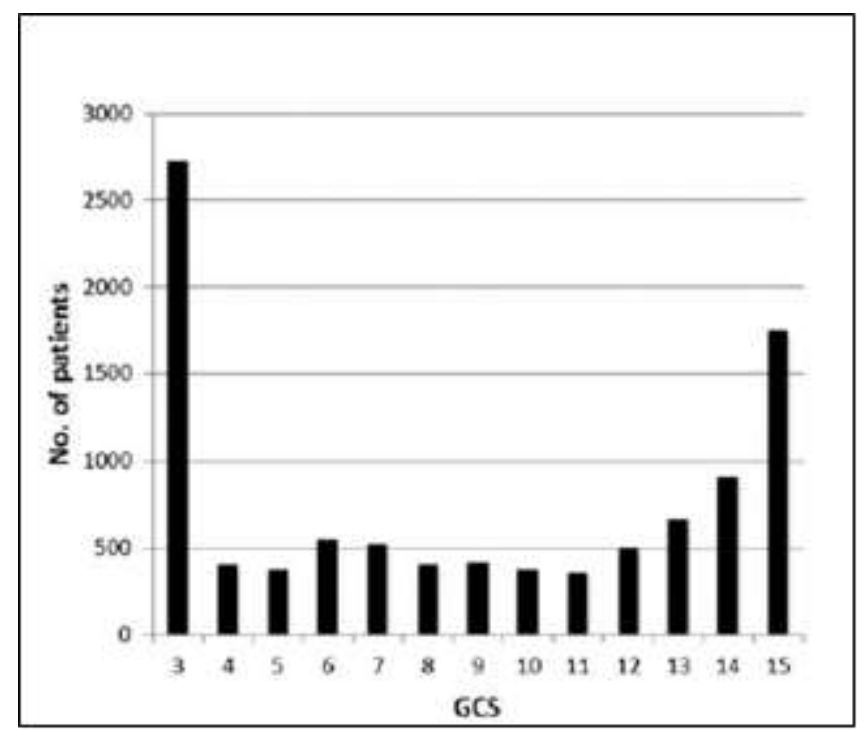

Fonte: EMAMI et al., 2017.

Além disso, ficou demonstrado que avaliações do tamanho e da reatividade pupilar foram ferramentas importantes para a previsão de resultados, demonstrado nas Figuras 5 e 6, sendo que os desfavoráveis aumentaram 63\% quando apenas uma pupila reagia e $79 \%$ quando nenhuma reagia à luz. 
Figura 5: Porcentagem de mortes de acordo com a ECS.

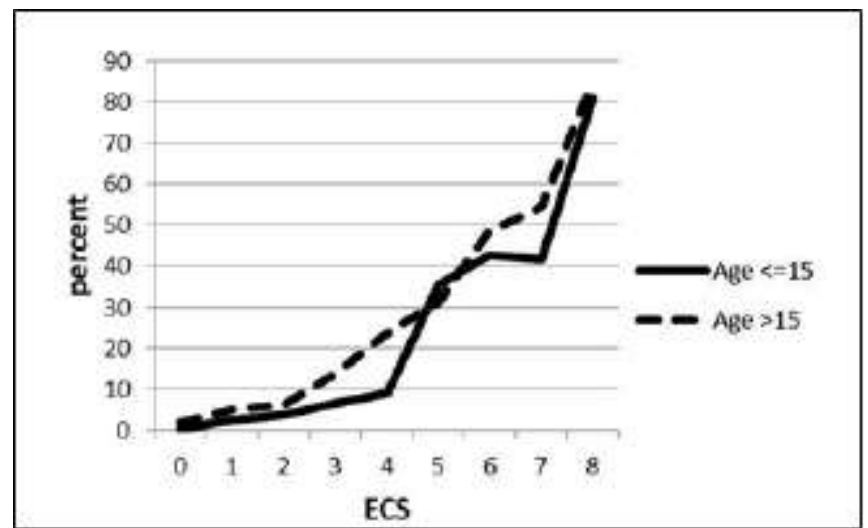

Fonte: EMAMI et al., 2017.

Figura 6: Distribuição do número de pacientes por pontuação na ECS.

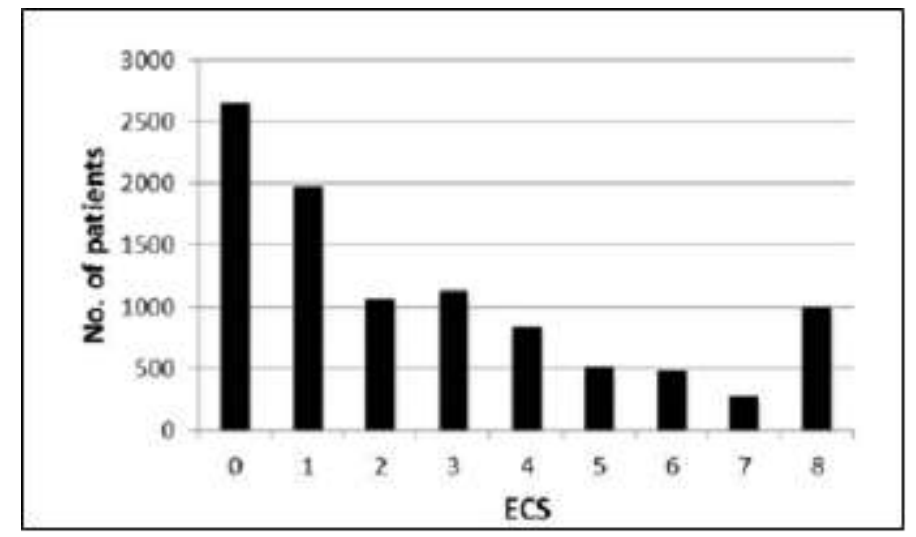

Fonte: EMAMI et al., 2017.

Devido a isso os autores demonstraram a relação da resposta pupilar com o prognóstico de um paciente com TCE, e foi criado a Escala de Coma de Glasgow com Resposta Pupilar (ECG-P). Nela, os profissionais da saúde irão realizar a ECG e desse resultado subtrairão a Pontuação de Responsabilidade Pupilar, descrita na Tabela 3. O escore final irá variar de 1 a 15 (EMAMI et al., 2017).

TABELA 3 - Pontuação de Responsabilidade Pupilar

\begin{tabular}{cc}
\hline REATIVIDADE PUPILAR & PONTUAÇÃO \\
\hline Inexistente & 2 \\
Parcial & 1 \\
Completa & 0
\end{tabular}

Fonte: Adaptada de SOCIEDADE BRASILEIRA DE NEUROCIRURGIA. Escala de coma de Glasgow ganha atualização esclarecedora. Disponível em: < https://portalsbn.org/portal/escala-de-coma-deglasgow-ganha-atualizacao-esclarecedora/> Acesso em: 27 de setembro de 2018. 
Ademais, outro estudo realizado em 2011 com 24115 pacientes internados nos hospitais da Alemanha de 1993 a 2009, demonstrou que a Escala de Coma de Glasgow aliada com a resposta pupilar presente no ECS superou a precisão diagnóstica da ECG isoladamente, pois 95,1\% dos 283 pacientes que tinham TCE grave, apresentavam pupilas não reativas ou desiguais à luz, enquanto os que apresentam um traumatismo mais leve, cerca de $8 \%$ do total, mostravam ambas as pupilas reativas (HOFFMANN et al., 2011).

Portanto, devido a simplicidade e a maior precisão diagnóstica, acredita-se que essa nova escala deve ser conhecida e aderida nas urgências pelos médicos e outros profissionais da saúde. (SOCIEDADE BRASILEIRA DE NEUROCIRURGIA, 2018).

\section{CONSIDERAÇÕES FINAIS}

O traumatismo crânio-encefálico é uma condição grave, responsável por altos índices de mortalidade em todo o mundo. A história clinica, o exame físico e a avaliação neurológica são grandes influenciadores do curso desta patologia, o que justifica o grande número de escalas neurológicas criadas nas últimas décadas, sendo a Escala de Coma de Glasgow a mais famosa e mais usada internacionalmente. Por isso, a partir das discussões trazidas pelos artigos, foi possível identificar a importância desse parâmetro e confirmar que um teste simples e rápido, como a resposta da pupila à luz, interfere na classificação de risco do paciente e consequente no seu prognóstico. Por isso, em 2018, essa escala sofreu uma atualização para a Escala de Coma de Glasgow com Resposta Pupilar (ECG-P) que varia de 1 a 15 pontos, e continua trazendo como parâmetros a avaliação da abertura ocular, resposta verbal, resposta motora, além da Pontuação de Responsabilidade Pupilar, que deve ser subtraído da soma total dos outros índices. Assim, é possível concluir que a Escala de Coma de Glasgow com Resposta Pupilar (ECG-P) foi uma importante mudança, que aliados a outros métodos, garante uma maior sensibilidade no diagnóstico e prognóstico dos traumatismos crânio-encefálicos, principalmente os mais graves. Devido a sua simplicidade e importância, acredita-se que ela será bem aderida aos serviços de urgência e emergência. 


\section{REFERÊNCIAS:}

1. EMAMI, P. M.D.T. et al. Impact of Glasgow Coma Scale score and pupil parameters on mortality rate and outcome in pediatric and adult severe traumatic brain injury: a retrospective, multicenter cohort study. Journal Neurosurg, USA, 2017. v. 126 p. 760-767.

2. HOFFMANN. M et al. Pupil evaluation in addition to Glasgow Coma Scale components in prediction of traumatic brain injury and mortality. British Journal of Surgery Society Ltd, England, 2011.

3. MUÑANA-RODRÍGUEZ, J. E. et al. Escala de coma de Glasgow: origen, análisis y uso apropiado. Enfermería Universitaria, México, 2014.

4. OLIVEIRA, D.M.P. et al. Escalas para avaliação do nível de consciência em trauma cranioencefálico e sua relevância para a prática de enfermagem em neurocirurgia. Arquivos brasileiros de neurocirurgia, Aracajú, 2014. 33(1) p. 22-32.

5. SOCIEDADE BRASILEIRA DE NEUROCIRURGIA. Escala de coma de Glasgow ganha atualização esclarecedora. Disponível em: < https://portalsbn.org/portal/escala-de-coma-de-glasgow-ganhaatualizacao-esclarecedora/> Acesso em: 27 de setembro de 2018. 


\section{Capítulo 4}

d.)

\section{DISTOCIA DE OMBRO E A PRÁTICA DA ASSISTÊNCIA HUMANIZADA AO PARTO}

Lia Francisco Paiva Baía

Victória Eler Fava

Ariana Pinheiro Caldas

Camila Soares de Almeida

Marcelo de Figueiredo Murta

Maria Alice Boareto Freitas
Universidade Vale do Rio Doce

Universidade Vale do Rio Doce

Universidade Vale do Rio Doce

Universidade Vale do Rio Doce

Residência em GO no Hospital Sofia Feldman e residência em Mastologia no Instituto Mario Penna $\mathrm{BH}$

Universidade Federal de Rondônia 
Resumo: Introdução: a distocia de ombro (do) é uma emergência obstétrica que ocorre durante o período de expulsão do concepto e é conhecida por sua imprevisibilidade, sendo uma das emergências intraparto mais temidas. Objetivo: promover uma revisão bibliográfica útil na orientação da assistência ao parto ao ocorrer distocia de ombros, apresentando estratégias adequadas de diagnóstico e manejo de forma segura e humanizada. Metodologia: revisão bibliográfica sistemática e seletiva do tema "distocia de ombros" em bases de dados como pubmed, scielo e livros renomados de obstetrícia. Discussão: emergências obstétricas para distocia de ombro, chegam a 0,6 a 1,4\% de todos os partos vaginais, apresentando fatores de risco e consequências maternas e fetais resultado:é determinado pelas diretrizes e literaturas obstétricas que o diagnóstico da do é feito durante a fase de expulsão no trabalho de parto. Não há como identificar essa patologia em qualquer momento antes do período expulsivo pois é devido a uma falha na rotação externa que os ombros do feto se prendem ao diâmetro formado pela púbis e o promontório materno. Conclusão: percebe-se que a distocia de ombros, apesar de ser imprevisível e temida, pode apresentar bom prognóstico, desde que o médico responsável pela assistência ao parto esteja preparado junto com sua equipe obstétrica. Além disso, a participação ativa da gestante é fundamental para a boa evolução do quadro, deixando-a ciente da situação, que seja acalmada e instruída a cooperar com as mudanças de posição ou demais condutas que necessitem ser estabelecidas.

Palavras-chave: Distocia de ombro; parto humanizado; emergência; assistência ao parto. 


\section{INTRODUÇÃO}

A distocia de ombro (do) é uma emergência obstétrica que ocorre durante o período de expulsão do concepto e é conhecida por sua imprevisibilidade, sendo uma das emergências intraparto mais temidas. O termo "distocia" se refere à anormalidades materno-fetais que impeçam ou comprometam o parto. No caso da do essa alteração consiste na parada da expulsão fetal devido à impactação do concepto por seu diâmetro biacromial que fica preso entre a sínfise púbica e o promontório sacral da mãe, sendo necessário a realização de manobras de desprendimento que variam desde a mudança de posição materna ou medidas não invasivas à medidas invasivas. A conduta deve seguir uma sequência bem estruturada, conferindo-se a eficiência das manobras aplicadas e sempre com o auxílio de uma equipe experiente (montenegro; rezende filho, 2016).

A do requer uma intervenção imediata com manobras obstétricas respaldadas em evidências científicas, o que atende aos pilares da assistência humanizada. (amorim et al., 2013; afonso et al., 2017)

\section{OBJETIVO}

O presente trabalho visa agrupar conhecimentos de diferentes e confiáveis literaturas a fim de promover uma revisão bibliográfica que seja útil na orientação da assistência ao parto no caso de distocia de ombros. Além disso, objetiva-se proporcionar uma reflexão sobre a forma como os profissionais lidam com esta emergência, incentivando um parto humanizado mesmo durante esta situação delicada. Nesse sentido, o objetivo final do artigo é conciliar estratégias adequadas de diagnóstico e manejo da do que sejam igualmente seguras e o mais humanizadas possível.

\section{METODOLOGIA}

Revisão bibliográfica sistemática e seletiva do tema "distocia de ombros" em bases de dados e livros renomados de obstetrícia, além de leitura de relatos de caso dentro do tema. Assim, o trabalho organizado etapa a etapa, seguindo a seguinte sequência:

1. Definição do tema e seus objetivos

2. Busca de artigos científicos e relatos de caso relevantes em bases de dados, utilizando descritores: "distócia de ombros"; "parto humanizado"; "emergência obstétrica". Busca do tema em literaturas renomadas na obstetrícia. 
3. Seleção dos artigos relevantes, sendo utilizados neste trabalho referências que foram préselecionadas. Os critérios de exclusão foram fuga ao tema, baixa confiabilidade, ou artigos desatualizados.

4. Organização das informações encontradas, estruturação dos tópicos, discussão do tema entre os autores e finalmente a escrita do artigo em si.

\section{DISCUSSÃO}

\section{EPIDEMIOLOGIA E FATORES DE RISCO}

Emergências obstétricas para distocia de ombro chegam a 0,6 a 1,4\% de todos os partos vaginais. Entre os fatores de risco para distocia de ombro, podemos encontrar a macrossomia (é o mais significante), diabetes pré-gestacional e gestacional, história prévia de distocia de ombro e parto vaginal operatório com uso de aspirador (davis et al., 2020; menticoglou, 2018; spong et al., 1995; allen, 2017; ribeiro et a. 2017).

Dentre as consequências, podemos citar as maternas e fetais após a distocia de ombro. As consequências maternas incluem hemorragia pós-parto, além do risco aumentado de lacerações de terceiro ou quarto grau. Dentre as consequências fetais existem as lesões do plexo braquial fetal, na qual pode levar a plexopatias braquiais obstétricas, como paralisia de erb ou klumpke (merryman; varacallo, 2021; davis et al., 2020; menticoglou, 2018).

Outras consequências fetais envolvem fratura clavicular ou do úmero fetal, síndrome da encefalopatia isquêmica hipóxica e até morte fetal (davis et al., 2020; menticoglou, 2018). Das plexopatias braquiais obstétricas, as lesões superiores são as mais comuns. Lesões superiores resultam de uma flexão lateral da cabeça para longe do ombro afetado, com depressão do ombro ipsilateral resultando em uma deficiência de c5-6. Lesões inferiores são causadas por tração com o ombro em abdução total no momento do parto, envolvendo c8-t1 (merryman; varacallo, 2021; davis et al., 2020; menticoglou, 2018).

As plexopatias braquiais totais são a forma mais rara de plexopatias obstétricas e são causadas por um estiramento grave ou lesão do tipo avulsão, 
Envolvendo c5-t1. De acordo com a oms, lesões do plexo braquial se apresentam em 1,3\%; desses $61,8 \%$ eram supraclaviculares e $38,2 \%$ eram infra-claviculares c8 a t1 (merryman; varacallo, 2021; davis et al., 2020; menticoglou, 2018; spong et al., 1995).

Os acidentes supraclaviculares têm graus mais elevados de dano neurológico com base na classificação de sunderland, enquanto as lesões infraclaviculares resultam em neuropraxia com mais frequência. Dessa forma, todos os profissionais da obstetrícia devem ter conhecimento sobre os fatores de risco e o manejo da distocia de ombro (davis et al., 2020; menticoglou, 2018; spong et al., 1995; allen et al., 2017).

\section{MECANISMOS DO PARTO}

Apesar de conhecermos os fatores de riscos associados à do, estes não são suficientes para estabelecer o diagnóstico. É determinado pelas diretrizes e literaturas obstétricas que o diagnóstico da do é feito durante a fase de expulsão no trabalho de parto. Não há como identificar essa patologia em qualquer momento antes do período expulsivo pois é devido a uma falha na rotação externa que os ombros do feto se prendem ao diâmetro formado pela púbis e o promontório materno (montenegro; rezende filho, 2016; zugaib; francisco, 2020).

Para entender a ocorrência dessa patologia, é relevante que se conheça os mecanismos de parto com entendimento dos movimentos realizados pelo concepto durante o período expulsivo. São estes: insinuação; descida; flexão; rotação interna; deflexão; rotação externa; desprendimento de ombros (montenegro; rezende filho, 2016; zugaib; francisco, 2020).

\subsection{INSINUAÇÃO}

Se define pela passagem do concepto (o maior diâmetro de sua apresentação

- Seja cefálica ou pélvica) pelo estreito superior da bacia. A referência para se afirmar que o feto está insinuado é o plano 0 de delee, ou seja, a nível de espinhas isquiáticas. Essa informação pode ser constatada pelo toque e complementada pela 4a manobra de leopold que verifica a altura da apresentação, dizendo se está no plano 0 de delee ou não (montenegro; rezende filho, 2016; zugaib; francisco, 2020). 


\subsection{DESCIDA}

Na descida há a transposição da bacia média para a bacia inferior, ou seja, observa-se um avanço do plano de delee. É importante frisar que essas divisões são didáticas e ocorrem em conjunto ou com linha tênue de diferença de tempo entre os movimentos, de forma que um movimento ajuda o outro a ocorrer (montenegro; rezende filho, 2016; zugaib; francisco, 2020).

\subsection{FLEXÃO}

É importante que o feto esteja fletido para que o menor diâmetro cefálico seja apresentado e passe pela conjugata obstétrica, que possui cerca de $10 \mathrm{~cm}$. A flexão habitual garante o diâmetro diâmetro - subocciptobregmático - o qual tem $9,5 \mathrm{~cm}$ e, portanto, passa adequadamente por uma pelve normal. No feto fletido é notada a palpação do vértice durante o toque feito após a descida (zugaib; francisco, 2020).

Quando há anormalidades na flexão, estamos diante de um feto defletido, o que pode se dispor em vários graus. A deflexão de 1으 grau tem por referência o bregma. A deflexão de 2 o grau tem por referência a fronte e apresenta o maior diâmetro - occipito mentoniano, e por isso é a única que impede a saída fetal. Já a de 3o grau tem a face como referência (zugaib; francisco, 2020).

\subsection{ROTAÇÃO INTERNA}

Neste movimento a cabeça fetal faz um movimento rotacional de forma que, fisiologicamente, o feto fique com a sutura sagital orientada no sentido anteroposterior. Ou seja, encontramos as variedades de posição occiptopúbis (mais frequente) e occitosacral (montenegro; rezende filho, 2016; zugaib; francisco, 2020).

\subsection{DEFLEX̃̃O}

Esse movimento, também chamado de desprendimento do polo cefálico, trata-se de uma das etapas finais do parto. Trata-se da deflexão da cabeça, fazendo com que essa se projete para fora do corpo materno. Mais uma vez vale ressaltar que essa divisão é didática e que na prática, os movimentos ocorrem de forma cooperativa e quase simultânea caso não haja intercorrências (montenegro; rezende filho, 2016; zugaib; francisco, 2020). 


\subsection{ROTAÇÃO EXTERNA}

É a fase em que há a rotação externa da cabeça, mas outro evento também é muito importante, a rotação interna das espáduas. Durante a expulsão, as espáduas ficam posicionadas com o comprimento biacromial de forma oblíqua direita ou transversa. Quando entra nessa etapa do trabalho de parto, elas também sofrem movimento de rotação (por motivos que se assemelham aos do polo cefálico) e passam a se orientar no diâmetro anteroposterior do trajeto (montenegro; rezende filho, 2016; zugaib; francisco, 2020).

\subsection{DESPRENDIMENTO DE OMBROS}

Por fim, é necessário que ocorra o desprendimento dos ombros, sendo que primeiramente se solta o ombro anterior e em seguida o posterior. Quando isso não ocorre de maneira eficiente, é possível tentar realizar uma manobra de tração leve para baixo a fim de ajudar o desprendimento do ombro anterior e depois para cima, para dar continuidade ao posterior (montenegro; rezende filho, 2016; zugaib; francisco, 2020).

\section{DIAGNÓSTICO}

O diagnóstico da do é feito quando, mesmo após tais manobras de desprendimento, o objeto permanece nas vias de parto com a cabeça exteriorizada por 30 segundos ou mais. Outra forma de estabelecer um diagnóstico evidente é o "sinal da tartaruga”. Este sinal é visto com grande frequência nos casos de do e consiste exteriorização da cabeça fetal seguida da sua retração (movimento de "vai, volta e para"), de forma que o rn não consiga continuar a saída do trajeto (montenegro; rezende filho, 2016).

\section{MANEJO HUMANIZADO}

O parto é um acontecimento complexo, capaz de ser marcante no âmbito emocional da gestante ou até mesmo doloroso e traumático. Por isso, ofertar boas práticas à mulher é imprescindível e significa dar suporte de qualidade, levando em consideração o conforto tanto físico como emocional, respeitando e colaborando na forma como ela deseja parir e, especialmente, oferecendo-lhe técnicas capazes de atenuar suas queixas álgicas (amorim et al., 2013).

A partir disso, o uso de mnemônicos na prática clínica em casos de emergências, como na distocia de ombros, é significativo no sucesso e na humanização do parto, visto que tais práticas são baseadas em evidências médicas, diminuindo, assim, a ocorrência de complicações (amorim et al., 2013). 
Dessa forma, citamos o mnemônico "aleerta", bastante utilizado no meio médico, em que significa:

I. "a" significa chamar ajuda, sempre do profissional mais experiente e de uma equipe bem preparada. Além disso, deve-se avisar a parturiente acerca do contratempo do parto, para que assim ela possa colaborar e compreender a importância da assistência prestada. Ainda nesse tópico, devemos lembrar de deixar um anestesista a postos, para agir rapidamente caso seja necessário fazer episiotomia (reis et al., 2019; amorim et al., 2013).

II. "I" significa levantar os membros inferiores em hiperflexão, em direção ao abdome, que irá endireitar o sacro na coluna lombar - manobra de mcroberts (reis et al., 2019; amorim et al., 2013).

III. A primeira letra "e" significa pressão externa na região supra púbica, de forma descendente, e seu objetivo é diminuir o diâmetro bisacromial fetal pela adução do ombro fetal anterior (reis et al., 2019; amorim et al., 2013).

IV. A segunda letra "e" significa considerar a realização de episiotomia. Esta, em muitos estudos recentes, não mostra efetividade na prevenção de lesões obstétricas anais, além de algumas posições realizadas para solucionar o caso, como a vertical ou gaskin, serem eficazes na redução do uso da episiotomia. Portanto, esse procedimento deve ser avaliado de forma criteriosa, lembrando que toda episiotomia já é uma laceração de 2 grau - cabe ao obstetra avaliar se há necessidade de evitar lacerações de 3 으 ou 4ํ grau e se a episiotomia será eficaz ou não. Essa postura crítica e atenciosa está preconizada dentro da assistência humanizada ao parto (reis et al., 2019; amorim et al., 2013; souza et al., 2020).

V. " $r$ " significa remover o braço posterior, o obstetra desliza a mão ao longo do ombro e braço posteriores do feto, e o antebraço ou punho fetal é agarrado e movimentado por meio do tórax fetal anterior para efetuar o lançamento do braço posterior. Se o antebraço fetal não for facilmente acessível, pode-se seguir o braço fetal posterior e colocar pressão na fossa antecubital, o que normalmente levará à flexão do braço fetal, permitindo acesso ao antebraço fetal. Com a liberação bem-sucedida do braço posterior, o diâmetro axilo-acromial torna-se a parte de apresentação e é tipicamente cerca de $3 \mathrm{~cm}$ mais curto e leva à liberação do ombro anterior (reis et al., 2019; amorim et al., 2013).

VI. " $\mathrm{t}$ " significa realização de toque para manobras internas, como a de rubin ii, em que se aplica pressão no aspecto posterior do ombro fetal mais acessível em direção ao tórax fetal, levando 
à adução do ombro fetal, o que permitirá que o ombro anterior gire e saia de trás do osso púbico, onde é impactado e a de woods, em que o obstetra coloca a mão na face anterior do ombro fetal posterior e gira o ombro em direção às costas do feto. $O$ objetivo é tentar girar o ombro fetal em 180 graus, permitindo que o feto desça enquanto a rotação está ocorrendo (reis et al., 2019; amorim et al., 2013).

VII. Por fim, a letra "a" significa alterar a posição da gestante, colocando-a em quatro apoios (manobra de gaskin), assim, uma tração suave para baixo é aplicada no ombro posterior (o ombro contra o sacro materno) ou uma tração para cima é aplicada no ombro anterior (o ombro contra a sínfise materna) (reis et al., 2019; amorim et al., 2013).

Primeiramente, deve-se considerar as manobras menos traumáticas visto que são bastante eficazes, resolvendo cerca de $90 \%$ dos casos, isto é, as manobras de hiperflexão (ex.: mcroberts), pressão suprapúbica, mudança de posição para a de quatro apoios, realização de manobras internas (ex.: woods e rubin ii) e, se ainda assim não houver resolução do quadro, se começa a pensar em episiotomia, visto que é uma técnica com pior prognóstico em relação a lacerações de terceiro e quarto grau (amorim et al., 2013; afonso et al., 2017). 


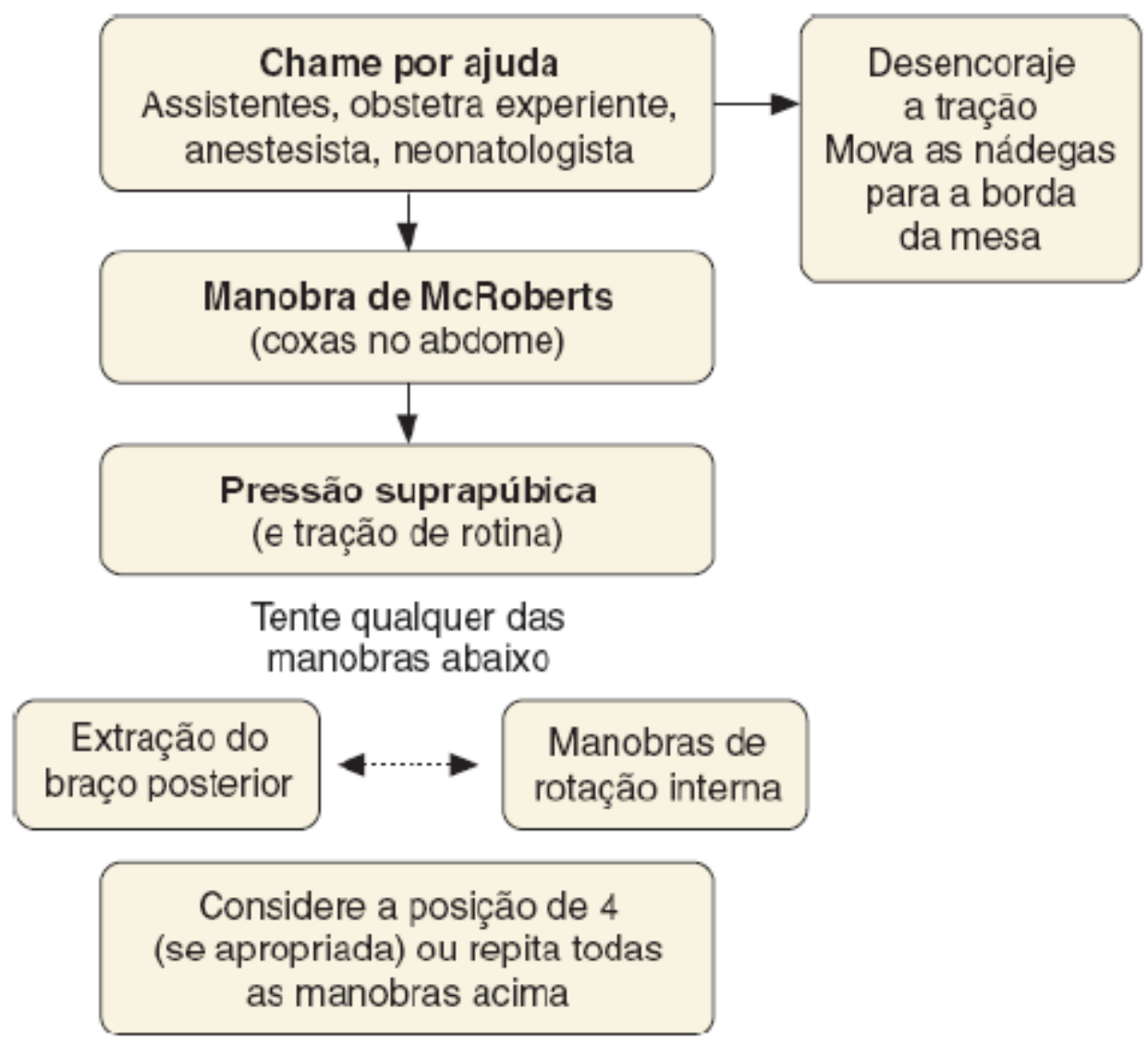

FONTE: MONTENEGRO; REZENDE FILHO, 2017.

\section{CUIDADOS IMEDIATAMENTE APÓS O PARTO}

Não é possível perder de foco cuidados pós parto que são inerentes de todos os partos via vaginal e que devem ser realizados também após os partos com do.

O primeiro cuidado é referente ao 3o período, a dequitação. Nele deve ser feito o auxílio da saída da placenta por meio da tração controlada da placenta, e administração de ocitocina ev, mantendo a mãe orientada (montenegro; rezende filho, 2016; zugaib; francisco, 2020).

Outro cuidado é conferir se houve laceração do trajeto do parto, mesmo que a do não signifique necessariamente a ocorrência de laceração. É preconizado, nos casos de laceração que seja feita a rafia da lesão com anestesia, seguida de revisão do canal e toque retal a fim de garantir que não huve lesão da mucosa retal ou do esfíncter anal (montenegro; rezende filho, 2016; zugaib; francisco, 2020). Avaliar a efetividade do 4 o período e seus mecanismos de hemostasia, palpando o útero para confirmar a formação do globo de pinard e orientando a mãe a observar se há grande volume de sangramento no pós parto e comunicar anormalidades, o que deve ser observado também pela equipe de saúde enquanto a paciente estiver na internação (montenegro; rezende filho, 2016). 
Destaca-se ainda a importância do diálogo entre médico e paciente a fim de explicar a transcorrência do parto e do segmento, o que além de garantir maior vínculo e confiança entre médico e paciente, garante um puerpério mais favorável tanto para a mãe quanto para o bebê (montenegro; rezende filho, 2016).

\section{CONCLUSÃO}

Portanto, a partir da discussão realizada, percebe-se que a distocia de ombros, apesar de ser imprevisível e temida, pode apresentar bom prognóstico em muitos casos, desde que o médico responsável pela assistência ao parto esteja preparado, tenha um conhecimento bem sedimentado sobre os mecanismos do parto e esteja acompanhado de uma equipe bem instruída e devidamente treinada. Salienta-se o mnemônico "aleerta" no manejo dessa complicação, bem como a prática das manobras de forma efetiva, com duração adequada de tempo e conferindo se foram corretamente executadas.

Além disso, nota-se que a participação ativa da gestante é fundamental para a boa evolução do quadro. Dessa forma, é importante que ela esteja ciente da situação, que seja acalmada e instruída a cooperar com as mudanças de posição ou demais condutas que necessitem ser estabelecidas.

Destaca-se também que a episiotomia deve ser criteriosamente avaliada uma vez que não confere melhor prognóstico, apenas facilita parte do acesso para as manobras, as quais podem ser realizadas na ausência de episiotomia obtendo-se bons resultados.

Por tudo isso, pode ser observado que prestar o devido atendimento à distocia de ombros, levando em consideração a participação da mãe, mantendo uma equipe bem integrada, e avaliando a necessidade ou não de procedimentos mais invasivos é uma prestação de parto humanizado com assistência adequada e respaldada na bibliografia científica e deve, portanto, ser encorajado através de mais treinos práticos e discussões acadêmicas a fim de que seja realizada a intervenção imediata que é preconizada, com manobras obstétricas fundamentadas na medicina baseada em evidências, satisfazendo os pilares da assistência humanizada. 


\section{REFERÊNCIAS}

Afonso, maria carvalho et al . Shoulder dystocia: obstetric maneuvers and its Morbidity. Acta obstet ginecol port, coimbra , v. 11, n. 1, p. 28-33, mar. 2017.

Allen, edith d. Gurewitsch et al. Improving shoulder dystocia management and Outcomes with a targeted quality assurance program. American journal of Perinatology, v. 34, n. 11, p. 1088-1096, 2017.

Amorim, melania maria ramos de et al. Distocia de ombro: proposta de um novo Algoritmo para conduta em partos em posições não supinas. Femina, 2013.

Davis, donald d. Et al. Shoulder dystocia. Statpearls [internet], 2020.

Menticoglou, savas. Shoulder dystocia: incidence, mechanisms, and Management strategies. International journal of women's health, v. 10, p. 723, 2018.

Merryman, justin; varacallo, matthew. Klumpke palsy. Statpearls [internet], 2021.

Montenegro, c. A. B; de, rezende filho. J. Rezende obstetrícia, 13a Edição. Rio de janeiro: grupo gen, 2016.

Montenegro, c. A. B; de, rezende filho. J. Rezende obstetrícia Fundamental, 14ạ edição. Rio de janeiro: grupo gen, 2017.

Reis, zilma silveira nogueira et al. Do we know how to avoid oasis in non-supine Birth positions? A retrospective cohort analysis. Revista brasileira de Ginecologia e obstetrícia, v. 41, p. 581-587, 2019.

Ribeiro, soraia pereira; costa, ricardo barros; dias, clara paz. Macrossomia Neonatal: fatores de risco e complicações pós-parto. Nascer e crescer, porto , V. 26, n. 1, p. 21-30, mar. 2017.

Souza, marcella rocha tavares de et al . Factors related to perineal outcome after Vaginal delivery in primiparas: a cross-sectional study. Rev. Esc. Enferm. Usp, são Paulo , v. 54, 2020 .

Spong, c. Y. Et al. An objective definition of shoulder dystocia: prolonged Head-to-body delivery intervals and/or the use of ancillary obstetric maneuvers.

Obstetrics \& gynecology, v. 86, n. 3, p. 433-436, 1995.

Zugaib, m.; francisco, r.p. v. Zugaib obstetrícia, 4ạ. Ed. - barueri [sp] : Manole, 2020. 


\section{Capítulo 5}

\section{PERFIL E ESTADO DE SAÚDE PÓS-PARTO DOS NASCIDOS VIVOS DE ACORDO COM A FAIXA ETÁRIA MATERNA EM UM HOSPITAL DE REFERÊNCIA EM FORTALEZA-CE}

Jocileide Sales Campos

Amanda Teixeira de Aguiar

Bruna Danielle Paula da Ponte

Marina Costa Campos

Mayara Carvalho Fortes

Juliana Guerreiro Mota

Mariana Ribeiro Moura

Carolina de Paiva Farias

Ana Manuela Diógenes Teixeira

Renata Santos Almeida
Centro Universitario Christus

Centro Universitario Christus

Centro Universitario Christus

Centro Universitario Christus

Centro Universitario Christus

Centro Universitario Christus

Centro Universitario Christus

Centro Universitario Christus

Centro Universitario Christus

Centro Universitario Christus 
Resumo: A gravidez é uma fase de mudanças no âmbito biológico, social, somático e psicológico devendo-se, portanto, observar a importância da correlação entre idade materna e resultados perinatais. A idade da concepção e o acompanhamento assistencial pré e perinatal são fatores que podem interferir no estado de saúde da gestante e, sobretudo, do neonato ao nascimento. Assim, o objetivo desse estudo foi pesquisar a relação do perfil e do estado de saúde pós-parto dos recém-nascidos (RN) de acordo com a faixa etária materna.

Estudo retrospectivo, documental, quantitativo e analítico desenvolvido com neonatos admitidos na UTI neonatal de um hospital em Fortaleza. A amostra: 770 prontuários de pacientes, sendo a faixa etária com maior número de nascidos entre 22 e 24 anos (52,4\%); 51,4\% das mães realizaram de 1 a 6 consultas pré-natais; $40,8 \%$ dos recém-nascidos tinham baixo peso; $41,6 \%$ são pré-termo tardio; $72 \%$ dos partos foram cesáreos; independente da faixa etária materna, o índice de Apgar do primeiro e quinto minuto foram 8 e 9, respectivamente; as intercorrências mais frequentes são síndrome do desconforto respiratório $(65,6 \%)$, prematuridade $(48,8 \%)$, hipoglicemia $(7,1 \%)$ e icterícia $(2,6 \%)$; a manobra de reanimação mais executada na sala de parto foi ventilação balão e máscara (17,5\%). Os resultados mostraram que mães com idade menor que 16 anos e maior que 40 anos realizam um maior número de consultas pré-natal que mulheres em extremos de idade, sendo esse dado relevante estatisticamente $(p=0,000)$. A frequência de partos vaginais foi superior a de cesarianas na faixa etária materna de menor de 16 anos, sendo que a frequência de partos abdominais evoluiu em crescimento, apresentando-se mais elevada, em detrimento da frequência de partos vaginais, na faixa etária maior de 40 anos, sendo este predomínio estatisticamente significativo $(p=0,014)$.

Palavras-chave: Idade materna. Recém-nascido. Assistência pré-natal. Peso ao nascer. Parto obstétrico. 


\section{INTRODUÇÃO}

A gravidez é uma fase de mudanças na vida da mulher no âmbito biológico, social, somático e psicológico devendo-se, então, observar a importância da correlação entre idade materna e resultados perinatais (PACCININI, 2008). Assim, devem ser levados em consideração não apenas os fatores biológicos implicados, mas também a condição de vida e saúde da gestante e, com especial atenção, como foi realizada a assistência obstétrica no pré-natal e durante o parto (XIMENES, 2004).

Em todo o processo, estão envolvidos como fatores de risco associados aos resultados perinatais: idade materna, morbidades clínicas preexistentes, condições sociodemográficas e história reprodutiva anterior. Entre as faixas etárias consideradas as que oferecem maior risco estão a de adolescentes menores de 16 anos e a de mulheres acima dos 35 anos (RIBEIRO, 2014).

É considerada gravidez na adolescência quando ocorre antes dos 20 anos, sendo consideradas adolescentes precoces as com idade inferior aos 16 anos (SANTANA, 2010). Estudos apontam como controversas as complicações entre os resultados perinatais em adolescentes, pois podem ocorrer maiores complicações obstétricas nessa faixa etária devido a fatores biológicos, como também podem estar relacionados mais fortemente ao acesso ao serviço de saúde e pré-natal (AZEVEDO, 2002; COSTA, 2006).

Em relação às complicações obstétricas, as mais prevalentes nessa faixa etária podem incluir: parto pré-termo e baixo peso ao nascer, devido à imaturidade anátomo-fisiológica, préeclâmpsia, amniorrexe prematura, diabetes gestacional e sofrimento fetal agudo, além de anemia da gestante por ela estar em fase de crescimento e retardo do desenvolvimento uterino, ocasionando, como consequência, prejuízos para o bebê (AZEVEDO, 2002; COSTA, 2006).

Pode-se relacionar a idade materna mais jovem e resultado perinatal a uma condição social mais frágil e, em consequência disso, um acesso precário aos serviços de saúde, como um bom acompanhamento pré-natal, sendo este essencial para o acompanhamento da gestação, garantindo o mínimo de seis consultas com avaliação dos parâmetros vitais, acompanhando desde as curvas de peso à altura uterina (AZEVEDO, 2002; SANTANA, 2010; SANTOS, 2009; SOUZA, 2004). A própria adolescência corresponde a um período crítico na vida da mulher, pois é quando ocorrem mudanças físicas, psicológicas e culturais e, como consequência, uma procura, muitas vezes, ineficaz do cuidado prénatal e do manejo do recém-nascido (MARTÍNEZ, 2015). Um número considerável de mulheres, 
principalmente menores de 20 anos iniciam de forma tardia o pré-natal por considerarem a gestação indesejada (SANTANA, 2010).

É importante observar a redução da taxa de fecundidade total do Brasil nas últimas décadas, de 6,2 para média de 2,2 filhos (SOUZA, 2004). Entretanto, essa taxa continua elevada na adolescência, principalmente nas regiões mais pobres, o que evidencia não só prejuízo à saúde materna e fetal, bem como uma forma de perpetuar o ciclo de pobreza (SOUZA, 2004).

Em contrapartida, a gestação em mulheres acima dos 35 anos denomina-se tardia e aquelas com mais de 45 anos podem ser consideradas de idade materna muito avançada (SANTANA, 2010). Assim, na gestação de mulheres com idade avançada, existe um maior risco decorrente da senescência ovariana e a maior frequência de doenças crônicas, entre elas, a hipertensão arterial (SANTOS, 2009). Em mulheres acima de 45 anos esses agravos são ainda mais importantes (AZEVEDO, 2002).

Essa tendência de adiamento da maternidade vem ocorrendo como um fenômeno mundial nos últimos anos (ALDRIGHI, 2016; PARADA, 2009). Decorrente, principalmente, da maior inserção da mulher no mercado de trabalho, melhores oportunidades de educação, expansão do planejamento familiar e uso de contraceptivos (ALDRIGHI, 2016; PARADA, 2009).

Um estudo que avaliou os fatores de risco associados à prematuridade e baixo peso ao nascer recémnascidos das parturientes nos extremos da vida reprodutiva em maternidade privada no estado do Pará, constatou que em mães acima de 34 anos a ocorrência de menos de seis consultas no pré-natal e o índice de Apgar no quinto minuto menor que sete predizem maiores chances de prematuridade e baixo peso ao nascer (CHERMONT, 2021).

Sendo assim, a gestação tardia ocasiona maior ocorrência de baixo peso ao nascer, índice de Apgar menor que sete, recém-nascido pré-termo e anomalias cromossômicas (SASS, 2011). Estudos mostram que uma assistência adequada no pré-natal, parto e período pós-parto melhoram o prognóstico materno e perinatal aproximando a parturiente das gestantes com idade mais jovem sem intercorrências importantes (ALDRIGHI, 2016).

Um importante registro de informações nacional sobre nascidos vivos é o Sistema de Informação sobre nascidos vivos (SINASC). O principal instrumento utilizado é a declaração de nascido vivo (DNV) preenchido após o nascimento por um profissional treinado (CORREIO, 2016). Possui como objetivo melhorar a qualidade das informações sobre os nascidos vivos no Brasil (CRAVO, 2012). Permite não apenas quantificar o total de nascidos vivos, mas também coletar variáveis úteis para avaliar as 
condições de nascimento, como idade e grau de instrução da mãe, duração da gestação, quantidade de consultas do pré-natal, Índice de Apgar e tipo de parto, permitindo, assim, a avaliação de variáveis que podem influenciar nos resultados perinatais (SANTOS, 2017). Como consequência, o conhecimento obtido a partir das informações relacionadas com as características da mãe e do recémnascido constitui um grande valor para as avaliações epidemiológicas; além disso, permite um acompanhamento mais adequado da situação da mãe e de seu bebê e a obtenção de dados para a elaboração e o aperfeiçoamento das políticas públicas de saúde materno-infantil (CRAVO, 2012).

Diante disso, a idade materna é um fator que pode ser relacionado com o resultado do peso ao nascimento (COSTA, 2006). Este parâmetro é importante para avaliar a condição de saúde do recémnascido, existindo influências de origem biológica, social e ecológica. Destacando-se, assim, a relevância dessa avaliação, pois o peso ao nascimento pode estar relacionado com a morbimortalidade neonatal e infantil (COSTA, 2006; MINAGAWA, 2006).

O objetivo desse estudo foi pesquisar a relação do perfil e do estado de saúde pós-parto dos recémnascidos (RN) de acordo com a faixa etária materna, buscando dados que relacionem o aumento de complicações do parto e do puerpério que possam ter associação com a faixa etária materna, sobretudo quanto às implicações no peso ao nascer.

\section{MATERIAIS E MÉTODOS}

Estudo retrospectivo, documental, quantitativo e analítico que foi desenvolvido com neonatos admitidos na UTI neonatal do Hospital Geral de Fortaleza (HGF) de 2017 a 2018. Foram incluídos no estudo 770 pacientes. Os critérios de inclusão utilizados abrangem os pacientes de todas as faixas etárias, independente da idade gestacional e do tipo de parto. Além disso, a avaliação clínica e física do bebê pelo neonato é um critério de inclusão. Os critérios de exclusão são partos de natimortos e bebês que morreram antes da avaliação da neonatologia.

As faixas etárias maternas foram divididas conforme as categorias a seguir: menores que 16 anos, 16 a 18 anos, 19 a 21 anos, 22 a 34 anos, 35 a 40 anos e maiores que 40 anos. Além da faixa etária materna, foram coletadas as seguintes variáveis referentes à gestação, ao parto e ao RN: número de consultas pré-natais, tipo de parto, apresentação do RN, sexo do RN, idade gestacional, peso ao nascer, estatura, perímetro torácico, perímetro cefálico, Apgar do $1^{\circ}$ e do $5^{\circ}$ minuto, manobra de reanimação na sala de parto e diagnóstico de entrada na UTI neonatal. 
As classificações da idade gestacional foram pré-termo extremo $<28$ semanas, pré-termo precoce de 28 a 32 semanas e 6 dias, pré-termo tardio de 33 a 36 semanas e 6 dias, a termo de 37 a 42 semanas e pós-termo de $>42$ semanas. Já quanto ao peso ao nascer, considerou-se extremo baixo peso se $<1000$ g, muito baixo peso a partir de 1000 g até 1499 g, baixo peso de 1500 g até 2499 g, peso adequado de $2500 \mathrm{~g}$ até $3999 \mathrm{~g}$ e macrossomia fetal a partir de 4000g.

Para a análise de dados, utilizou-se teste qui-quadrado de Pearson, por meio do software SPSS v23, SPSS Inc.

\section{RESULTADOS}

A amostra desse estudo consiste em 770 prontuários de pacientes que estavam internados na UTI neonatal de um hospital de referência de Fortaleza, sendo 375 (48,7\%) do sexo feminino e 395 (51,3\%) do sexo masculino. Além disso, 767 prontuários continham dados sobre a idade materna, totalizando $27(3,5 \%)$ mães com faixa etária menor que 16 anos, 84 (11\%) entre 16 a 18 anos, 110 (14,3\%) entre 19 a 21 anos, 402 (52,4\%) entre 22 a 34 anos, 121 (15,8\%) entre 35 a 40 anos e 23 (3\%) maior que 40 anos. Quanto ao número de consultas pré-natal 11 (1,43\%) não realizaram, 396 (51,4\%) 1 a 6 consultas e $340(44,1 \%)$ mais que 6 consultas.

Quanto a variável peso ao nascer dos RN, 32 (4,2\%) são classificados como extremo baixo peso, $101(13,1 \%)$ muito baixo peso, $314(40,8 \%)$ baixo peso, $285(37 \%)$ peso adequado e 38 (4,9\%) macrossomia. Já em relação à idade gestacional, foi possível identificar esse dado em 766 prontuários, sendo 44 (5,7\%) pré-termos extremos, 162 (21,1\%) pré-termos precoces, 319 (41,6\%) pré-termos tardios, 236 (20,8\%) a termo e 5 (0,7\%) pós-termos.

Avaliando primeiramente a faixa etária materna menor que 16 anos, foram observados 10 (37\%) partos cesáreos e 17 (63\%) partos vaginais. Quanto à apresentação ao nascimento, 23 (85,2\%) foram cefálicos e 4 (14,8\%) pélvicos. Já a mediana dos prontuários que continham a informação da idade gestacional foi 34 semanas (CL 34 a 37); a do peso do RN ao nascer foi 2040g (CL 1700 a 2300); a da estatura foi 43cm (CL 42 a 46); a do perímetro cefálico foi 31cm (CL 29,5 a 33); a do perímetro torácico foi 30cm (CL 28 a34); a do APGAR do $1^{\circ}$ minuto foi 8 (CL 8 a 9); a do APGAR do $5^{\circ}$ minuto foi 9 (CL 9 a 10). Em relação ao número de consultas pré-natal, 18 (66,7\%) mães realizaram de 1 a 6 consultas e 8 $(29,6 \%)$ mais de 6 consultas.

Na faixa etária materna de 16 a 18 anos, 46 (54,8\%) realizaram partos cesáreos e 38 (45,2\%) partos vaginais. Sobre a apresentação ao nascimento, 72 (85,7\%) foram cefálicos e 12 (14,3\%) pélvicos. Já a 
mediana dos prontuários que continham a informação da idade gestacional foi 34 semanas (CL 34 a 36); a do peso do RN ao nascer foi 2332g (CL 2070 a 2470); a da estatura foi 44cm (CL 43 a 46); a do perímetro cefálico foi 32cm (CL 31 a 33,5); a do perímetro torácico foi 29cm (CL 28 a 30); a do APGAR do $1^{\circ}$ minuto foi 8 (CL 8 a 9); a do APGAR do $5^{\circ}$ minuto foi 9 (CL 9 a 10). Quanto ao número de consultas pré-natal, $58(69 \%)$ realizaram 1 a 6 consultas, $23(27,4 \%)$ mais de 6 consultas e $2(2,4 \%)$ mães não realizaram pré-natal.

Em relação a faixa etária materna de 19 a 21 anos, foram observados 80 (72,7\%) partos cesáreos e 30 (27,3\%) partos vaginais. Quanto à apresentação ao nascimento, 91 (82,7\%) foram cefálicos e 18 $(16,4 \%)$ pélvicos. Já a mediana dos prontuários que continham a informação da idade gestacional foi 35 semanas (CL 34 a 36); a do peso do RN ao nascer foi 2400g (CL 2152 a 2592); a da estatura foi $45 \mathrm{~cm}$ (CL 44 a 47); a do perímetro cefálico foi 32cm (CL 32 a 33); a do perímetro torácico foi 30cm (CL 29 a31); a do APGAR do $1^{\circ}$ minuto foi 8 (CL 8 a 9); a do APGAR do $5^{\circ}$ minuto foi 9 (CL 9 a 10). Quanto ao número de consultas pré-natal, $53(48,2 \%)$ realizaram 1 a 6 consultas, 53 (48,2\%) mais de 6 consultas e $1(0,9 \%)$ mães não realizaram pré-natal.

Na faixa etária materna de 22 a 34 anos, 306 (76,1\%) efetuaram partos cesáreos e 96 (23,9\%) partos vaginais. No que concerne à apresentação ao nascimento, $326(81,1 \%)$ foram cefálicos, 70 (17,4\%) pélvicos e $2(0,5 \%)$ transversos. No que diz respeito à mediana dos prontuários que continham a informação da idade gestacional foi 34 semanas (CL 34 a 35); a do peso do RN ao nascer foi $2400 \mathrm{~g}$ (CL 2378 a 2500); a da estatura foi $44 \mathrm{~cm}$ (CL 44 a 45); a do perímetro cefálico foi $32 \mathrm{~cm}$ (CL 32 a 33); a do perímetro torácico foi $30 \mathrm{~cm}$ (CL 30 a 31); a do APGAR do $1^{\circ}$ minuto foi 8 (CL 8 a 9); a do APGAR do $5^{\circ}$ minuto foi 9 (CL 9 a 10). Quanto ao número de consultas pré-natal, 207 (51,5\%) realizaram 1 a 6 consultas, $178(44,3 \%)$ mais de 6 consultas e 7 (1,7\%) mães não realizaram pré-natal.

Já quanto aos dados referentes à faixa etária materna de 35 a 40 anos, foram observados 91 (75,2\%) partos cesáreos e $30(24,8 \%)$ partos vaginais. Em relação à apresentação ao nascimento, 98 (81\%) foram cefálicos, 20 (16,5\%) pélvicos e $1(0,8 \%)$ transversos. Além disso, a mediana dos prontuários que apresentavam informação sobre idade gestacional foi 35 semanas (CL 35 a 37); a do peso do RN ao nascer foi 2388g (CL 2110 a 2714); a da estatura foi 44,5cm (CL 43 a 46); a do perímetro cefálico foi 32,3cm (CL 31,5 a 33); a do perímetro torácico foi 31cm ( $C L$ 30,5 a 33); a do APGAR do $1^{\circ}$ minuto foi 8 (CL 8 a 9); a do APGAR do $5^{\circ}$ minuto foi 9 (CL 9 a 10). No tocante ao número de consultas pré-natal, 50 $(41,3 \%)$ realizaram 1 a 6 consultas, $67(55,4 \%)$ mais de 6 consultas e $1(0,8 \%)$ mães não realizaram prénatal. 
No que concerne à faixa etária materna maior que 40 anos, foram verificados 20 (87\%) partos cesáreos e 3 (13\%) partos vaginais. Quanto à apresentação ao nascimento, 16 (69,6\%) foram cefálicos, $6(26,1 \%)$ pélvicos e $1(4,3 \%)$ transversos. Além do mais, a mediana dos prontuários que apresentavam informação sobre idade gestacional foi 34 semanas ( $C L 33$ a 38); a do peso do RN ao nascer foi 2326g (CL 1710 a 2788); a da estatura foi 44cm (CL 42a 48); a do perímetro cefálico foi 32cm ( $C L 30$ a 34,5); a do perímetro torácico foi 30cm (CL 29,5 a 32); a do APGAR do $1^{\circ}$ minuto foi 8 (CL 8 a 9); a do APGAR do $5^{\circ}$ minuto foi 9 (CL 9 a 10). Por fim, o número de consultas pré-natal, 10 $(43,5 \%)$ realizaram 1 a 6 consultas e $13(56,5 \%)$ mais de 6 consultas.

No que diz respeito ao diagnóstico admissional dos RN na UTI, os mais prevalentes foram 505 (65,6\%) casos de síndrome do desconforto respiratório (SDR), 376 (48,8\%) de prematuridade, 55 (7,1\%) de hipoglicemia e 20 (2,6\%) de icterícia.

Analisando a variável manobras de reanimação na sala de parto, 256 (33,2\%) necessitaram de pelo menos uma manobra e 411 (53,4\%) não realizado. Das manobras verificadas nos prontuários, foram realizados 135 (17,5\%) ventilações balão e máscara, 71 (9,2\%) ventilações manuais em T, 69 (9\%) intubações, 20 (2,6\%) CPAP, 17 (2,2\%) VPP, 15 (1,9\%) ventilações VMM e COT, 7 (0,9\%) ventilações B e COT, 5 (0,6\%) massagens cardíacas, 4 (0,5\%) ventilações baby puff, $3(0,4 \%)$ medicamentos e $6(0,8 \%)$ não foram especificadas o tipo de ventilação. Por fim, $1(0,1 \%)$ paciente precisou de todas as manobras supracitadas.

$\mathrm{Na}$ análise de associação entre a faixa etária materna e as covariáveis em estudo, verificou-se que as variáveis tipo de parto $(p=0,000)$ e número de consultas pré-natal $(p=0,014)$ apresentaram significância estatística.

\section{DISCUSSÃO}

No que se refere a porcentagem de nascimentos em associação com faixas etárias maternas, o trabalho realizado em Liverpool avaliando 9506 prontuários, observou-se que 5,6\% das mães eram adolescentes (<20 anos), 92\% estavam na faixa de 20-40 anos e 2,4\% eram >40 anos (DELPISHEH, 2008), em consonância, estudo Maranhense executado com 2.196 pacientes, foi verificada frequência de $25 \%$ dos partos em adolescentes, $69 \%$ em adultas e $6 \%$ de mulheres em idade avançada (SANTOS, 2009). Ademais, em revisão de literatura, constatou-se que Santana (2010), ratificou as informações acima e que os resultados obtidos no presente estudo corroboram com o encontrado na literatura, ou seja, nascem menos crianças nos extremos de idade materna (SANTANA, 2010). 
Entretanto, na análise do perfil de recém-nascido de baixo peso (RNBP) registrados no SINAN do estado do Pernambuco de 2017, totalizando 10.498 registros, foi observado que faixa etária de 45 a 49 anos obteve maior percentual (13,53\%), seguida das adolescentes precoces de 10 a 14 anos (13,39\%) (SILVA, SILVA, 2021), dessa forma, embora seja menor o nascimento de crianças nos extremos de idade materna é justamente nesses extremos a maior prevalência de recém-nascidos com baixo peso (RNBP).

A assistência ao pré-natal é considerada um dos principais parâmetros de prognóstico ao nascimento, possibilitando o diagnóstico e tratamento de diversas intercorrências durante a gravidez e a diminuição dos possíveis fatores e comportamentos de risco capazes de serem corrigidos (ANTONIO, 2009; ANJOS, 2016; VILAS BOAS, 2016). Santos (2009) e Anjos (2016) afirmam que gestantes adolescentes frequentam menos e mais tarde as consultas no período pré-natal, e mulheres com idade maior ou igual a 40 anos, em sua maioria, realizam 7 ou mais consultas (SANTOS, 2009; ANJOS, 2016). Santana (2010) comprovou, em estudo no Tocantins, que mulheres em idade avançada foram as que em maior porcentagem não fizeram nenhuma consulta, e que as adolescentes frequentaram mais os pré-natais (SANTANA, 2010). É importante destacar que se encontrou no presente estudo que as faixas de idade que mais realizavam pré-natal foram as 18 a 21 anos, 22 a 34 anos e 35 a 40 anos, com $p=0,014$. Ao contrário do estudo de Terra et al que estudando o perfil dos recém-nascidos e das puérperas com idade até 19 anos e superior a 35 anos, cadastradas no "Programa Prá Nenê", Pelotas, evidenciaram que as adolescentes realizaram menor número de consultas de pré-natal $(43,8 \%)$ e iniciaram mais tardiamente o acompanhamento quando comparadas com mulheres maduras (TERRA, 2018).

Ademais, sobre o peso ao nascimento, literaturas apontam que a prematuridade e desnutrição intrauterina são fatores de risco que contribuem para um baixo peso ao nascer (SASS, 2011; NILSON, 2015). Análises estatísticas brasileiras constataram que 17,5\% das crianças pré-termo apresenta peso ao nascer $<1500$ g, necessitando de auxílio na transição cardiorrespiratória para adequar-se à vida extrauterina (COSTA, 2015). Destaca-se que a falha na adaptação dessa transição é responsável por elevar a taxa de mortalidade perinatal no Brasil, atingindo uma porcentagem de até 70\% (COSTA, 2015). É ainda, relevante lembrar que, os recém-nascidos de puérperas adolescentes tiveram um maior baixo peso ao nascer $(43,9 \%)$, enquanto as mães maduras tiveram filhos com maior peso ao nascer (37,6\%) conforme o estudo de Pelotas (TERRA, 2018). 
Em continuidade, vale ressaltar que pesquisa realizada no Departamento de Pediatria da Faculdade de Ciências Médicas de Campinas demonstrou que não há correlação entre tempo gestacional e peso inadequado ao nascimento (ANTONIO, 2009). Comorbidades metabólicas na gestação, como diabetes, são responsáveis pela ocorrência de nascimentos de crianças acima do peso $>4000 \mathrm{~g}$ (OLIVEIRA, 2018). Apesar desse estudo atual não ter como propósito analisar os fatores maternos que levam ao nascimento de crianças com peso inadequado, encontrou-se uma prevalência de baixo peso ao nascer, que pode ser justificada pela amostra ser constituída por paciente de UTI neonatal, o que mostra, de acordo com Melo, 2013, a necessidade de políticas públicas voltadas para reduzir a prematuridade e o baixo peso do RN, diminuindo, assim, a morbimortalidade infantil (MELO, 2013).

A idade gestacional pesquisada em Tocantins obteve significância estatística $(p<0,05)$ em determinar que adolescentes apresentam mais partos pré-termo que o esperado; mulheres de 20-34 anos, maior quantidade de partos à termo, e mulheres de idade avançada, gestações mais prolongadas (SANTANA, 2010). Corroborando com o resultado acima, a ocorrência de partos prematuros no grupo de mulheres mais jovens está em harmonia com diversos relatos bibliográficos. (SANTOS, 2009). Contudo, Rocha (2006) afirmou que não houve diferença significativa da associação entre idade materna e tempo de gestação (ROCHA, 2006). Já no atual estudo, obteve-se uma maior proporção de nascimentos prétermo, fato este que pode ser justificado pela amostra ser constituída por recém-nascidos internados em UTI neonatal.

Em se tratando de tipo de parto, o presente estudo comprovou que a grande maioria das mães realizaram partos cesáreos $(p=0,000)$. Já Santana $(2010)$ contatou relação significativa $(p<0,05)$ entre essa variável e a idade da mãe, afirmando que mulheres mais jovens (10-19 anos) realizam mais partos vaginais, as de mais idade (> 35 anos), mais partos cesáreos e no grupo 20-34 anos, predominam partos cesáreos (SANTANA, 2010). Estudos produzidos na Faculdade de Medicina de São Paulo e na Universidade Estadual de Maringá revalidam que pacientes > 35 anos apresentam maior probabilidade de ter filhos por partos operatórios, devido a ocorrência de anormalidades clínicas, como desnutrição, diabetes, hipertensão, anemia ferropriva materna, sangramento vaginal e infecção do trato urinário (NOMURA, 2004; ROCHA, 2006; GRAVENA, 2013). Além disso, Santos (2009) declara que mulheres com melhores condições socioeconômicas, maior escolaridade e que compareceram a mais consultas pré-natal optam por realizar partos cesáreos, determinando que não são apenas os fatores clínico que define o tipo de parto (SANTOS, 2009). Segundo Terra, 2018, a frequência de partos vaginais diminuiu com o aumento da idade (38,2\%), em Pelotas (TERRA, 2018). 
Na variável índice de Apgar, que é o parâmetro mais relevante para mensurar o prognóstico do nascimento, as literaturas consultadas observam que os extremos de idade materna apresentam alto risco de asfixia moderada e grave, representando valores de Apgar menores que sete (GOLDENBERG, 2005; SASS, 2011; GRAVENA, 2013). Em estudo realizado em Minas Gerais, constatou-se que mães na faixa de idade 10-14; 15-19 e acima de 20 anos (adultas) apresentam 6,0\%; 3,3\% e 2,9\%, respectivamente, de $\mathrm{RN}$ com índice de Apgar no primeiro e quinto minuto abaixo de sete (GOLDENBERG, 2005). Assim, reforçando as ideias acima, Silva (2019) declara que a faixa etária de 21 a 30 anos apresentou melhor Apgar, aproximadamente $38,42 \%$ obtiveram valor entre 08 e 10 , reduzindo o risco de asfixia (SILVA, 2019). No entanto, no presente estudo, verificou-se que as medianas do Apgar no primeiro e quinto minuto, independente da faixa etária materna, obtiveram valor 8 e 9, respectivamente, indo de encontro as bibliografias supracitadas.

No que concerne a idade materna, segundo pesquisas há divergências sobre o impacto dessa variável como fator de risco para desfechos desfavoráveis no período perinatal (JIMENEZ, 2001; SANTOS, 2009). Um trabalho brasileiro constatou que adolescentes e mulheres >35 anos apresentam, em geral, maior risco de complicações maternas e perinatais (SANTOS, 2009). Além disso, outros estudos associam idade materna extrema com o baixo peso ao nascer e a prematuridade (XIMENES, 2004; SUZUKI, 2007; SANTOS, 2009; SASS, 2011).

Abordando a faixa etária de adolescentes, a gravidez nessa fase é considerada um problema de saúde pública, devendo-se a dificuldades socioculturais e biológicas, assim surgiu-se a hipótese de que os partos pré-termos ocorriam devido a uma imaturidade orgânica dessas mulheres (XIMENES, 2004; SANTANA, 2010; COSTA, 2011; NILSON 2015). Diante disso, essa faixa etária requer uma atenção especial, já que existe uma maior probabilidade alterações na evolução da gestação e no crescimento fetal (AZEVEDO, 2002; ROCHA, 2006; GRAVENA 2013).

Segundo Silva (2020), outro aspecto importante relacionado a idade materna é a amamentação; pois o tempo dedicado ao aleitamento materno é menor quando se trata de mães mais novas. A gravidez precoce traz vários conflitos que interferem na continuidade do aleitamento: sensação de culpa pela gravidez precoce, problemas com o pai, mudanças inesperadas com o corpo, dentre outros. Portanto, é possível ocorrer um prejuízo no estado nutricional e desenvolvimento emocional da criança.

Em relação a mães com idade mais avançada (> 35 anos), a literatura aponta um maior risco de complicações obstétricas e fetais. Isso se deve em parte a senescência ovariana e o aumento de doenças crônicas, como diabetes mellitus e hipertensão arterial (AZEVEDO, 2002). Dessa forma, 
observou-se maior risco de mortalidade perinatal, baixa vitalidade do recém-nascido, baixo peso ao nascer, parto pré-termo e fetos pequenos para idade gestacional (GRAVENA, 2013).

Conforme Costa (2015) as intercorrências neonatais mais prevalentes observadas são icterícia, distúrbio respiratório e hipoglicemia, com respectivamente 20,7\%; 6,4\%; 1,3\% (COSTA, 2015). Em consonância, a pesquisa atual evidenciou que essas intercorrências supracitadas também foram as mais frequentes, juntamente com a prematuridade. Nesse contexto, pesquisa executada no Peru mostrou que mães com mais de 35 anos, multiparidade e a realização de 4 a 6 consultas prénatais possuem influência no desfecho de hipoglicemia neonatal (QUISPE, 2015). Além disso, o grau de prematuridade foi associado a alta incidência e gravidade de SDR, devido a importante interferência da idade gestacional na maturidade do pulmão fetal (DO NASCIMENTO JUNIOR, 2014). Ademais, mães de neonatos nascidos com icterícia, em geral, estão situadas na faixa etária de 16 a 20 anos (GALINDEZ-GONZALES, 2017).

Observando uma coorte na literatura, realizada com 5845 RN, foi verificado a necessidade de reanimação em 15,7\% (BOUZADA, 2018). Já no vigente estudo 33,2\% dos pacientes utilizaram algum recurso de reanimação. A Sociedade Brasileira de Pediatria, por meio do Programa de Reanimação Neonatal, analisando as manobras de reanimação em 1054prematuros, 14\% utilizaram ventilação balão e máscara, 3\% intubação e 0,9\% massagem cardíaca (CARVALHO, 2011). Concordando com Carvalho (2011) a atual pesquisa afirma que a manobra mais prevalente foi ventilação balão e máscara.

Interessante ressaltar, ainda, a explanação de Viellas (2021) sobre a ausência de políticas públicas voltadas para mulheres com mais de 34 anos. O que já se observa com frequência são os movimentos especializados para mães adolescentes. Entretanto, com o aumento do número de gestações mais tardias, a atenção obstétrica deve ser voltada também para elaborar diretrizes gerais e manuais do Ministério da Saúde (MS), visando uma melhor assistência a esse novo perfil de binômio mãe-bebê que vem crescendo (VIELLAS, 2021).

\section{CONSIDERAÇÕES FINAIS}

Conclui-se que nascem menos crianças nos extremos de idade, mães com idade $<16$ ano e $>40$ anos, que mães de $>40$ anos realizam um maior número de consultas pré-natal, sendo esse último dado relevante estatisticamente $(p=0,000)$. Ademais as intercorrências mais prevalentes foram síndrome do desconforto respiratório, prematuridade, hipoglicemia e icterícia. A frequência de partos vaginais 
foi inferior à de cesarianas nas faixas etárias maternas <16 anos, sendo este predomínio estatisticamente significativo $(p=0,014)$.

Nota-se que a assistência ao pré-natal é de fundamental importância para garantir a saúde materna e fetal, sendo considerada um dos principais parâmetros de prognóstico ao nascimento. Isso possibilita o diagnóstico e tratamento de diversas intercorrências durante a gravidez, diminuindo possíveis fatores e comportamentos de risco. Diante disso, percebe-se a necessidade de um maior engajamento dos profissionais na realização de educação em saúde durante as consultas. Assim como, uma ampliação de políticas públicas voltadas para o estímulo à adesão ao pré-natal, o que pode reduzir a morbimortalidade infantil.

Considerando as limitações deste estudo, sugere-se que o alto predomínio de RN de baixo peso ao nascer e nascimentos pré-termo deve-se, em grande parte, a amostra ter sido constituída por pacientes de UTI neonatal. Desse modo, recomenda-se a realização de mais estudos que incluam uma população mais ampliada na amostra estudada. 


\section{REFERÊNCIAS}

ALDRIGHI, J. D. et al. As experiências das mulheres na gestação em idade materna avançada: revisão integrativa. Revista da Escola de Enfermagem USP, v. 50, n. 3, p. 512-521, 2016.

ALMEIDA, A. C. DE et al. Fatores de risco maternos para prematuridade em uma maternidade pública de Imperatriz-MA. Rev. Gaúcha Enferm., Porto Alegre, v. 33, n. 2, p. 86-94, June 2012.

ANJOS, J. C. DOS; BOING, A. F.. Diferenças regionais e fatores associados ao número de consultas de pré-natal no Brasil: análise do Sistema de Informações sobre Nascidos Vivos em 2013. Rev. Bras. Epidemiol., São Paulo, v. 19, n. 4, p. 835-850, dez. 2016.

ANTONIO, M. Â. R. G. M. et al. Fatores associados ao peso insuficiente ao nascimento. Rev. Assoc. Med. Bras., São Paulo, v. 55, n. 2, p. 153-157, set 2009.

AZEVEDO, G. D. DE et al. Efeito da Idade Materna sobre os Resultados Perinatais. Rev. Bras. Ginecol. Obstet., Rio de Janeiro, v. 24, n. 3, p. 181-185, mar 2002.

BOAS, V., \& COSTA, I. M. Incidência do baixo peso ao nascer em Santo Antônio de Jesus-Bahia: resultados preliminares de uma coorte prospectiva. 2019. 46f. Trabalho de Conclusão de Curso Universidade Federal do Recôncavo da Bahia, Santo Antônio de Jesus, 2016.

BOUZADA, M. C. F. et al. Resposta aos procedimentos de reanimação neonatal no quinto minuto de vida em recém-nascidos Apgar 3 no primeiro minuto. Rev Med Minas Gerais, v. 28, n. Supl 6, 2018. DOI: http://www.dx.doi.org/10.5935/2238-3182.20180100

CARVALHO, H. M. B. O recém-nascido pré-termo tardio: os desafios. Rev Saúde Criança Adolesc, v. 3, n. 1, p. 14-8, 2011.

CHERMONT A. G., SILVA E. F. A. da, VIEIRA C. C., FILHO L. E. C. de S., MATSUMURA E. S. de S., \& CUNHA K. da C. (2020). Fatores de risco associados à prematuridade e baixo peso ao nascer nos extremos da vida reprodutiva em uma maternidade privada. Revista Eletrônica Acervo Saúde, (39), e2110. https://doi.org/10.25248/reas.e2110.2020. Acesso: 14 de ago 2021.

CORREIO, R. A. D. S.; CORREIO, L. F.; CORREIO, M. A. B. Perfil epidemiológico dos nascidos vivos no município de Chapecó-SC. Revista Eletrônica de Comunicação, Informação e Inovação em Saúde, v. 10, n. 2, p. 1-16, 2016.

COSTA, B. C. et al. Análise comparativa de complicações do recém-nascido prematuro tardio em relação ao recém-nascido a termo. Boletim Científico de Pediatria-Vol, v. 4, n. 2, 2015.

COSTA, T. DE J. M. DA; HEILBORN, M. L. Gravidez na adolescência e fatores de risco entre filhos de mulheres nas faixas etárias de 10 a 14 e 15 a 19 anos em juiz de fora. Revista de Atenção Primária a Saúde, v. 9, n. 1, p. 29-38, 2006.

CRAVO, E. O.; OLIVEIRA, J. V. R. DE. Perfil Epidemiológico Dos Nascidos Vivos No Município De Aracaju - Sergipe, Brasil. Ideias \& Inovação, v. 1, n. 1, p. 9-17, 2012.

DA SILVA, T. B. et al. Apgar Score related to Maternal/Obstetrical and Neonatal Factors. Revista Prevenção de Infecção e Saúde, v. 5, n. 8389, p. 1-11, jun 2019. 
DELPISHEH, A. et al. Pregnancy late in life: a hospital-based study of birth outcomes. Journal of women's health, Richmond, v. 17, n. 6, p. 965-970, jul 2008.

DO NASCIMENTO JÚNIOR, F. J. M. et al. A síndrome do desconforto respiratório do recém-nascido: fisiopatologia e desafios assistenciais. Caderno de Graduação-Ciências Biológicas e da Saúde-UNITALAGOAS, Maceió, v. 2, n. 2, p. 189-198, nov 2014.

GALINDEZ-GONZALEZ, A. L. et al. Factores predisponentes para ictericia neonatal en los pacientes egresados de la UCI neonatal, Hospital Infantil los Ángeles de Pasto. Univ. Salud, Pasto, v. 19, n. 3, p. 352-358, dez 2017.

GOLDENBERG, P.; FIGUEIREDO, M. C. T.. Gravidez na adolescência, pré-natal e resultados perinatais em Montes Claros, Minas Gerais, Brasil Adolescent pregnancy, prenatal care, and perinatal outcomes in Montes Claros. Cad. Saúde Pública, Rio de Janeiro, v. 21, n. 4, p. 1077-1086, ago 2005.

GRAVENA, A. A. F. et al. Idade materna e fatores associados a resultados perinatais. Acta paul. enferm., São Paulo, v. 26, n. 2, p. 130-135, abr 2013.

JIMÉNEZ, M. A.; MARTíN, A. R.; GARCÍA, J. R. Comparing the biological and psychosocial risks of pregnancy between groups of adolescents and adults. European journal of epidemiology, Dordrecht, v. 16, n. 6, p. 527, jun 2000.

MARTÍNEZ, H. T. et al. Obstetric profile of pregnant adolescents in a public hospital: risk at beginning of labor, at delivery, postpartum, and in puerperium. Revista Latino Americana de Enfermagem, v. 23, n. 5, p. 829-836, 2015.

MELO, E. C. et al. Fatores relacionados ao parto cesáreo, baixa cobertura de pré-natal e baixo peso ao nascer. Revista de Enfermagem e Atenção à Saúde, Uberaba, v. 2, n. 01, jul 2013.

MINAGAWA, A.T. et al. Baixo peso ao nascer e condições maternas no pré-natal. Revista da escola de enfermagem da USP, São Paulo, v. 40, n. 4, p. 548-554, 2006.

NILSON, L. G. et al. Proporção de baixo peso ao nascer no Brasil e regiões brasileiras, segundo variáveis sócio-demográficas. Revista de Saúde Pública de Santa Catarina, Florianópolis, v. 8, n. 1, p. 69-82, janabr 2015.

NOMURA, R. M. Y.; ALVES, E. A.; ZUGAIB, M.. Complicações maternas associadas ao tipo de parto em hospital universitário. Rev. Saúde Pública, São Paulo, v. 38, n. 1, p. 9-15, fev 2004.

OLIVEIRA, A. C. M. DE et al. Estado nutricional materno e sua associação com o peso ao nascer em gestações de alto risco. Ciênc. saúde coletiva, Rio de Janeiro , v. 23, n. 7, p. 2373-2382, jul 2018.

PACCININI, C. A. et al. Gestação e a constituição da maternidade. Psicologia em Estudo, v. 13, n. 1, p. 63-72, 2008.

PARADA, C. M. G. DE L.; TONETE, V. L. P. Experiência da gravidez após os 35 anos de mulheres com baixa renda. Escola Anna Nery Revista de Enfermagem, v. 13, n. 2, p.385-392, 2009.

QUISPE, G. M. C. Factores asociados a la hipoglucemia neonatal en el Hospital Regional Docente Materno Infantil el Carmen, 2013. Ágora Revista Científica, v. 2, n. 2, p. 196-203, 2015. 
RIBEIRO, F. D. et al. Extremos de idade materna e mortalidade infantil: análise entre 2000 e 2009. Revista Paulista de Pediatria, v. 32, n. 4, p. 326-332, 2014.

ROCHA, R. C. L. DA et al. Prematuridade e baixo peso entre recém-nascidos de adolescentes primíparas. Rev. Bras. Ginecol. Obstet., Rio de Janeiro, v. 28, n. 9, p. 530-535, set 2006.

SANTANA, F. G. et al. Relação entre a idade materna e condições perinatais no município de Augustinópolis-TO. Revista de Pesquisa em Saúde, São Luís, v. 11, n. 3, p. 35-40, set-dez 2010.

SANTOS, G. H. N. DOS et al. Impacto da idade materna sobre os resultados perinatais e via de parto. Rev. Bras. Ginecol. Obstet., Rio de Janeiro, v. 31, n. 7, p. 326-334, jul 2009.

SASS, A. et al. Resultados perinatais nos extremos da vida reprodutiva e fatores associados ao baixo peso ao nascer. Rev. Gaúcha Enferm., Porto Alegre, v. 32, n. 2, p. 362-368, jun 2011.

SILVA, A. C. L. et al. Fatores atuais que interferem na amamentação. Anais do EVINCI - UniBrasil, Curitiba, v.6, n.1, p. 220-220, out. 2020

SILVA, R. E.; SILVA, M. G. P. Perfil de recém-nascidos de baixo peso ao nascer no Estado de Pernambuco. Rev. Enfer. Digit. Cuid. e Promoção da Saúde. v. 1, n. 6, 2021. DOI: http://www.dx.doi.org/10.5935/2446-5682.20210011

SOUZA, K. E. P. DE; CONCEIÇÃO, M. Maternidade na adolescência e nascidos vivos: análise temporal ( 2000 a 2004 ) segundo o SINASC de um município do Nordeste do Brasil. Adolescência \& Saúde, v. 5, n. 1, p. 14-22, 2004.

SUZUKI, C. M. et al. Análise comparativa da freqüência de prematuridade e baixo peso entre filhos de mães adolescentes e adultas. Rev. bras. crescimento desenvolv. hum., São Paulo, v. 17, n. 3, p. 95-103, dez. 2007.

TERRA, A. P. et al. Idade materna e condições perinatais, entre nascimentos de risco de 2008 a 2013. Rev Enferm UFPI. 2018 Jan-Mar;8(1):30-7

VIELLAS, E. F. et al. Assistência ao parto de adolescentes e mulheres em idade materna avançada em maternidades vinculadas à Rede Cegonha. Rev Ciência e Saúde Coletiva, 26(3):847-858, 2021.

XIMENES, F. M. A.; OLIVEIRA, M. C. R. DE. A Influência da Idade Materna Sobre as Condições Perinatais. Revista Brasileira em Promoção da Saúde, v. 17, n. 2, p. 56-60, 2004. 


\section{Capítulo 6}

\section{d.)}

\section{AVALIAÇÃO DA PREVALÊNCIA DA DOENÇA PERIODONTAL EM PACIENTES COM DOENÇA RENAL CRÔNICA SOB TRATAMENTO DE HEMODIÁLISE}

Jairton Costa Filho

Thaiane Caroline Nascimento Costa
UNIVERSIDADE CEUMA

UNIVERSIDADE CEUMA 
Resumo: Estudos recentes apontam a doença periodontal (dp) como fator de risco para a doença renal crônica (drc). Objetivo: avaliar a condição periodontal em pacientes sob hemodiálise, no centro de nefrologia do maranhão - cenefron. Metodologia: trata-se de um estudo transversal, realizado de agosto a novembro de 2015, com avaliação de 180 pacientes, utilizando-se um questionário. A avaliação da condição periodontal foi realizada utilizando a classificação da doença periodontal segundo a aap 1999. Para análise estatística os dados foram tabulados no programa stata 12.0, o teste exato de qui-quadrado, foi utilizado para verificar as associações estatísticas significantes de $95 \%$ $(p<0,05)$. Resultados: os resultados encontrados apontam que apenas $15,2 \%$ possuem uma condição periodontal saudável, e 84,8 \% apresentam alterações periodontais. Conclusões: numa porcentagem bastante significativa dos pacientes as manifestações das doenças periodontais estiveram presentes, mesmo naqueles com uma boa frequência de escovação dentária. A doença periodontal com maior frequência foi periodontite crônica leve localizada em pacientes com o tempo de hemodiálise entre 1 e 2 anos, ressaltando a necessidade de acompanhamento odontológico periódico e manutenção de hábitos adequados relacionados à saúde bucal.

Palavras-chave: Diálise renal, insuficiência renal crônica, doenças periodontais, saúde bucal. 


\section{INTRODUÇÃO}

No brasil os dados sobre a epidemiologia da doença renal crônica $(\mathrm{drc})$ se restringem aos pacientes sob terapia renal substitutiva. São alarmantes os números sobre a prevalência de pacientes em tratamento de hemodiálise. Essa situação mundial da drc assume grande importância no que se refere à doença periodontal, por se tratar de uma doença de caráter infeccioso multifatorial, associada como fator de risco para algumas doenças sistêmicas ${ }^{1}$.

Esse número vem aumentando gradualmente ao longo dos anos, de 42.695, em 2000, para 92.091, em 2010. Mais da metade desses pacientes se encontrava na região sudeste. A taxa de prevalência do tratamento dialítico em 2010 foi de 483 pacientes por milhão da população (pmp), variando por região entre 265 pacientes por milhão da população (pmp) na região norte a 591 pacientes por milhão da população (pmp) na sudeste. O número estimado de pacientes que iniciaram tratamento em 2010 no brasil foi de 18.972, correspondendo a uma taxa de incidência de 99,5 pacientes pmp².

A drc é definida por anormalidades estruturais ou funcionais do rim, com ou sem diminuição da taxa de função glomerular (tfg), evidenciada por anormalidades histopatológicas ou de marcadores de lesão renal, incluindo alterações sanguíneas ou urinárias, ou ainda de exames de imagem; tfg <60 $\mathrm{ml} / \mathrm{min} / 1,73 \mathrm{~m} 2$ por um período igual ou superior a três meses com ou sem lesão renal ${ }^{3,4}$.

A drc caracteriza-se por uma perda lenta, progressiva e irreversível da função dos néfrons, desde a filtração glomerular, o equilíbrio da volemia, o controle da pressão arterial e dos eletrólitos, até as capacidades endócrinas renais, desencadeando uma série de fenômenos humorais e celulares, resultando no declínio progressivo da taxa de filtração glomerular, até a perda da função renal ou doença renal crônica terminal (drct) 5,6,7.

Tais mudanças sistêmicas podem refletir no meio bucal, levando a alterações na composição salivar, com aumento dos níveis de uréia, potássio, fosfato e aumento dos níveis de ca e mg7; no nível do fluxo salivar, com diminuição do mesmo; no ph salivar, que pode ser mais alcalino; na capacidade-tampão, com aumento da mesma e elevada formação de cálculo dentário ${ }^{8}$.

Além disso, a falta de cuidados com a higiene bucal pode afetar a saúde bucal destes pacientes, resultando em mais cáries, doenças periodontais e lesões bucais. Não há consenso quanto à predisposição destes pacientes à cárie dentária. Em pesquisas realizadas foram observados que não houve mudança quanto à ocorrência de cárie dentária. Em alguns estudos observaram-se que a experiência de cárie dentária foi elevada nos pacientes em diálise, enquanto que em outras pesquisas 
realizadas pacientes com doença renal crônica em diálise apresentaram menores índices de cárie dentária ${ }^{8}$.

Sabe-se ainda que a drc pode exibir variadas manifestações bucais como xerostomia, estomatite urêmica, alterações radiográficas dos ossos maxilares, formação de cálculo dentário decorrente do aumento da concentração de fosfato e cálcio sérico e outras menos frequentes ${ }^{8}$.

Com relação à presença de placa bacteriana, alguns estudos ${ }^{8}$ têm demonstrado que pacientes com irc apresentam maior acúmulo da mesma e, devido à alta concentração de uréia presente na saliva destes pacientes, possuem grande quantidade de cálculo dentário, assim como tendência de hálito urêmico. Sendo o biofilme dental o fator primordial para desenvolvimento da doença periodontal (dp), ela também se mostrou prevalente em portadores de drc e pode ser dividida em dois diferentes grupos: gengivites e periodontites. As gengivites caracterizam-se por eritema, edema e alargamento do tecido gengival, e são reversíveis com o tratamento. A periodontite caracteriza-se pela reabsorção do osso alveolar que dá suporte aos dentes. Os micro-organismos anaeróbicos gram-negativos são a principal causa da perda óssea. A presença da bolsa periodontal é o sinal chave para o diagnóstico da periodontite e, em muitos casos, ocasiona mobilidade dentária ${ }^{9}$.

A prevalência e a severidade da periodontite têm sido descritas como sendo mais prevalentes em pacientes renais crônicos do que na população em geral ${ }^{9}$. A periodontite tem sido associada a uma resposta inflamatória sistêmica aumentada na população geral, e a análise dos dados do national health and nutrition examination survey iii (nhanes iii) encontrou uma associação positiva entre níveis elevados de marcadores do estado inflamatório, como proteína c-reativa, e severidade da doença periodontal 9 .

Os fatores de risco para a doença renal crônica incluem idade acima de 60 anos, hipertensão arterial, diabete mellitus, controle glicêmico, obesidade, microalbuminúrica, tabagismo, proteína c-reativa elevada, colesterol total elevado, baixos níveis de hdl, níveis elevados de Idl, densidade da lipoproteína, síndrome cardiometabólica, raça/etnia, genética. Dentre os fatores de risco não tradicionais que possam contribuir com a drc, atualmente estão incluídos a doença periodontal ${ }^{1}$.

É recomendado por alguns autores ${ }^{10}$ o uso de profilaxia antibiótica antes do tratamento odontológico, já que a distribuição dos principais agentes infecciosos nos indivíduos imunossuprimidos é $50 \%$ viral, $47 \%$ bacteriano e $3 \%$ fúngico. Convém ressaltar que os pacientes que realizam hemodiálise costumam apresentar diminuição no número de plaquetas, diminuição do fator iii, tempo de sangramento 
prolongado e ainda fazer uso de anticoagulante. Desta forma para se evitar hemorragias recomendase 0 atendimento odontológico no dia seguinte à hemodiálise.

Deve haver também cuidados para a fase pós-transplante evitando procedimentos mais invasivos por um período de 6 (seis) meses. O profissional deve estar atento à pressão arterial do paciente, uma vez que o uso da ciclosporina pode levar a um quadro de hipertensão ${ }^{10}$.

O indivíduo que descuida de sua saúde bucal pode apresentar problemas clínicos mais graves no curso da drc. Isso pode se dar devido à idade usualmente mais avançada dos pacientes, à ocorrência de comorbidades comuns, tais como o diabetes mellitus, à necessidade frequente do uso de múltiplas medicações e a um estado de disfunção imune. Assim, o desleixo com a saúde bucal pode constituir um importante e inobservado problema clínico $^{11}$. O presente estudo objetivou avaliar a condição periodontal em pacientes com drc por meio da verificação do nível de inserção clínica.

\section{METODOLOGIA}

Esta pesquisa tratou-se de um estudo descritivo, transversal, de caráter quantitativo, para análise da situação periodontal de pacientes de ambos os sexos, portadores de doença renal crônica. Sendo observados 180 pacientes não transplantados, portadores de doença renal crônica e que são submetidos à hemodiálise no centro de nefrologia do maranhão - cenefron, situado na região metropolitana da cidade de são luís/ma, no período de agosto a novembro de 2015.

$\mathrm{Na}$ abordagem do paciente foi fornecido informações sobre os objetivos da pesquisa, justificativas, e apresentado o termo de consentimento livre e esclarecido (tcle) (apendice b). Os pacientes responderam um questionário/entrevista ${ }^{12}$, contendo questões sobre dados pessoais, hábitos de higiene bucal, frequência de escovação dentária e uso de fio dental, também foram colhidas informações sobre o tempo de tratamento hemodialítico (apendice a). Após a entrevista, foi realizado o exame clínico bucal do paciente.

Foram incluídos neste estudo, 180 pacientes dos quais 80 não se encontraram nos critérios de inclusão da pesquisa. Foram considerados como critérios de inclusão pacientes com doença renal crônica e em tratamento hemodialítico, que concordaram e assinaram o tcle, possuíam os elementos dentários suficientes, sendo no mínimo 3 elementos, para ser submetido a avaliação do índice de doença periodontal, que se encontravam em uma condição sistêmica que permitia o exame periodontal. Os pacientes fumantes foram excluídos por causa da influência do tabaco no curso da doença periodontal, bem como diabéticos, edêntulos e pacientes que fazem uso de ciclosporina, nifedipina, 
fenitoína ou de qualquer outro medicamento reconhecidamente causador de alterações no tecido gengival.

Por se tratar de pesquisa envolvendo seres humanos, esta pesquisa foi aprovada pelo comitê de ética em pesquisa da universidade ceuma, são luís - ma, sob o protocolo no 1.180.293/2015 (anexo a). Para realização da pesquisa foi anexado ao questionário um termo de consentimento livre e esclarecido (apêndice b), informando ao participante o conteúdo da pesquisa, bem como a garantia de sigilo das informações e que o mesmo estaria livre para desistir do processo em qualquer momento.

Os exames clínicos foram realizados sob luz natural, por um único examinador previamente treinado, utilizando-se um espelho bucal clínico e uma sonda periodontal milimetrada de willians convencional com área codificada em preto de 1,0 a 10,0 mm.

Na análise da classificação da doença periodontal segundo a aap 1999, foram analisados o periograma por completo, analisando se o paciente possuía ou não doença. Caso houvesse doença foram analisados a severidade e a localização no que se refere a doença periodontal e índice de placa.

Para análises estatísticas os dados foram tabulados e analisados no programa stata 12.0 , seguido pelo teste exato do qui-quadrado, com nível de significância de $95 \%(p<0,05)$.

\section{RESULTADOS}

Os resultados foram organizados através de gráficos que demonstram a análise descritiva da prevalência da doença periodontal em pacientes com doença renal crônica sob tratamento de hemodiálise segundo o perfil, hábitos de higiene e sobre o tratamento de hemodiálise em são luís, maranhão, de agosto a novembro de 2015 ( $n=100)$.

Na maioria dos pacientes avaliados a doença mais frequente foi periodontite crônica leve localizada 44\%, seguida de periodontite crônica moderada localizada 23\% (gráfico 1).

Quanto a distribuição do número de pacientes abordados segundo o sexo do paciente, a maioria dos pacientes abordados era do sexo feminino representando $58 \%$, já o sexo masculino somou $42 \%$ (gráfico 2).

Em relação à distribuição do número de pacientes abordados segundo o tempo de hemodiálise a maioria ficou entre 1 a 2 anos, somando 69\% (gráfico 3) 
Quanto a distribuição do número de pacientes abordados segundo a quantidade de idas ao dentista, grande parte dos pacientes já não haviam comparecido aos dentistas entre 1 a 2 anos, somando um percentual de $56 \%$ (gráfico 4)

Sobre a distribuição do número de pacientes abordados segundo a crença que a doença periodontal possui relação com a doença renal crônica mais da metade dos entrevistados acreditam que a doença periodontal pode ocasionar um agravo na doença renal crônica, totalizando 51\% (gráfico 5).

E quanto a distribuição do número de pacientes em relação da doença periodontal e tempo de hemodiálise foi encontrado que a doença mais frequente foi periodontite crônica leve localizada em pacientes sob tratamento de 1 a 2 anos sendo $32 \%$. (gráfico 6)

\section{DISCUSSÃO}

A literatura estudada indica que pacientes renais crônicos apresentam algumas alterações da saúde bucal, tais como: elevado acúmulo de placa e cálculo dentário, diminuição da secreção salivar, hálito urêmico, palidez da mucosa bucal.

No presente estudo, o índice de placa nos pacientes em hemodiálise foi considerado alto, baseado no índice de o'leary, com média de 72,94\%. Tais resultados concordam com um estudo realizado em 2002 ${ }^{13}$, discordando, porém, de pesquisas do ano de $2003^{15}$.

a explicação para o maior acúmulo de placa em pacientes renais crônicos seria o fato de que eles se preocupam tanto com a condição sistêmica que negligenciam a saúde bucal ${ }^{14}$. Este resultado evidencia a deficiência na higiene bucal desses pacientes, devendo-se, portanto, priorizar um programa de promoção de saúde bucal a estes pacientes tanto em ambiente hospitalar como em campanhas de saúde pública.

É de extrema importância a participação, o acompanhamento odontológico periódico e a manutenção de hábitos de higiene bucal adequados em pacientes com doença renal crônica, por acometerem estruturas do periodonto de proteção e/ou sustentação, tais resultados encontrados nesta referida pesquisa concordam com estudos realizados em $2014^{9}$, bem como em pesquisas mais antigas ${ }^{14}$, demonstrando essa conformidade necessária e essencial neste tipo de entendimento.

A presente pesquisa mostra que grande parte dos pacientes compareciam as visitas periódicas aos dentistas, fazendo com que não fossem afetados por alterações periodontais, no entanto, os que visitavam pouco o consultório foram afetados, embora realizassem a escovação dentária diária, isso 
não significou uma menor ocorrência de doença periodontal, resultado semelhante foi encontrado por marakogulu ${ }^{16}$, demonstrando que mesmo realizando higiene bucal, os pacientes com doença renal crônica possuem alterações periodontais significativas com a presença de cálculo dentário.

A pobre saúde bucal em pacientes renais crônicos em diálise foi observada também nas pesquisas de meyerowitz ${ }^{17}$, os quais comentaram que pacientes renais crônicos em hemodiálise geralmente não apresentam saúde bucal aceitável, justificando que tais pacientes não buscam serviços odontológicos regularmente, somente os utilizando em casos de urgência, necessitando de atenção odontológica especial e conscientização de que as infecções bucais podem trazer sérias complicações ao quadro sistêmico em pacientes renais crônicos por representarem focos de infecção.

Correlacionando o presente estudo com um semelhante feito na cidade de imperatriz- ma, no ano de 2014, obtiveram alguns resultados similares e outros diferentes, ficando claro que na cidade de imperatriz a maioria dos pacientes eram homens, $72 \%$, e no presente estudo a maioria são pacientes do sexo feminino, com 58\%, em imperatriz o tempo de hemodiálise variava entre 3 a 5 anos, enquanto que em são luís a variação foi entre 1 a 2 anos, porém obtiveram resultados semelhantes em relação ao tempo de idas ao cirurgião - dentista , 67,4\% afirmaram que não vão ao cirurgião dentista nem uma vez por ano, na pesquisa feita na cidade de imperatriz, assemelhando-se aos $56 \%$ obtidos na capital maranhense. Em imperatriz foram encontradas que as doenças mais frequentes eram periodontite crônica moderada e severa sendo respectivamente $37 \%$ e $40 \%$, em pacientes com mais tempo de hemodiálise. Enquanto que em são luís as mais frequentes foram periodontite crônica ${ }^{18}$

GRÁFICO 1- Distribuição do número de doenças periodontais encontradas

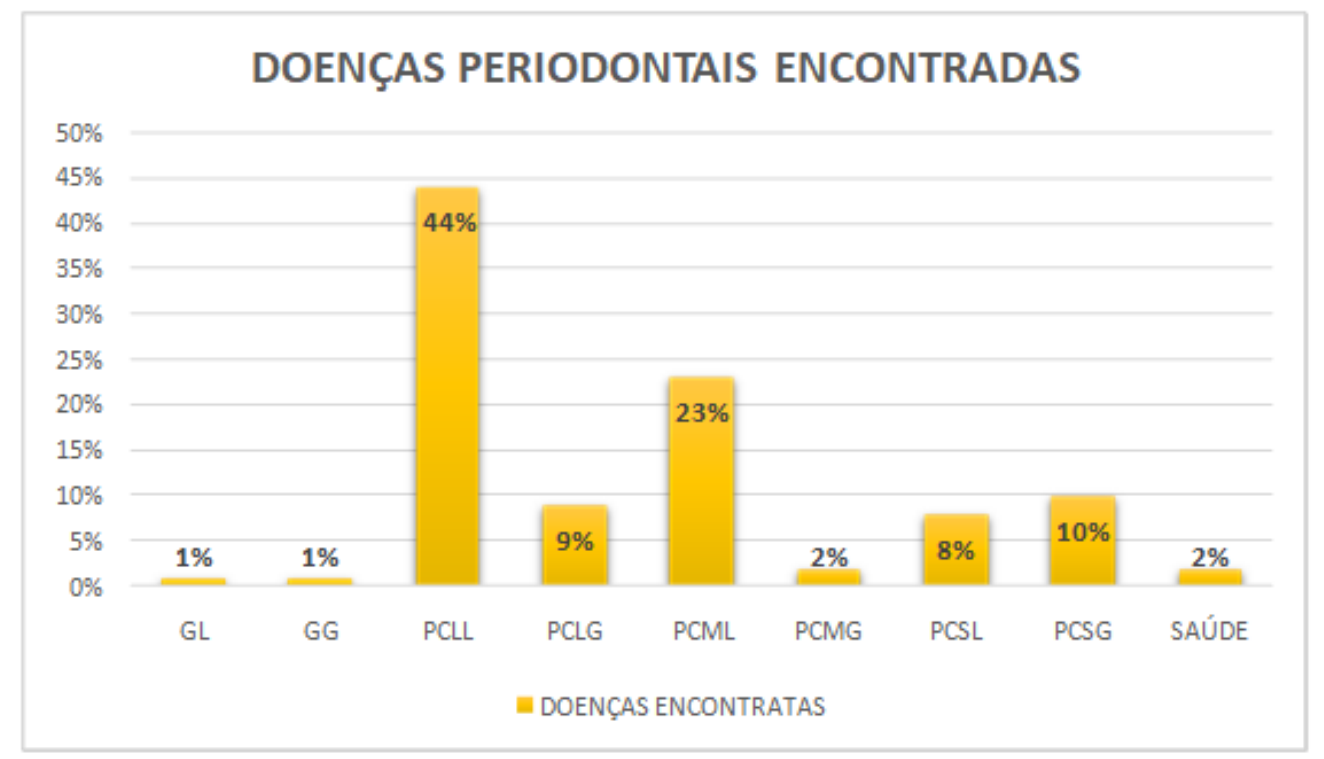


GRÁFICO 2- Distribuição do número de pacientes abordados segundo o sexo do paciente

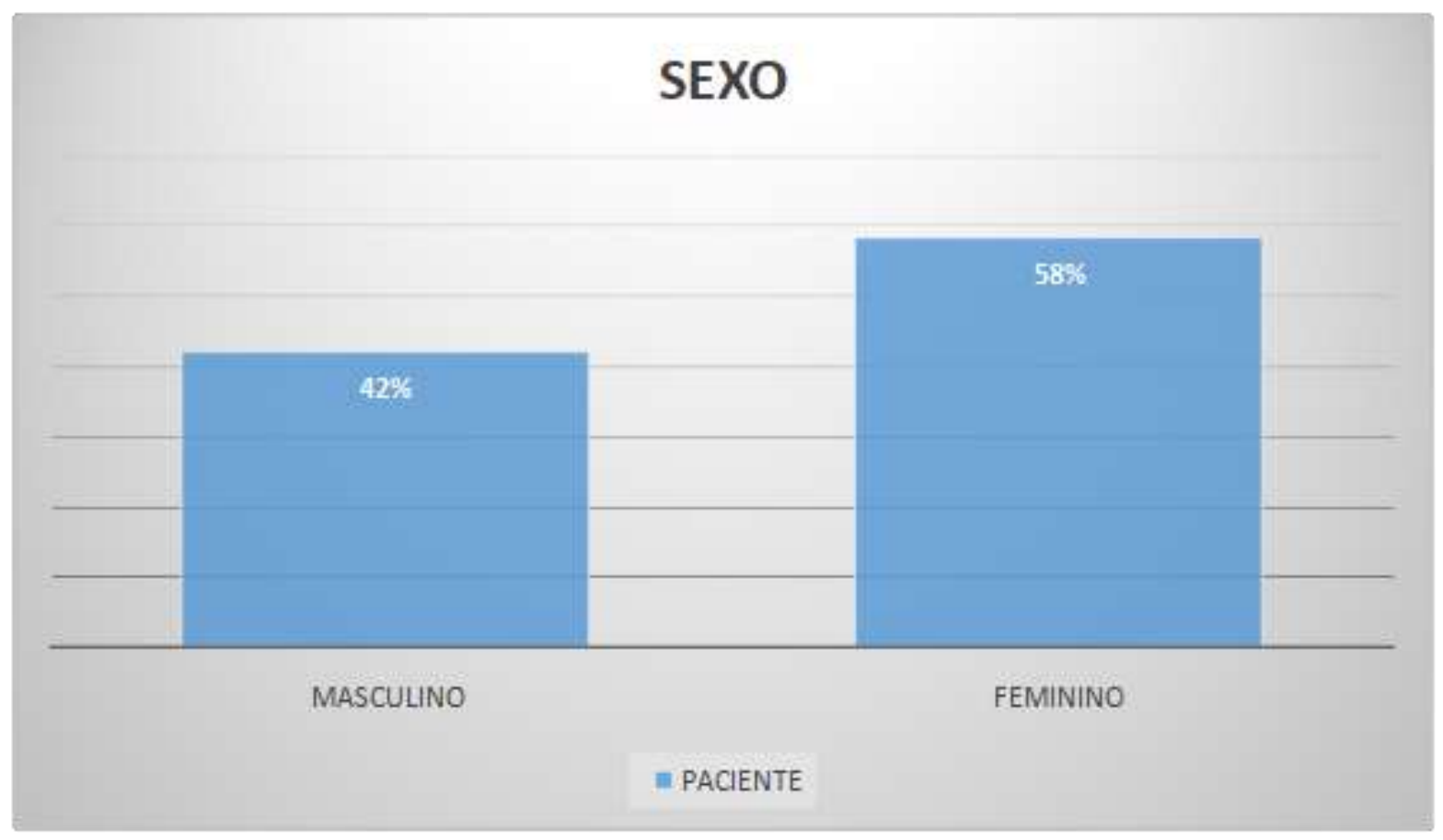

GRÁFICO 3- Distribuição do número de pacientes abordados segundo o tempo de hemodiálise

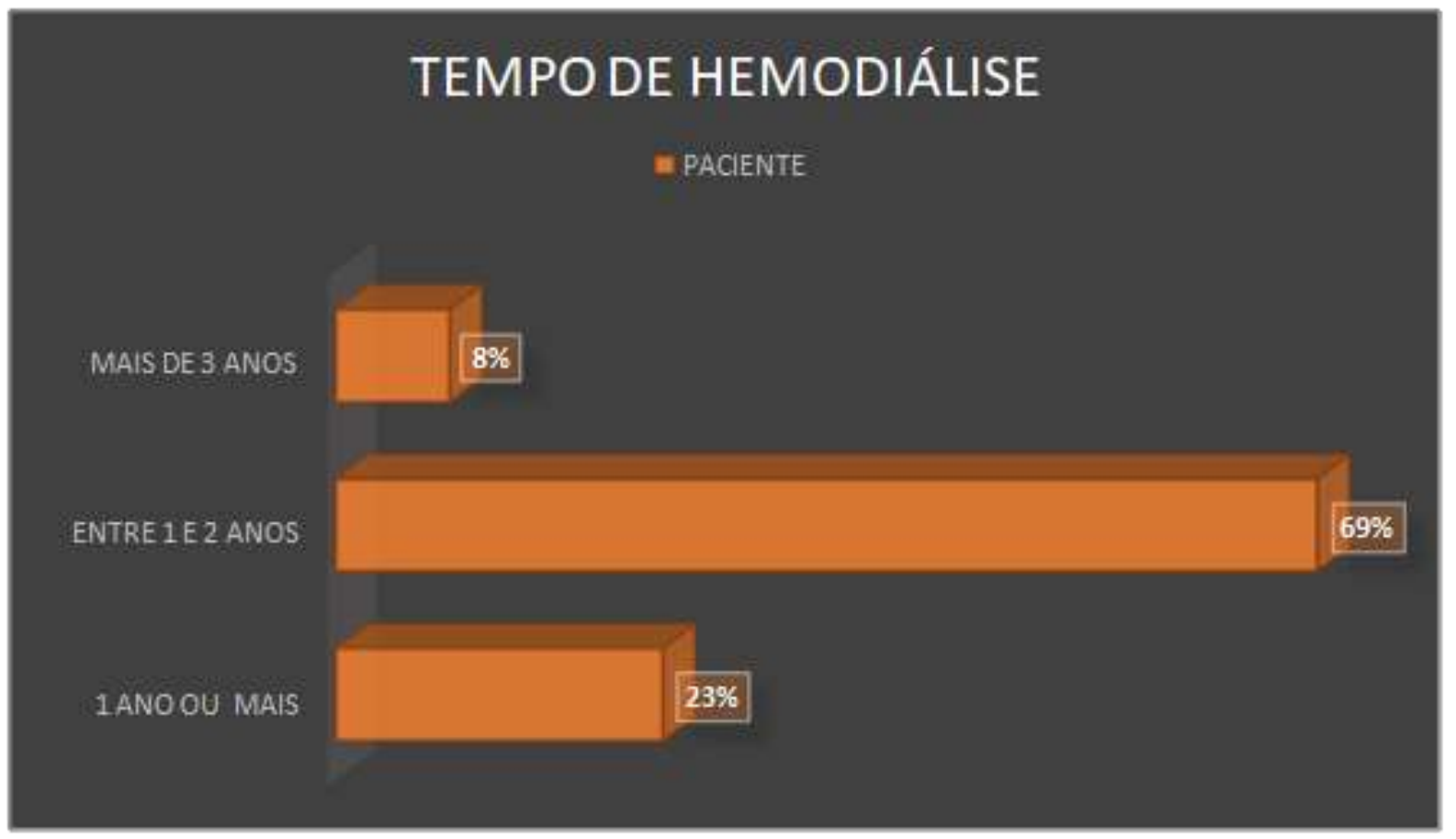


GRÁFICO 4- Distribuição do número de pacientes abordados segundo a quantidade de idas ao dentista

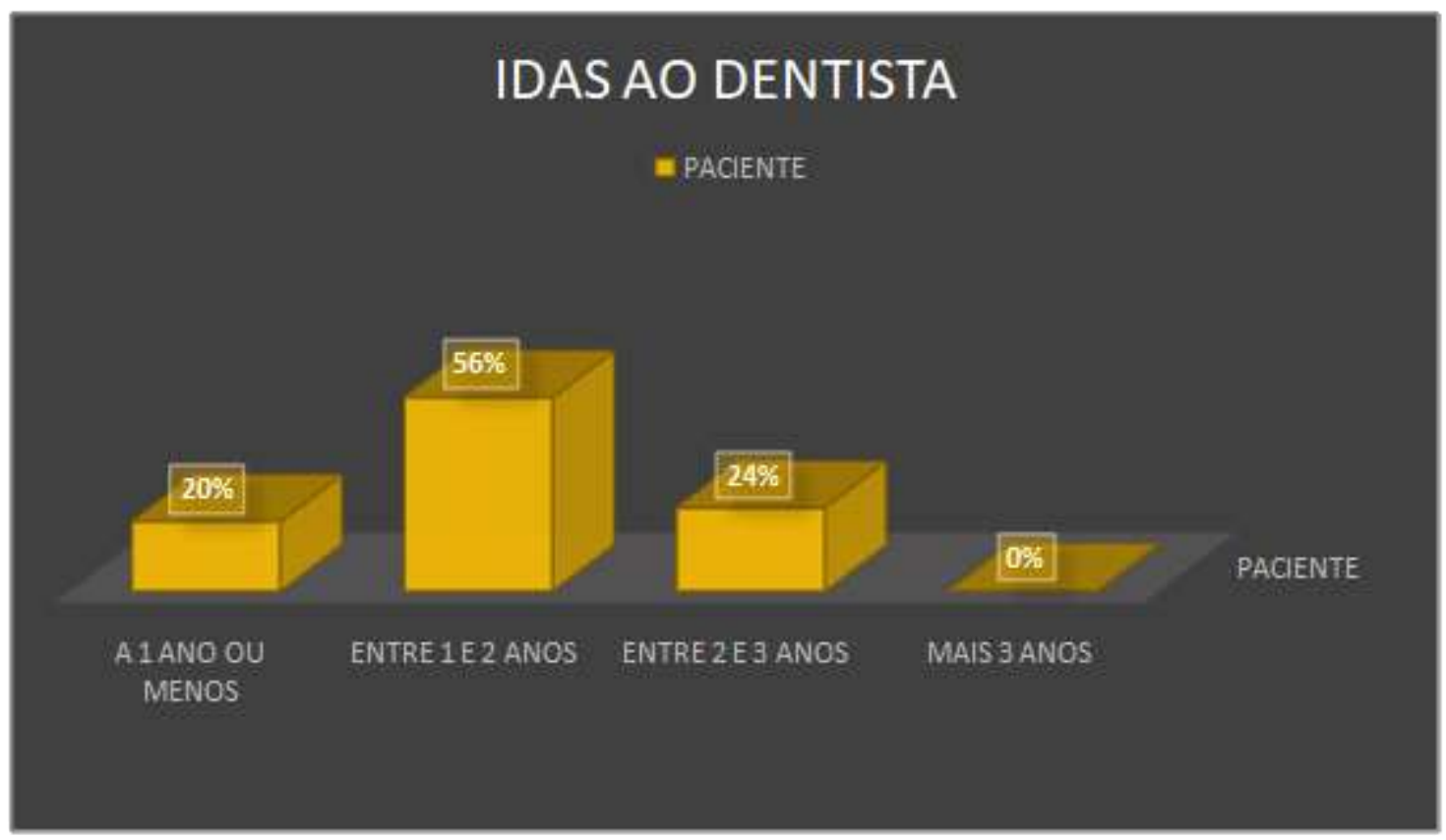

GRÁFICO 5- Distribuição do número de pacientes abordados segundo a crença que a doença periodontal possui relação com a doença renal crônica

\section{DPX DRC}

\section{- PACIENTE}

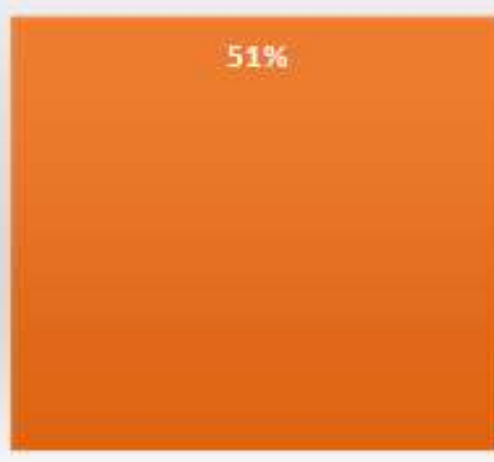


GRÁFICO 6- Distribuição do número de pacientes em relação da doença periodontal e tempo de hemodiálise

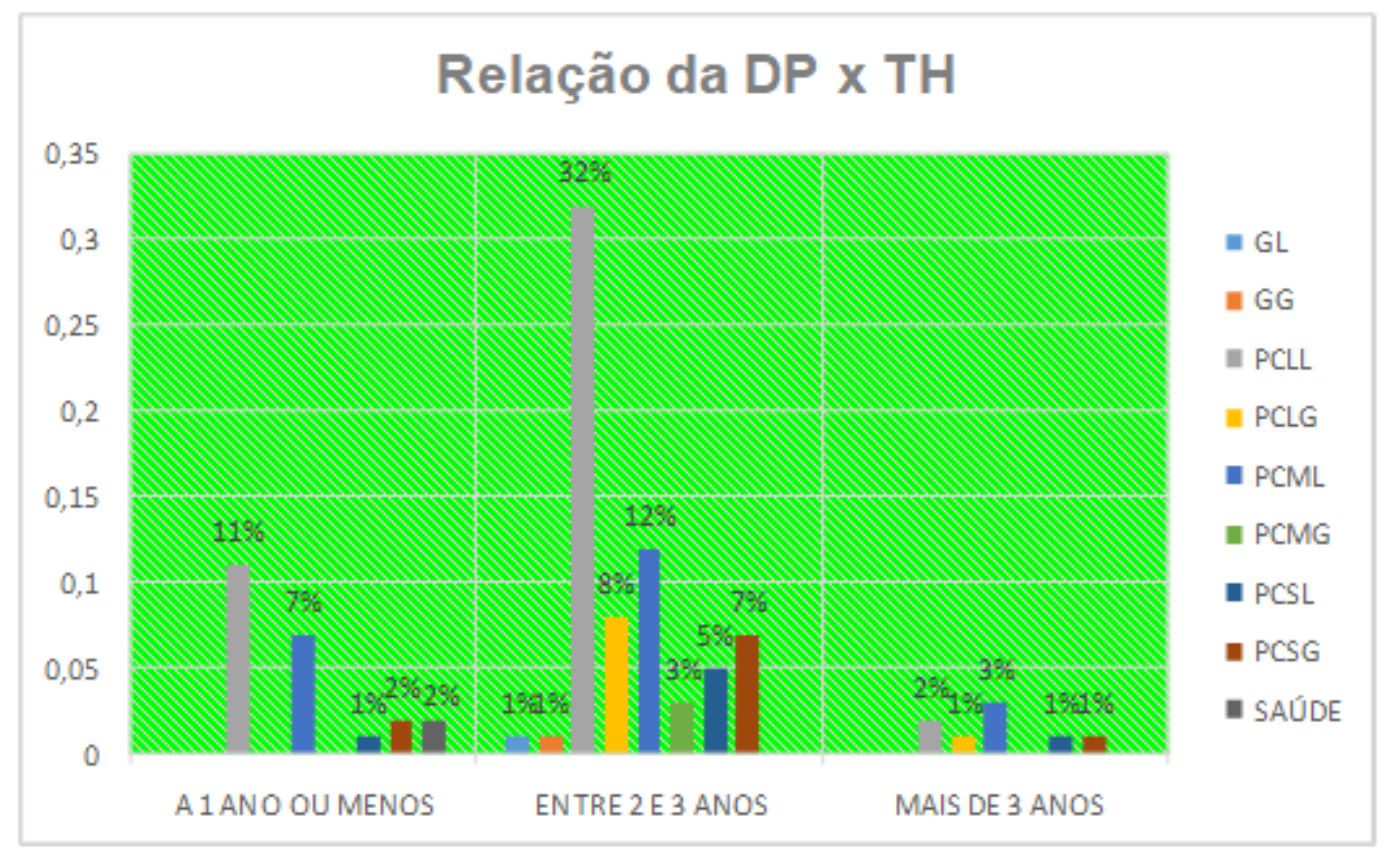




\section{REFERÊNCIAS}

1. Almeida, s r b. Doença renal crônica. Uerj,2011.

2. Sesso, r. C et al. Dos; relatório do censo brasileiro de diálise de 2010, j bras nefrol, [s.l] 2011; v. 33 pág. 442-447.

3. Chen Ip, et al. Does periodontitis reflect inflammation and malnutrition status in hemodialysis patients? Am j kidney dis [s.I] 2006; 47: 815-822.

4. Chonchol $\mathrm{m}$, et al. Association of inflammation with anaemia in patients with chronic kidney disease not requiring chronic dialysis. Nephrol dial transplant. [s.I] 2008 set; 23 (9):2879-83.

5. D'ajuto

6. Cilkuba r, racek j. Metabolic disorders in patient with chronic kidney failure. Phisiol res 2007; 56(6):697-705.

7. Kovesdy cp. Rate of kidney function decline associates with increased risk of death. Journal of the american society of nephrology; jasn 2010;21(11):1814-6.

8. Dias crs, et al. Análise comparativa da condição periodontal em pacientes renais crônicos e pacientes sismicamente saudáveis. Rev. Periodontia, 2007 são paulo - sp.

9. Lima dlf,et al. Análise epidemiológica da doença periodontal em pacientes cardiopatas isquêmicos no hospital de messejana, na cidade de fortaleza-ceará.periodontia 2011;14:17-21.

10. Sekiguchi rt et al. Tratamento periodontal no paciente transplantado. Atualização clinica em odontologia: periodontia, implantodontia e cirurgia bucomaxilofacial. São paulo, artes medicas, 2006.p.701-711.

11. Neto joão francisco tenori. Doença periodontal no paciente renal - revisão de literatura 2009.rev de periodontia, maceió - alagoas

12. Saba, eduardo chufji. Avaliação da condição da doença periodontal de pacientes sob hemodiálise, são paulo, 2014.

13. Klassen jt, krasko bm. The dental health status of dialysis patients. J can dental assoc 2002;68:34-8.

14. Naugler $k$ et al. The oral health status of individuals on renal dialysis. Ann periodontol 1998;3:197-205

15. Kitsou vk, konstantinidis a, siamopoulus kc. Chronic renal failure and periodontal disease. Renal failure 2003;22:307-18.

16. Marakoglu i et al. Periodontal status of chronic renal failure patients receiving hemodialysis. Yonsei med j 2003; 44:648-52 
17. Meyerowitz c. Cáries nos pacientes de diálise renal. In: bowen wh, tabak I. A cardiologia para a década de 90. São paulo: santos, 1995. P.249-60

18. Lima, marcia cristina pereira de sousa et al. Avaliação da condição periodontal de pacientes sob hemodiálise na cidade de imperatriz-ma. Arquivo med hosp fac cienc med santa casa são paulo, 2014. 
APÊNDICE

\section{QUESTIONÁRIO (APÊNDICE A)}

AVALIAÇÃO DA PREVALÊNCIA DA DOENÇA PERIODONTAL EM PACIENTES COM DOENÇA RENAL CRÔNICA SOB TRATAMENTO DE HEMODIÁLISE

PERFIL DO PACIENTE

1. NOME DO PACIENTE:

2. IDADE DO PACIENTE:

3. SEXO DO PACIENTE : ( )M ( )F

4. PROFISSÃO DO PACIENTE :

5. ESTADO CIVIL :

6. RAÇA DO PACIENTE

HÁBITOS DE HIGIENE :

1. QUANTAS VEZES O PACIENTE ESCOVA OS DENTES POR DIA?

( )1A2 ( )2A3 ( )3A4 ( )MAIS DE 4

2. O PACIENTE USA FIO DENTAL? QUANTAS VEZES?

( ) SIM ( )NÃO QUANTAS VEZES?

3.A GENGIVA DO PACIENTE SANGRA?

( )SIM ( )NÃO

4.O PACIENTE POSSUI MAU HÁLITO?

( )SIM ( )NÃO

5. JÁ FOI A DENTISTA?

( ) SIM ( ) NÃO

6. QUANTO TEMPO FAZ QUE VOCÊ FOI AO DENTISTA?

( ) A 1 ano ou menos ( ) Entre 1 a 2 anos ( ) Entre 2 a 3 anos ( ) Mais de 3 anos

SOBRE O TRATAMENTO DE HEMODIÁLISE 
7. A QUANTO TEMPO FAZ HEMODIÁLISE?

8. QUAL A FREQUENCIA?

9.VOCÊ ACREDITA QUE AS DOENÇAS PERIODONTAIS POSSAM

OCASIONAR UM AGRAVO NA DOENÇA RENAL CRÔNICA?

( ) $\operatorname{Sim}($ )Não

10. VOCÊ ACREDITA QUE A RASPAGEM PERIODONTAL AMENISA

DOENÇAS SISTÊMICAS?

( )SIM ( )NÃO

11.VOCÊ ACREDITA QUE A DOENÇA RENAL CRÔNICA É INFLUENCIADA POR CAUSA SANGRAMENTO GENGIVAL?

( ) $\operatorname{SIM~(~)NÃO~}$

12. QUAL (IS) CONDUTA(S) CLÍNICA(S) VOCÊ ADOTARIA PARA PREVENIR A PERIODONTITE ?

( ) Nenhuma conduta específica;

( ) ESCOVAÇÃO E FIO DENTAL;

( ) ESCOVAÇÃO;

( )ESCOVAÇÃO + FIO DENTAL+IDAS AO DENTISTA; 
APÊNDICE B - Termo de consentimento livre e esclarecido

\section{UNIVERSIDADE CEUMA \\ PRÓ-REITORIA ACADÊMICA \\ COORDENADORIA GERAL DE SAÚDE \\ COORDENADORIA DO CURSO DE ODONTOLOGIA}

A pesquisa intitulada "Avaliação da prevalência da doença periodontal em pacientes com doença renal crônica sob tratamento de hemodiálise", é um trabalho monográfico de conclusão do Curso de Odontologia da aluna Thaiane Caroline Nascimento Costa, sob orientação da Prof $^{\circ}$ Dra. Livia Helena de Araújo Castro Nunes. A mesma tem como objetivo Avaliar a prevalência de doença periodontal em uma população de pacientes com doença renal crônica submetidos à hemodiálise.

Sua participação é de fundamental importância para a concretização desta pesquisa, necessitando para tal, preenchimento de um questionário e avaliação clínica. A presente pesquisa não oferece riscos físicos, morais, financeiros, nem psicológicos aos participantes, bem como sua identidade permanecerá em sigilo. Você pode aceitar ou não participar do estudo sem nenhum prejuízo a sua assistência, e terá liberdade de retirar seu consentimento de participação da mesma. Os dados coletados serão apresentados somente em trabalho monográfico. 
ANEXOS

ANEXO I - Definição do tema do artigo cientifico e aceite do orientador

\title{
UNIVERSIDADE CEUMA \\ PRÓ- REITORIA ACADÊMICA \\ COORDENADORIA GERAL DE SAÚDE \\ COORDENADORIA DO CURSO DE ODONTOLOGIA
}

\author{
Aluno (a): Thaiane Caroline Nascimento Costa \\ CPD: 879265
}

Coordenadoria do Curso de Odontologia

Informo que o tema escolhido para meu artigo cientifico é: Avaliação da prevalência de doença periodontal em pacientes com doença renal crônica sob tratamento de hemodiálise e que conto com a concordância formal da professora: Lívia Helena de Araújo Castro Nunes em ser minha orientadora a partir desta data.

Declaro, na oportunidade, conhecer o cronograma de trabalhos da Coordenadoria do Curso, comprometo-me elaborar o Projeto de pesquisa dentro dos prazos e normas estipulados.

Atenciosamente,

Thaiane Caroline Nascimento Costa

ACEITE DA ORIENTADORA:

Castro Nunes

Prof $^{\circ}$ Dra. Lívia Helena de Araújo 
ANEXO II - Aprovação do comitê de ética 


\section{CENTRO UNIVERSITARIO DO MARANHĀO - UNICEUMA}

\section{PARECER CONSUBSTANCIADO DO CEP}

\section{DADOS DO PROJETO DE PESQUISA}

Titulo da Pesquisa: AVALIACAO DA PREVALENCIA DA DOENCA PERIODONTAL EM PACIENTES COM DOENCA RENAL CRONICA SOB TRATAMENTO DE HEMODIALISE

Pesquisador livia helene de araujo castro nunes

Área Tematica:

Versalo: 1

CAAE: 47535415.8 .0000 .5084

Instituiçăo Proponente: Centro Universitalio do Maranhâo - UniCEUMA

Patrocinador Principal: Financiamento Próprio

\section{DADOS DO PARECER}

\section{Nùmero do Parecer: 1.180 .293}

Data da Relatoria: 28/07/2015

\section{Apresentaçào do Projeto:}

No Brasil cs dados sobre a epidemiologia da DRC (Doenca Renal Crónica) se restringem aos pacientes sob terapia renal substitutiva Sáo alarmantes os nùmeros sobre a prevaléncia de pacientes em tratamento de hemodialise. Essa situaçalo mundial da DRC (Doença Renal Crỏnica) assume grande importância no que se refere a doença periodontal, por se tratar de uma doenca de carater infeccioso mulufatorial, associada como fator de risco para algumas doenças sistamicas (ALMEIDA et al, 2011)

Esse nùmero vem aumentando graduaimente ao longo dos anos, de 42.695, em 2000, a 92091 , em 2010. Mais da metade desses pacientes se encontrava na regiâo Sudeste. A taxa de prevalóncia do tratamento diatitico em 2010 for de 493 pacientes por milhao da populaçap (pmp), variando por regiaso entre 265 parcientes pmp na regiäo Norte a 591 pacientes pmp na Sudeste. O número estimado de pacientes que iniciaram tratamento em 2010 no Brasil foi de 18.972 , correspondendo a uma taxa de incidencia de 99.5 pacientes pmp (SESSO et at, 2011).

A Doença Renai Cronica é definida por anormalidades estruturais ou funcionais do rim, com ou sem diminuiçalo da Taxa de Funçlo Glomerular (TFG), evidenciada por ancrmalidades histopatologicas ou de marcadores de lesâo renal, incluindo alteragoes sanguineas ou urinârias, ou ainda de exames de imagem: TFG $<60 \mathrm{~mL} / \mathrm{min} / 1,73 \mathrm{~m} 2$ por um periodo igual ou superior a thés

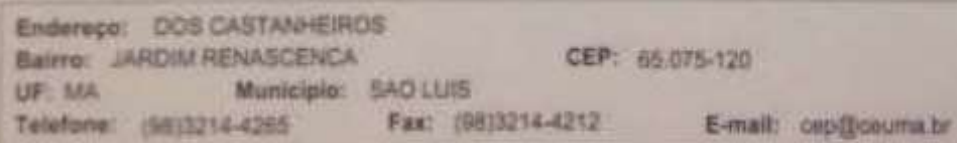




\section{CENTRO UNIVERSITARIO DO MARANHAOO - UNICEUMA

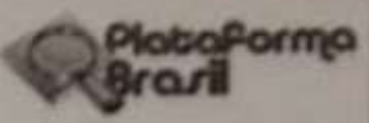

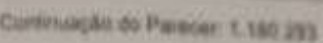

meses com ou stm lesdo renal (CHEN of al, 2006; CHONOHOL of at, 2006)

A DRC caracteriza-se por uma perda lenta, progressiva $s$ irreversivel da funchlo dos nefrons, desde a filtraçâo glomerular, o equilibrio da volnmia. o controlo da prossab arterial e dos eietrolcos, ate as capacidades endocrinas renais, desencadeando uma shrie de fenomenos humcrais e celuares, resulando no decilinio progressivo da taxa de fitraça giomerular, atb a perda da funclo renal ou Doença Rena! Crónica Terminal (DRCT) (DAJUTO et ai, 2004; CLLKUBA \& RACEX, 2007; KOVESOY, 2010).

Tais mudanças sistemicas podem reflefir no meio bucai, levando a altaracbers na composiclo sativar, com aumento dos niveis de ureia, potassio, fosfato e aumento dos niveis de Ch o Mg7: no nivel do flixo salivar. com diminuicaso do mesmo: no pH salivar, que pode ser mais alcalino, ra capacidade-tartpato, com aumento da mesma e elevada formaça de calculo dentario (DiAs of al. 2007).

Alem disso, a falta de culdados com a higiene bucal pode afetar a saude bucal destes pacientes. resultando om mais cáries, doenças penodontais e lesdes bucais. Nao ha consenso quanto a predisposiçalo destes pacientes a cante dentaria. Em pesquisa realizada por Bayraktar at at $(2010)$, foi observado que nao houve mudança quanto à ocorréncia de cárie dentaria. Ja no estudo de Naugle et al (2010), observou-se que a experiencia de carie dentaria foi eievada nos pacientes am dialise, enquanto que nas pesquisas realizadas por AI-Nowaiser et al (2007). Jaffe et al $(2007)$ e Davidovich et al $(2007)$, pacientes com IRC em dialise apresentaram menores incices de carie dentaria (DiAs et al, 2007).

Sabth-se ainda que a DRC pode exibir variadas manifestaçobs bucais como xerostomia, estomatite urêmica. aiteraçbes radiograficas dos ossos maxilares, formaçalo de caliculo dentario decorrente do aumento da concentração de fostato 0 cátcio sérico e outras menos frequètes (DIAS et al, 2007 b).

Segundo Dias at al (2007), com relaçlo a presença de placa bacteriana, alguns estudos tèm demonstrado que pacientes com IRC apresentam maior acúmulo da mesma e, devido a aifa concentraçâo de ureia presente na saliva destes pacientes, possuem grande quantidade de calculo dentário, assim como tendericia de halito urèmico.

Sendo o biofilme dental o fator primordial para desenvolvimento da doença periodontal (DP), ela tamberm se mostrou prevalente em portadores de DRC e pode ser dividida em dois dilerentes grupos: gangivites $\theta$ periodontites, As gengivites caracterizam-se por efitema, edema e aiargamento do tecido gengival, e săo reversiveis com o tratamento. A periodontite caracteriza-se pela reabsorçâo do osso alveolar que da suporte aos dentes. Os micro-organismos anaordbicos

Enderego: DOS CAsThaHEROS

Gaims JaRDAM REGASCENCA

UF $\mathrm{MA}$ Municiple: sho Luis

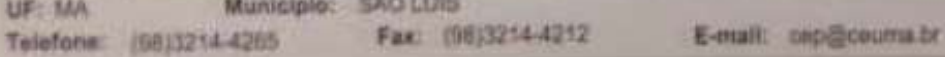




\section{CENTRO UNIVERSITARIO DO Ploboformo MARANHAOO - UNICEUMA}

Cersinublo so Pracer itac as

gram-negativos sà a principal causa da perda ossea. A presença da bolsa periodontal e o sinal chave para o diagnóstico da periodontite e, em muitos casos, ocasiona mobilidade dentaria (LMA et al., 2011)

A prevalencia e a severidade da periodontite têm sido descritas como sendo mas prevalentes am pacientes renais crónicos do que na populaça em geral (LMA at al, 2011). A periodontite tem sido associada a uma resposta inflamatoria sistemica aumentada na populapabo geral, e a analise dos dados do National Health and Nutrition Examination Survey III (NHANES Iii) encontrou uma associaçోo positiva entre niveit elevados de marcadores do estado inflamatorio, como proteina C-reativa, e severidade da doença periodontat, 0 presente estudo objetivou avaliar a condiça periodontal em pacientes com DRC por meio da verficaçlo do nivel de inserça clinica (LIMA ot al, 2011).

Os fatores de risco para a doença renal crónica incluem idade acima de 60 snos, hipertensalo arteria! ciabete melitus, controle glicêrnico, obesidade, macroalbuminüria, tabagismo, proteina C-reativa elevada. colesterol total elevado, baixos niveis de HDL, niveis elevados de LOL densidade da lpoproteina. sindrome cardiometabolica, raçaletnia, genetica. Dentre os fatores de risco nao tradicionais que possam contribuir com a DRC, atuaimente estäo incluidos a doença periodontal (ALMEIDA et al. 2011)

Sekiguchi et al. (2006), recomendam assim, o uso de profilaxia antibibtica antes do tratamento odontoldgico, ja que a distribuiça dos principaks agentes infecciosos nos individuos imunossuprimidos $e$ $50 \%$ viral, $47 \%$ bacteriano e $3 \%$ fúngico. Convêm ressaltar que os pacientes que realizam hemodialise costumam apresentar diminuiçâo no nùmero de plaquetas, diminuiçào do fator lli., tempo do sangramento prolongado e ainda fazer uso de anticoagulante. Desta forma para se evitar hemorragias recomenda-se o atendimento odontologico no dia seguinte à hemodialise.

Deve haver tambêm cuidados para a fase pós-transplante evitando procedimentos mais invasivos por um periodo de 6 meses. O profissional deve estar atento á pressäo arterial do paciente, uma vez que o uso da ciclosporina pode levar a um quadro de hipertensào (Sekiguchi et al, 2006).

Kshirsagar et al., (2007), avaliaram os indices de IgG para 17 microrganismos inciuldos nos complexos vermelho e taranja de bactérias, Elevados indices sêricos de igG para patogenos periodontais especificos incluindo Porphyromonas gengivalis. Treponema denticola e Aggregatibacter actinomycelemcomitans foram encontrados em individuos com uma baika taxa estimada de filtraça glomerular (eGFR) $<60 \mathrm{~m} / / \mathrm{min} / 1,73$ $\mathrm{m}^{2}$ (eGFR > $60 \mathrm{mi} / \mathrm{min} / 1.73 \mathrm{~m}^{2}$ padrăo de normalidade). Estes microrganismos foram comumente associados com uma reduçào na funçầo

Enderęo: DOS CASTAWHEIROS Bairro: JAROIM RENASCENCA

UF: $M A \quad$ Municiplo SAOLAS

CEP: $65.075-120$

Telefone: (98)3214-4265 Fax (B8)3214-4212 E-mail ceptgonurato 


\section{CENTRO UNIVERSITARIO DO MARANHAOO - UNICEUMA}

Cintinass as Fewe is thas

Tenat comparados com incividuos que aptesentaram baxos silulos de anteorpos para os meshos

Segundo Kshirsagar et al. (2007), paldogenos periodontais podem causar danos para a unidsoe do netro ou

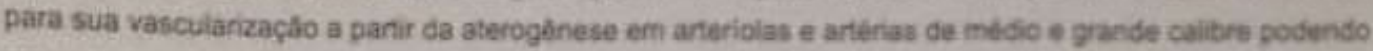
ocorrer isquemia, giomenulonecrose e insuficléncia renal severa.

O individuo que descuida de sua saude bucal pode apresentar proclemas clínicos mais groves no cano da DRC. Isso pode se dar devido a idade usualmente mais avançads dos pacientes, a scorrencia de comor oidades comuns, tais como a diabetes metitus, a nevcessidado frequente do uaso de mulipias medicaçő́es e a um estado de disfunçăo imune. Assim, o desleixo com a saude bucal pode constituir um importante $\theta$ inotservado problema clinico (Nato, 2009).

Desta forma, questiona-se: existe uma associaça ontre dconça renal cotinica e doença periodontar? Quais os riscos que podem acometer esses pacientes associados a esta patologla?

Torna-se, portanto, necessario que se propague e se confirme a idela de uma possival associaçbo antre a doença renal ctónica e a doença periodontal, para que profissionais da saude sutejan alartas guanto aot riscos que corre um paciente com a associacho dessas putologias. Para tanto, visando acallar as denvals a. ainda, escassos estudos sobre o tema, o objetivo deste trabalho fol avaliar a prevalencia de doenca periodontal am uma populaçlo de pacientes com doença renal crónica submetido a hemodialise

\section{Objetivo da Pesquisa:}

Avaliar a prevalência da doença periodontal em uma populacho de pocientes coms doença renal crónica submefidos a hemodialise.

\section{Avaliaçăo dos Riscos e Beneficios:}

E possivel que ocorra leve sangramento gengival no mornento do exame clinico e desconitorto na adaptaça do fitme radiografico E existe um pequeno incomodo no momento da coleta do exame, peia picada da agulha. $O$ risco de infecgao o desprezivel, pois a coleta de sangue sera realizada por profissionais habititados e com materiais descartaveis do proprio laboratorio da Universidade

Os pacientes com doenças de gengival receberabo tratamento periodontal básico (orientaçao á escovaças, dieta, limpeza e aplicaçăo de flcior) ou tratamento periodontal intensivo (orientaçăo à escovaçao, dieta. remoça de tartaro acima e abaixo da gengiva e aplicaça de flùor) no gabinete odontologico da Universidade CEUMA.

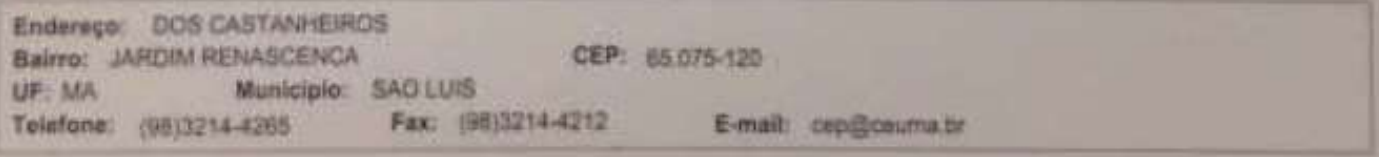




\section{CENTRO UNIVERSITÁRIO DO MARANHĀO - UNICEUMA}

Comenasadas Pwece t.150\%s.

\section{Comentarios e Consideraços sobre a Pesquisa:}

A pesquisa possui relevâncla cientifica e estâ estrufurada de acordo com a Resoluçlo $466 / 2012$ do Conselho Nacionai de Sacide, que norteia sobre a pesquisa envobiendo seres humanos. $O$ presente projeto apresenta como itens: Introduço; Justificativa; Hipoteses; Rösco o Beneficios: Cronogramac Orçarnento o Termos Obrigatonos

Consideraçbes sobre os Termos de apresentaçào obrigatoria:

A pesquisadora anexou todos os termos de apresentaçăo obrigatbria necessarios para a aprovaça do projeto.

\section{Recomendaçōes:}

Nảo hà

Conclusōes ou Pendēncias e Lista de Inadequaçóes:

Projeto aprovado sem pendéncias.

\section{Situaçalo do Parecer:}

Aprovado

Necessita Apreciaçăo da CONEP:

Nao

Consideraçoes Finais a critério do CEP:

SAO LUIS, 11 de Agosto de 2015

Assinado por:
Eduardo Durans Figuerddo
(Coordenader)

EnderEGo: DOS CASTANHEIROS

Baimo: JARDIM RENASCEN.CA

UF: MA Municiplo: SAO cuis

Telofone: (B8)9214.42t5

Fax: $(90) 3214-4212$

CEP: 65075-120

do Durans Figuerddo

(Coordenader) 
ANEXO III - Normas da revista trabalho, educação e saúde

\section{Diretrizes para o autor}

\section{Escopo e política}

A Revista Trabalho, Educação e Saúde é editada pela Escola Politécnica de Saúde Joaquim Venâncio, da Fundação Oswaldo Cruz. Destina-se à publicação, com periodicidade quadrimestral, de debates, análises e investigações, de caráter teórico ou aplicado, sobre temas relacionados à educação profissional em saúde. A política editorial da revista consiste em discutir esta área sob a ótica da organização do mundo do trabalho, de uma perspectiva crítica, sistemática e interdisciplinar.

\section{Forma e preparação de manuscritos}

\section{A revista aceita contribuições inéditas dos seguintes tipos:}

Ensaios: Produção textual de amplo alcance teórico-analítico, não conclusivo e não exaustivo. Tamanho: 6.000 a 10.000 palavras, incluindo referências bibliográficas, figuras e notas.

Artigos: Apresentação de resultado de pesquisa de natureza empírica ou conceitual. Tamanho: 4.000 a 8.000 palavras, incluindo referências bibliográficas, figuras e notas.

Debates: Discussão sobre temas específicos, tanto encomendados pelos editores a dois ou mais autores, quanto advindos de colaboradores. Tamanho: até 5.000 palavras, incluindo referências bibliográficas, figuras e notas.

Entrevistas: Opinião ou posição de entrevistado qualificado nas áreas de conhecimento da revista. 
Resenhas: Crítica de livro relacionado aos campos de confluência da revista, publicado ou traduzido nos últimos três anos. Tamanho: até 1.500 palavras.

\section{Apresentação do manuscrito}

Colaborações devem ser digitadas no Word, na fonte Times New Roman, em corpo 12, em espaço duplo. Artigos, ensaios e debates devem ainda conter um resumo em português e em inglês (abstract) de, no máximo, 200 palavras, e título em inglês, além do título na língua original. Os manuscritos podem ser apresentados em português, espanhol, inglês e francês. O título deve ser conciso e representativo do conteúdo do texto. $O(s)$ autor(es) deve $(\mathrm{m})$ indicar se a pesquisa é financiada, se é resultado de dissertação de mestrado ou tese de doutorado, se foi aprovada por Comitê de Ética da área e se há conflitos de interesse.

Palavras-chave: Mínimo de três e máximo de cinco palavras-chave descritoras do conteúdo do trabalho, apresentadas na língua original, em espanhol e em inglês (keywords).

Figuras: Tabelas, quadros, diagramas, fotografias, gráficos e ilustrações não devem ultrapassar o máximo de seis por artigo, salvo exceções específicas ao campo temático do manuscrito, caso em que o autor deverá manter uma comunicação prévia com os editores. Todas as figuras, com exceção de fotografias, devem ser numeradas e ter título, estando apenas as iniciais do título em maiúsculas. As referências devem ser feitas através de números (ex. gráfico 3) e não por expressões como "a figura abaixo".

Notas: As notas devem vir ao fim do texto, numeradas de forma consecutiva. As notas não devem ser utilizadas para referências bibliográficas.

Grifos: Solicita-se a não utilização de sublinhados e negritos. As aspas simples podem ser usadas para chamar a atenção para um item particular do texto. 
Palavras de outras línguas, que não o português, devem ser italicizadas, assim como títulos de obras mencionadas.

Citações: Citação no corpo do texto deve vir marcada com aspas duplas, com sobrenome do autor, ano e página, como no exemplo (Bourdieu, 1983, p. 126); citação com autor incluído no texto deve vir Gramsci (1982); citação com autor não incluído no texto será (Frigotto e Ciavatta, 2001). No caso de citação com mais de três autores, somente o sobrenome do primeiro deverá aparecer no texto, como em Spink et al. (2001).

Referências: Para elaboração das referências, Trabalho, Educação e Saúde adota a norma NBR 6023, da Associação Brasileira de Normas Técnicas (ABNT). Todas as referências citadas, inclusive nas notas, nos quadros e nas figuras, deverão compor as referências bibliográficas ao fim do texto, em ordem alfabética, sem numeração de entrada e sem espaço entre elas. Nas referências serão citados, no máximo, até três autores com todos os nomes. No caso de mais de três autores, citar apenas o primeiro, seguido da expressão et al. O primeiro nome dos autores deve ser escrito por extenso nas referências. Diferentes títulos de um mesmo autor publicados no mesmo ano deverão ser distinguidos, adicionando-se uma letra ( $a, b, c . .$.$) em minúscula$ após a data, tanto nas citações no corpo do texto quanto na lista de referências bibliográficas. Observem-se os exemplos a seguir:

- Artigo

AROUCA, Antônio Sergio. Quanto vale a saúde dos trabalhadores. Saúde em Debate, Rio de Janeiro, v. 8, n. 3, p. 243-265, dez. 1995-mar. 1996. SPINK, Mary J. P. et al. A construção da Aids-notícia. Cadernos de Saúde Pública, Rio de Janeiro, v. 17, n. 4, p. 851-862, 2001.

- Livro e Tese

GRAMSCI, Antonio. Os intelectuais e a organização da cultura. 4. ed. Rio de Janeiro: Civilização Brasileira, 1982.

MENDES-GONÇALVES, Ricardo Bruno. Medicina e história: raízes sociais do trabalho do médico. Dissertação (Mestrado em Medicina Preventiva). São 
Paulo: Faculdade de Medicina, USP, 1979.

- Capítulo de livro

BOURDIEU, Pierre. O campo científico. In: ORTIZ, Renato (Org.). Pierre Bourdieu: sociologia. São Paulo: Ática, 1983. p. 122-155.

-Resumo de congressos

LAURELL, Asa Cristina. O Estado e a garantia do direito à saúde. In: CONGRESSO BRASILEIRO DE SAÚDE COLETIVA, 8., 2006, Rio de Janeiro. Anais... Rio de Janeiro: Abrasco, 2006. 1 CD-ROM.

-Dados fornecidos por agências governamentais

(secretarias, ministérios, IBGE, etc.)

RIO DE JANEIRO. Secretaria Municipal de Saúde do Rio de Janeiro (SMS$\mathrm{RJ}$ ). Dados sobre acidentes ocupacionais com material biológico. Rio de Janeiro: SMS-RJ, 2000.

-Leis, decretos, portarias etc.

BRASIL. Lei n. 9.394, de 20 de dezembro de 1996. Estabelece as Diretrizes e Bases

da Educação Nacional. Diário Oficial da República Federativa do Brasil, Poder Executivo, Brasília, DF, 23 dez. 1996. Seção I, p. 27.839.

-Relatórios técnicos

BRASIL. Ministério da Saúde. Ministério da Educação. Referencial curricular para curso técnico de agente comunitário de saúde. Brasília: Ministério da Saúde, 2004. 64 p. (Série A. Normas e manuais técnicos)

-Relatório final ou de atividades

BRASIL. Ministério da Saúde. Relatório final das atividades. Rio de Janeiro: Fundação Oswaldo Cruz, 1999.

-Jornal

a. Sem indicação de autoria: O GLOBO. Fórum de debates discute o projeto Educando o Cidadão do Futuro. O Globo, Rio de Janeiro, 6 jul. 2001. Caderno 1, p. 18.

b. Com autoria: TOURAINE, Alain. Uma resistência possível. Folha de S. Paulo, São Paulo, 3 jul. 2001. Mais, Caderno 7, p. 18-20.

-Internet 
a. Texto em periódico eletrônico: AZZARÀ, Stefano G. Crítica ao liberalismo, reconstrução do materialismo. Entrevista com Domenico Losurdo. Crítica Marxista, Campinas, n. 35, p. 157-169, 2012. Disponível em: $<w w w . i f c h . u n i c a m p . b r / c r i t i c a m a r x i s t a / a r q u i v o s \_b i b l i o t e c a / e n t r e v i s t a 19 E n t r e v i s t a$ .pdf>. Acesso em 7 out. 2013.

b. Texto em jornal eletrônico: NUBLAT, Johanna. $38,7 \%$ dos usuários de crack das capitais do país estão no Nordeste. Folha de S. Paulo, Seção Cotidiano, São Paulo, 19 set. 2013. Disponível em: $<w w w 1$.folha.uol.com.br/cotidiano/2013/09/1344256-40-dos-usuarios-de-crackdas-capitais-do-pais-estao-no-nordeste.shtml>. Acesso em: 27 set. 2013. c. Texto disponível (fora de revista ou jornal): BRASIL. Ministério da Educação. Portal Educação. Educação profissional: referenciais curriculares nacionais da educação profissional de nível técnico - área Saúde. Disponível em: $<$ http://portal.mec.gov.br/setec/arquivos/pdf/saude.pdf>. Acesso em: 3 out. 2013.

c. Texto disponível (fora de revista ou jornal): BRASIL. Ministério da Educação. Portal Educação. Educação profissional: referenciais curriculares nacionais da educação profissional de nível técnico - área Saúde. Disponível em: <http://portal.mec.gov.br/setec/arquivos/pdf/saude.pdf>. Acesso em: 3 out. 2013.

\section{Revisão}

A revista se reserva o direito de sugerir alterações em usos informais da língua e de corrigir variantes não padrão do português.

\section{Avaliação}

As contribuições encaminhadas à revista são, primeiramente, avaliadas pelos editores, que julgam a adequação temática do texto à linha editorial da publicação e, posteriormente, por até três pareceristas ad hoc. Nomes dos autores e avaliadores de cada original são de conhecimento exclusivo dos editores. Os originais apresentados à Trabalho, Educação e Saúde não devem 
ter sido publicados e não devem ser submetidos simultaneamente a outra revista. Originais submetidos à revista não devem, sob hipótese alguma, ser retirados depois de iniciado o processo de avaliação.

\section{Direitos autorais}

Exceto nos casos em que está indicado o contrário, ficam concedidos à revista os direitos autorais referentes aos trabalhos publicados. Quando da aprovação do manuscrito, os autores deverão assinar um termo de cessão de direitos autorais à revista. Os artigos não podem ser reproduzidos, sem a autorização expressa dos editores, em forma idêntica, resumida ou modificada, em português ou qualquer outro idioma. Os colaboradores manterão o direito de reutilizar o material publicado em futuras coletâneas de sua obra sem o pagamento de taxas à revista. A permissão para reedição ou tradução por terceiros do material publicado não será feita sem o consentimento do autor. Os textos assinados são de responsabilidade dos autores.

\section{Benefício dos autores}

Após a publicação, os autores recebem dois exemplares do número da revista no qual o texto foi publicado.

\section{Submissão de manuscritos}

Os manuscritos devem ser submetidos pelo sistema de avaliação de manuscritos da Revista, disponível na página: <www.revista.epsjv.fiocruz.br>. Primeiramente, o autor principal deve cadastrar-se no sistema e depois cadastrar o manuscrito. Solicitamos aos autores que observem e sigam as instruções para apresentação do manuscrito.

Para informações adicionais, consultar os editores:

<revtes@fiocruz.br>

Aceita-se permuta. 